\title{
Accelerin : the activated form(s) of human blood coagulation factor $\mathrm{V}$
}

Citation for published version (APA):

Bakker, H. M. (1994). Accelerin : the activated form(s) of human blood coagulation factor V. [Doctoral Thesis, Maastricht University]. Rijksuniversiteit Limburg. https://doi.org/10.26481/dis.19940617hb

Document status and date:

Published: 01/01/1994

DOI:

10.26481/dis.19940617hb

Document Version:

Publisher's PDF, also known as Version of record

\section{Please check the document version of this publication:}

- A submitted manuscript is the version of the article upon submission and before peer-review. There can be important differences between the submitted version and the official published version of record.

People interested in the research are advised to contact the author for the final version of the publication, or visit the DOI to the publisher's website.

- The final author version and the galley proof are versions of the publication after peer review.

- The final published version features the final layout of the paper including the volume, issue and page numbers.

Link to publication

\footnotetext{
General rights rights.

- You may freely distribute the URL identifying the publication in the public portal. please follow below link for the End User Agreement:

www.umlib.nl/taverne-license

Take down policy

If you believe that this document breaches copyright please contact us at:

repository@maastrichtuniversity.nl

providing details and we will investigate your claim.
}

Copyright and moral rights for the publications made accessible in the public portal are retained by the authors and/or other copyright owners and it is a condition of accessing publications that users recognise and abide by the legal requirements associated with these

- Users may download and print one copy of any publication from the public portal for the purpose of private study or research.

- You may not further distribute the material or use it for any profit-making activity or commercial gain

If the publication is distributed under the terms of Article $25 \mathrm{fa}$ of the Dutch Copyright Act, indicated by the "Taverne" license above, 


\section{Accelerin}

The activated form(s) of human

blood coagulation factor $\mathrm{V}$

Harry M. Bakker 
CIP-DATA KONINKLIJKE BIBLIOTHEEK, DEN HAAG

Bakker, Harm Marten

Accelerin : the activated form(s) of human blood

coagulation factor V / Harm Marten Bakker. - [S.I. : s.n.]

. - III.

Thesis Maastricht. - With ref. - With summary in Dutch.

ISBN 90-9007257-8

NUGI 743

Subject headings: blood coagulation / Activated Protein C I factor $\mathrm{Va}$. 


\title{
Accelerin
}

\section{The activated form(s) of human}

\section{blood coagulation factor $\mathrm{V}$}

PROEFSCHRIFT

\author{
ter verkrijging van de graad van doctor \\ aan de Rijksuniversiteit Limburg te Maastricht, \\ op gezag van de Rector Magnificus, Prof. Dr. H. Philipsen, \\ volgens het besluit van het College van Dekanen, \\ in het openbaar te verdedigen op vrijdag, 17 juni 1994 \\ om 14.00 uur
}

door

\section{Harm Marten Bakker}




\author{
Promotor Prof. Dr. H.C. Hemker \\ Co-promotores $\quad$ Dr. G. Tans \\ Dr. J. Rosing
}

Beoordelingscommissie Prof. Dr. J.P.M. Geraedts, voorzitter

Dr. K. Hamulyak

Prof. Dr. H. Kuipers

Prof. Dr. P.M. Mannucci, University of Milano

Dr. J.M. van Mourik, CLB, Amsterdam

Financial support by the Netherlands Heart Foundation for the publication of this thesis is gratefully acknowledged. 
Aan mijn ouders

voor Marijke. Jeroen en Maarten 



\section{CONTENTS}

Chapter 1

Chapter 2

Chapter 3

Chapter 4

Chapter 5

Chapter 6

Chapter 7
Introduction

9

Purification of factor $\mathrm{V}$ and $\mathrm{Va}$ venom of Agkistrodon halys halys

Based on: HM Bakker, G Tans, LY Yukelson, TW Janssen-Claessen, RM Bertina, HC Hemker, and J Rosing (1993) Blood Coagulation and Fibrinolysis 4, 605-614

The effect of phospholipids, calcium ions and protein

$S$ on the rate contstants of human factor Va inactivation by activated human protein $\mathrm{C}$

Based on: HM Bakker, G Tans, T Janssen-Claessen, MCLGD Thomassen, HC Hemker, JH Griffin, and J Rosing, (1992), Eur J Biochem 208, 171-178

Functional properties of human factor $\mathrm{Va}$ lacking the 75 Asp ${ }^{683}-\mathrm{Arg}^{709}$ domain of the heavy chain

HM Bakker, G Tans, MCLGD Thomassen, LY Yukelson, R Ebberink, HC Hemker, and J Rosing (1994) submitted

Characterization of two forms of human factor $\mathrm{Va}$ with different cofactor activities

Based on: J Rosing, HM Bakker, MCLGD Thomassen, HC Hemker; and $\mathrm{G}$ Tans (1993) J Biol Chem 298, 2.1130-2.1136.

Summary and concluding remarks

Samenvatting en Slotopmerkingen

References

Abbreviations and Glossary

Dankwoord

Curriculum vitae 



\section{Chapter 1}

\section{INTRODUCTION}

The basic defence mechanism for preventing the loss of blood involves several cellular and plasma components, as well as physiological effects upon the blood vessels involved. When the wall of a blood vessel is damaged blood is lost to the surroundings. Spontaneous arrest of bleeding by vasoconstriction, can be effective in stopping bleeding from small blood vessels. In larger blood vessels, however, formation of a solid plug derived from blood platelets and fibrin is the most important mechanism in haemostasis. The haemostatic plug is formed initially by aggregation of platelets; later fibrin deposition occurs and the fully formed blood clot contains also red cells and leukocytes within the fibrin meshwork. Blood coagulation is the conversion of the soluble protein fibrinogen into the insoluble protein fibrin, by means of thrombin. The biochemical process that leads to blood coagulation essentially is a series of consecutive activations in which (inactive) zymogens are converted to proteolytic enzymes. Typical of this so-called cascade type of process is the large overall amplification resulting from sequential enzymatic activation which is of at least an order of magnitude at each stage.

The enzymes involved in blood coagulation are circulating in plasma in their zymogen form. The zymogens are converted to active serine proteases by limited proteolysis of one or two peptide bonds when the coagulation cascade is activated. The catalytic domains of the coagulation enzymes are all homologous to trypsin and chymotrypsin and contain the enzyme active site, the 'catalytic triad' typical for serine proteases. Coagulation factors are represented by roman numerals. The activated coagulation factors are designated by addition of lowercase 'a'. Thrombin can be formed via two routes, the intrinsic and the extrinsic pathway. The extrinsic pathway is considered to be important in the initiation of fibrin formation (Davie et al., 1991). The (extrinsic) coagulation cascade is initiated when blood makes contact with tissue factor (TF, Figure 1). Tissue factor is exposed to blood when the layer of endothelial cells (inner lining of blood vessels) is damaged. Extravascular tissue constitutively exposes tissue factor molecules on the cell membranes. Tissue factor complexes factor VII from the blood. Complexed factor VII is autoactivated to its active two chain form, factor VIla (Nakagaki et al., 1991). Factor VIla complexed with tissue factor activates the zymogens factor $\mathrm{X}$ and factor IX. Factor $\mathrm{X}$ is not only 
intrinsic

(contact activation) extrinsic

VIla TlF

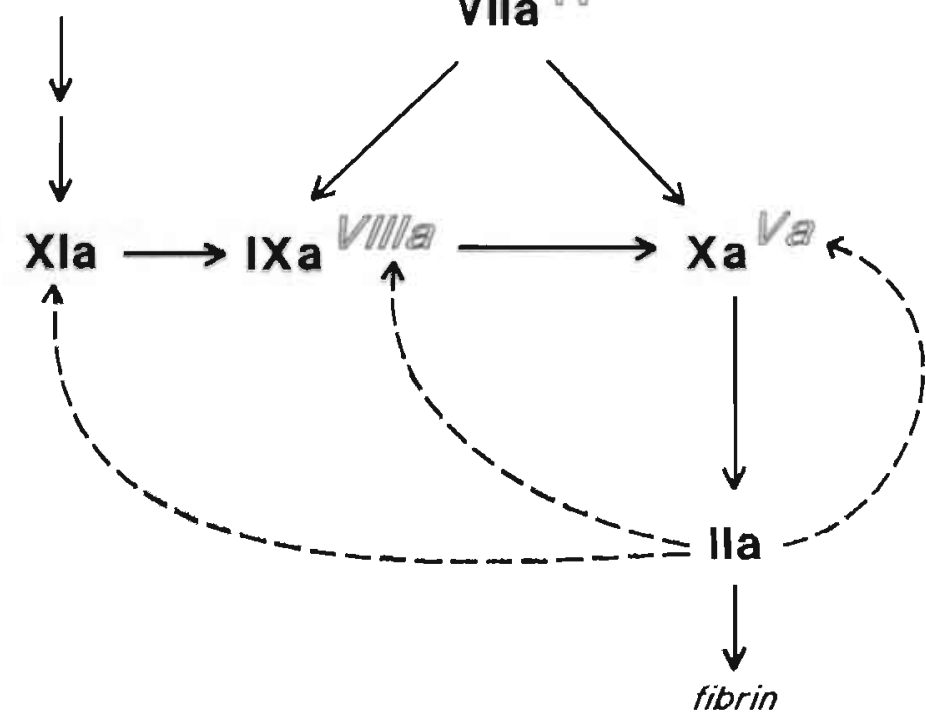

Figure 1. A simplified view of the extrinsic pathway of blood coagulation. When tissue factor (TF) is exposed it binds factor VII, the zymogen factor VII is autocatalytically converted to its active serine protease factor VIla. Factor VIla activates the zyinogens factor IX and X. Factor IXa activates factor $\mathrm{X}$ and represents the major link between the intrinsic and extrinsic pathway. Factor $\mathrm{Xa}$ activates prothrombin into thrombin which converts fibrinogen into insoluble fibrin. Thrombin activates the protein cofactors factor V and VIII (adapted from Hemker and Lindhout, 1984).

activated by VIla-TF complex but also by factor IXa. In 1965, Josso already suggested that factor VIIa-TF complex could activate factor IX, a component of the intrinsic pathway, forming a reinforcement loop for factor Xa generation at low TF concentration (Josso and Prou-Wartelle, 1965; Osterud and Rapaport, 1977). Factor $\mathrm{Xa}$ activates prothrombin (factor II) to thrombin (factor IIa) and thrombin is the enzyme responsible for the conversion of soluble fibrinogen into insoluble fibrin. It is thought that the intrinsic pathway, known as contact activation route, plays a role in sustaining the thrombin generation (Davie et al., 1991). Current data suggest that thrombin produced through the initial action of factor VIIa-TF could activate factor $\mathrm{XI}$ and thereby sustain thrombin generation via the intrinsic pathway (Gailani and 
Broze, 1991). Both pathways converge at factor Xa generation (Figure 1). The function of the cofactors factor V and factor VIII (Figure 1) are discussed below.

The coagulation proteins circulating in plasma are mainly synthesized in the liver. The zymogens prothrombin, factor VII, IX, X and protein $\mathrm{C}$ are posttranslationally modified by the action of a vitamin $\mathrm{K}$-dependent carboxylase (Suttie et al., 1985). Depending which of the coagulation factors is to be carboxylated, 9 to 12 specific Glu residues within the first $45 \mathrm{~N}$-terminal residues are converted to Gla-residues ( $\gamma$-carboxy Glu) by this vitamin-K dependent carboxylase. (Stenflo and Suttie, 1977; Jackson and Nemerson, 1980).

An important feature of coagulation is the fact that the reactions are confined to membrane surfaces. The membrane surfaces that support the coagulation reactions must contain anionic phospholipids. These negatively charged membranes are provided by activated blood platelets and disrupted endothelial cell membranes. The above mentioned Gla residues are required for binding of the vitamin K-dependent clotting factors to negatively charged (procoagulant) membranes. It remains as yet uncertain whether some of the Gla residues directly bind to membrane surfaces through calcium ion bridges (Resnick and Nelsestuen, 1980; Rosing et al., 1987), or whether metal binding to $\gamma$-carboxyglutamic acid in the Gla domain alters the structure of adjacent domains, exposing a membrane-binding site (Nelsestuen, 1976; Prendergast and Mann, 1977; Borowski et al., 1986; Liebman et al., 1987; Furie and Furie, 1988).

The primary structure of most of the human coagulation proteins has been determined by either amino acid and/or cDNA sequencing techniques and the structure and organization of the genes have been resolved (Yoshitake et al., 1985; Leytus et al., 1986, Friezner and Davie, 1987; O'Hara et al., 1987; Jenny et al., 1987; Furie and Furie, 1988; Cripe et al., 1992; Furie and Furie, 1993).

\section{PROTEIN COFACTORS}

In the expression of activity of the active proteases involved in blood coagulation, cofactors play a certral role (Hemker et al., 1967; Hemker and Kahn, 1967; Rosing er al., 1980; van Dieijen et al., 1981; reviewed by Mann et al., 1988). These cofactors are required for efficient proteolytic activity of the serine proteases of the blood coagulation cascade. The effect of the cofactor on the reaction can be regarded to result of at least three separate effects: 1) An increase in the maximum turnover rate $\left(k_{\text {cat }}\right)$ of the reaction. 2) Localization of the enzyme-cofactor complex to membrane surfaces. 3) Stimulation of the binding of the substrate to the 
membrane bound enzyme-cofactor complex. By virtue of the latter two effects, the cofactor can be conceived as forming a receptor on the membrane both for the serine protease and for the substrate.

Factor $\mathbf{V}$ is a single-chain glycoprotein with a MW of 330,000 Da. In 1950, the term proaccelerin and accelerin, for its activated form, were introduced. In the 1960 's the present name, factor V, was gradually adapted. Factor V has been purified to homogeneity from canine, bovine and human plasma (Nesheim et al., 1979; Esmon 1979; Bolhuis et al., 1979; Dahlback, 1980; Kane and Majerus, 1981; Katzmann et al., 1981; Suzuki et al., 1982). The cDNA sequences for human , and recently, bovine factor $V$ have been determined (Kane and Davie, 1986; Kane et al., 1987; Jenny et al., 1987, Guinto et al., 1992) and from this the amino acid sequences could be deduced. Human factor V contains 2196 amino acid residues (Jenny et al., 1987). Factor V has a domain structure similar to that of factor VIII (Figure 2). The homology between the factor $\mathrm{V}$ domains involved in the cofactor activity, A1, A2, A3, C1 and C2 (see below, Figure 2) is $40 \%$ with its factor VIII counterparts (Church et al., 1984; Jenny et al., 1987). The connecting region, the B domains of factor $\mathrm{V}$ and VIII, share a $14 \%$ amino acid sequence homology (Jenny et al., 1987).

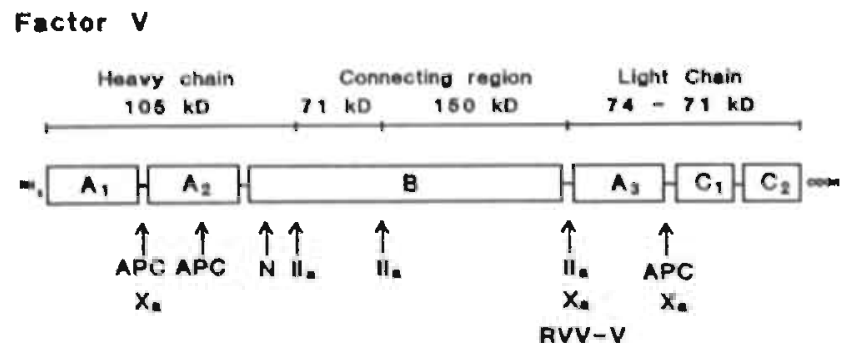

Factor VIII

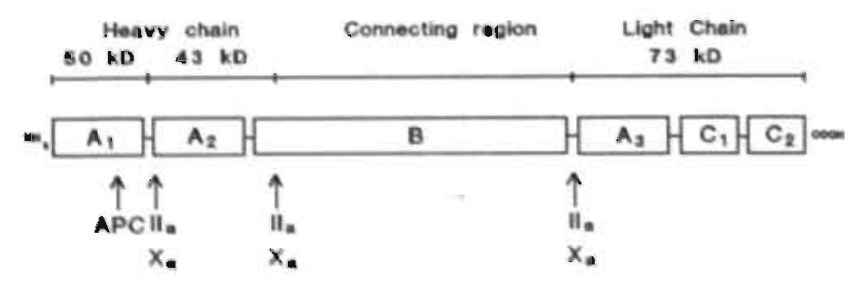

Figure 2. Comparison of the structural domains in factor $\mathrm{V}$ and VIII. Cleavage sites of thrombin, factor $\mathrm{Xa}$, Activated protein $\mathrm{C}$, Russell's viper venom factor $\mathrm{V}$ activator, and platelet associated protease (PAP) are represented by respectively IIa, Xa, APC, RVV-V and N 
Homologies are also found with ceruloplasmin $(\approx 35 \%)$ and discoidin I, the lipid binding lectin from Dictyostelium discoideum (Jenny, 1987). Plasma factor V is synthesized in liver parenchyma cells (Wilson et al., 1984). Platelet $\alpha$-granules (Holmsen and Weiss, 1979) and (aorta) endothelial cells also contain factor V molecules. However, factor V mRNA was not detected in human umbilical vein endothelial cells (Jenny et al., 1987). Factor $\mathrm{V}$ is an inactive procofactor with less than $0.27 \%$ of the activity of the thrombin activated factor V (Nesheim et al., 1979). Thus in order for factor $\mathrm{V}$ to exert its cofactor activity factor $\mathrm{V}$ must be activated during coagulation. That factor $\mathrm{Va}$ is indeed an essential cofactor for prothrombin activation is clear from the data shown in Table 1. Without factor Va the $V_{\max }$ in thrombin formation is far too low to account for coagulation. The mechanism by which factor Va bring about the three factors of magnitude increase in the $V_{\max }$ of thrombin formation is not known. In addition it has been shown that factor $\mathrm{Va}$

Table 1. Kinetic properties of the prothrombinase and tenase complex components. In both cases it is clear that phospholipids (PL) decrease the $K_{\mathrm{m}}$ for the substrate and the cofactor increases the $k_{\text {cat }}$. (Data taken from Rosing et al., 1980; van Dieijen et al., 1981)

\begin{tabular}{lccc}
\hline Component & $\begin{array}{c}K_{\mathrm{m}} \\
(\mu \mathrm{M})\end{array}$ & $\begin{array}{c}V_{\max } \\
\mathrm{mol} \mathrm{Ila}^{-1} \cdot \mathrm{mol} \mathrm{Xa}^{-1}\end{array}$ & $\begin{array}{c}\text { Relative catalytic } \\
\text { Efficiency }\end{array}$ \\
\hline $\mathrm{Xa}$ & 84 & 0.011 & 1 \\
$\mathrm{Xa}, \mathrm{Va}$ & 34 & 6.22 & 1,400 \\
$\mathrm{Xa}, \mathrm{PL}$ & 0.06 & 0.038 & 4,800 \\
$\mathrm{Xa}, \mathrm{Va}, \mathrm{PL}$ & 0.21 & 32.0 & $1,130,000$ \\
\hline
\end{tabular}

$\begin{array}{ccc}K_{\mathrm{m}} & \begin{array}{l}V_{\max } \\ (\mu \mathrm{M})\end{array} & \text { Relative catalytic } \\ \mathrm{mol} \mathrm{Xa}^{-1} \cdot \mathrm{mol} \mathrm{IXa}^{-1} & \text { Efficiency }\end{array}$

\begin{tabular}{lclr}
\hline IXa & 181 & $1.8 \cdot 10^{-4}$ & 1 \\
IXa, PL & 0.058 & $4.1 \cdot 10^{-5}$ & 730 \\
LXa, VIIIa, PL & 0.063 & 8.3 & $140,000,000$ \\
\hline
\end{tabular}


causes a considerable decrease of $K_{\mathrm{m}}$ when prothrombin is activated at procoagulant surfaces with low affinity for prothrombin (Rosing et al., 1980). Prothrombin can be activated to thrombin via two pathways in which prethrombin 2 or meizothrombin occur as reaction intermediate. Factor Va causes a shift in prothrombin activation from a process in which mainly prethrombin 2 and small amounts of thrombin and meizothrombin are produced into one in which only thrombin and meizothrombin are formed (Rosing and Tans, 1988).

In vitro factor $\mathrm{V}$ can be activated by thrombin, factor $\mathrm{Xa}$ and also by proteases isolated from snake venoms (Esmon and Jackson, 1974; Monkovic and Tracy, 1990; Gerads et al., 1992). The most important physiological activator of factor V, however, is most likely thrombin (Pieters et al., 1989). The structure of the activated factor $\mathrm{V}$ is different with various activators. Thrombin activates factor $\mathrm{V}$ via hydrolysis of three peptide bonds. In the human system the first cleavage occur between $\mathrm{Arg}^{709}$ and $\mathrm{Ser}^{710}$, subsequently peptide bonds between $\mathrm{Arg}^{1018}$ / $\mathrm{Thr}^{1019}$ and Arg 1545 / Ser 1546 are cleaved. Partially cleaved factor V already possesses full cofactor activity (Monkovic and Tracy, 1990). Fully thrombin activated factor V consists of a $105 \mathrm{kD}$ heavy chain and a 71 and $74 \mathrm{kD}$ light chain doublet which are noncovalently associated through interactions that involve a single calcium ion (Nesheim and Mann, 1979; Esmon, 1979; Guinto and Esmon, 1982). Russell's viper (Vipera misselli) venom (RVV-V) activated factor V is cleaved between $\operatorname{Arg}^{1545}$ and Ser ${ }^{1546}$ resulting in a large heavy chain and a light chain similar to the thrombin activated factor V (Suzuki et al., 1982; Dahlback, 1986; see Figure 2). This suggests that a single cleavage within the $\mathrm{B}$ region will bring the $\mathrm{N}$ - and $\mathrm{C}$-terminal parts of the factor $\mathrm{V}$ molecule together resulting in an active cofactor molecule (Dahlback, 1986). It has been generally accepted that the factor Va heavy chain is mainly responsible for the cofactor activity. The heavy chain contains a binding region for prothrombin (Guinto and Esmon, 1984) and the light chain is involved in the interaction with membrane surfaces. Both heavy and light chain are required for binding to factor Xa (Guinto and Esmon, 1984). The location of the lipid binding site on the factor Va light chain is a matter of controversy. In bovine factor Va, the lipid binding site has been localized in the A3 domain to the amino acid residues 1667-1765 (Kalafatis et al., 1990). Analysis of deletion mutants of recombinant human factor $\mathrm{V}$ showed that only deletion of the $\mathrm{C} 2$ domain resulted in a considerable loss of the phospholipid binding properties of factor Va (Ortel et al., 1992). 
Factor VIII is a single-chain glycoprotein of $265,000 \mathrm{Da}$, which shows marked sequence homology with factor $\mathrm{V}$ and ceruloplasmin (Church et al., 1984; Jenny et al., 1987; see above). In plasma factor VIII circulates in complex with the carrier protein, von Willebrand factor (Hoyer, 1981). Factor VIII has been purified from human, porcine and bovine plasma. The cDNA sequence for factor VIII has been determined (Vehar et al., 1984; Toole et al., 1984). This cDNA codes for a peptide of 2332 amino acid residues. In order to exert its cofactor function, factor VIII must also be activated during coagulation. Factor VIIIa can be produced through limited proteolysis by thrombin or factor Xa (Figure 2). Factor VIIla exerts effects in factor IXa-catalyzed factor $\mathrm{X}$ activation similar to the effects of factor $\mathrm{Va}$ in prothrombin activation. Bound to the membrane surface, factor VIIIa enhances the assembly of factor IXa into the tenase (IXa-VIIIa) complex, and factor VIIIa increase the $k_{\text {cat }}$ of Xa formation (van Dieijen et al., 1981; Griffith et al., 1982; van Dieijen et al., 1985; Table 1).

Tissue factor, is an integral membrane protein expressed on the surface of subendothelial cells. It is a $53 \mathrm{kDa}$ glycoprotein, rich in carbohydrates (Broze et al., 1985; Guha et al., 1986). In contrast to factors V and VIII, tissue factor needs not to be activated in order to perform its function. Tissue factor has no proteolytic activity and is thought to serve as a receptor for factor VII. It was recently shown that the single-chain zymogen, factor VII is converted to two-chain factor VIla in an autocatalytic manner following complex formation with tissue factor (Nakagaki $e t$ al., 1991; Yamamoto et al., 1992). The complexed factor VIIa activates factor $\mathrm{X}$ (Nemerson, 1988; Gemmel et al., 1988) and factor IX (Østerud and Rapaport, 1977).

\section{MEMBRANE SURFACE}

Catalysis of reactions at membrane surfaces is a characteristic feature of the coagulation cascade (Rosing and Tans, 1988; Mann et al., 1990). A suitable membrane surface is a surface containing negatively charged phospholipids (i.e. phosphatidylserine). These surfaces are provided by activated platelets and disrupted endothelial cells. The presence of membranes profoundly changes the kinetic parameters of coagulation factor activations and inactivations (see Table 1 ). The $K_{\mathrm{m}}$ for the substrate is greatly decreased in the presence of phospholipid membranes and appears to be a function of the phospholipid concentration present in the reaction medium. When the concentration of phospholipid is increased there is a parallel 
increase of the $K_{\mathrm{m}}$ which is explained by the fact that the membrane-bound substrate molecules are diluted or bind to non-functional sites due to the increased amount of surface. Also the $V_{\max }$ of phospholipid-dependent reactions often appears to be a function of the phospholipid concentration. In general, the $V_{\max }$ increases with the amount of phospholipid present and reaches a maximum at high phospholipid concentrations. The lipid dependency of $V_{\max }$ is a reflection of the binding of the enzyme to the membrane surface which increases at increasing surface concentration until at high surface concentration all enzyme is bound and participates in coagulation enzymatic reactions. Another aspect of membranes is the receptor function of cofactors. All coagulation proteins bind to negatively charged membrane surfaces. The cofactors factor Va and factor VIIla have relatively low dissociation constants (in the order of $0.1 \mathrm{nM}$; Pusey et al., 1982; Kop et al., 1989; Andree, 1992), thus tend to bind with relatively high affinity. The vitamin K-dependent zymogens have dissociation constants 2 to 4 orders of magnitude higher, which suggest a 'receptor' function for the activated cofactors. Furthermore membrane bound molecules have an increasing probability of collision. Activated cofactors bound to a membrane, therefore can assemble faster with the appropriate enzyme. Enzyme(complex) and substrate also have a higher probability of collision. A probability of collision between reacting molecules in two dimensional space, as on a membrane surface, is one to two orders of magnitude greater than in three dimensional space (Berg and von Hippel, 1985; Giesen, 1992).

\section{PLATELETS}

Platelets play a major role in the initiation of the hemostatic process in vivo. Several receptors on its surface enable it to interact with components of the subendothelial matrix that become exposed when the vascular endothelium is damaged (e.g. collagen). Upon adhesion a sequence of metabolic events is triggered that cause platelets to aggregate into clumps sealing the damaged vessel. During this process, secretion of substances amplifying aggregation and blood coagulation occurs.

Platelets are non-nucleated discoid cells, $2-5 \mu \mathrm{m}$ in diameter which originate from budding of giant polyploid megakaryocytes residing in the bone marrow. Immediately following adherence, the platelet changes shape from a discoid structure to a sphere with projecting pseudopodia, which interact with other platelets. Finaliy, flattening and discharge of the cytoplasmic granules occur, with the release of ATP, ADP, calcium, platelet factor 4 (PF4), fibrinogen, factor $\mathrm{V}$, and 
protein S (cofactor of protein C; see below), many of which amplify the aggregation process by causing other platelets to aggregate. Unactivated platelets show an asymmetric membrane composition with negatively charged phospholipids (i.e. phosphatidylserine) located inside. Upon activation the phospholipids in the membrane become scrambled. The exposed phosphatidylserine in the activated platelet membrane provide an excellent surface for the coagulation cofactors $\mathrm{Va}$ and VIIIa, and the assembly of prothrombinase and tenase complexes responsible for activation of prothrombin and factor $\mathrm{X}$ respectively. These surfaces also support the anticoagulant protein $\mathrm{C}$ pathway (see below).

\section{ENDOTHELIAL VESSEL WALL}

In health, there is a balance between the clot inhibiting and clot promoting activities of the endothelium so that detrimental intravascular clotting is prevented. Endothelial production of prostacyclin $\left(\mathrm{PGI}_{2}\right)$ prevents the aggregation of any adhering platelets. Endothelial cells constitutively express thrombomodulin at the cell surface and this thrombomodulin complexes with thrombin if any thrombin should form. Thrombin complexed with thrombomodulin loses its procoagulant properties (i.e. cleavage of fibrinogen, stimulation of platelets and activation of the factors $\mathrm{V}$ and $\mathrm{VIII}$ ) and gains anticoagulant properties (activation of protein $\mathrm{C}$ ). Activated protein $\mathrm{C}$ (APC) inactivates any activated factor $\mathrm{V}$ or factor VIII. The APC-mediated inactivation of factor Va and VIIIa on endothelial cells is accelerated by protein $\mathrm{S}$. Endothelial cells also possess heparin-like molecules on their surface. These molecules act as binding sites for antithrombin III (ATIII) which inhibits especially thrombin and factor $\mathrm{Xa}$. All these properties of endothelium help to prevent local thrombus formation. Endothelial cells can, however, also actively promote blood coagulation. This only occurs if there is some 'stress' to the endothelium, but it does not necessarily require endothelial cell disruption or death. If, for instance, endothelial cells are exposed to endotoxin or tumor necrosis factor (TNF), they actively produce tissue factor molecules which promote clotting activity via factor VII binding (extrinsic pathway). In addition, thrombomodulin is internalized. Also prostacyclin production may drop after serious endothelial stress, platelets may adhere and aggregate releasing platelet factor IV, which is an antiheparin and prevents (local) ATIII activity. The balance of clot preventing and promoting activities is in favor of clot prevention by a fully healthy and non-stressed endothelium. 


\section{CONTROL OF COAGULATION}

Clearly, uncontrolled coagulation would be fatal, therefore, modulating mechanisms exist to control and limit intravascular coagulation. Twoo systems control coagulation. One of the systems involves the presence of serine protease inhibitors (serpins) in plasma (see Table 2). These proteins inactivate serine proteases by acting as a suicide substrate. The other system is the protein $\mathrm{C}$ pathway. The protein $\mathrm{C}$ pathway, involving activated protein $\mathrm{C}$ and its cofactor protein $\mathrm{S}$, attenuate the activity of the coagulation pathway by the selective inactivation of factors Va and VIIIa (Esmon, 1984).

\section{SERPINS}

Table 2 summarizes the most important protease inhibitors characterized from human plasma. Antithrombin III appears to be the most significant inhibitor of the coagulation process (Travis and Salvesen, 1983). Antithrombin III reacts mainly with thrombin and factor $\mathrm{Xa}$. It functions by acting as a substrate for the serine protease forming an irreversible complex with the protease and its function is considerably enhanced in the presence of heparin. Inhibition of the factor $\mathrm{Xa}$ /factor VIla/tissue factor complex involves a plasma inhibitor named tissue factor pathway inhibitor (TFPI) (Rao and Rapaport, 1987; Broze, 1987; Rapaport, 1989). In addition, other inhibitors of the proteases in the coagulation cascade are found, i.e. $\alpha 2$-macroglobulin, $\alpha 2$-antiplasmin and $\mathrm{Cl}$ inhibitor (Travis and Salvesen, 1983).

Table 2. Properties of the major serine protease inhibitors (serpins) in plasma. Data taken from Travis J, and Salvesen GS, 1983; Tollfsen DM et al., 1982; Heeb MJ et al., 1989; Novotny WF et al., 1989; Rapaport SI, 1991.

\begin{tabular}{lccl}
\hline Serine protease inhibitors & $\begin{array}{c}\text { Molecular } \\
\text { weight }\end{array}$ & $\begin{array}{c}\text { Plasma } \\
\text { concentration } \\
(\mu \mathrm{M})\end{array}$ & Enzymes inhibited \\
\hline Antithrombin II & 58000 & 2 & Thrombin, Xa \\
Cl inhibitot & 105000 & 2 & C1, Kallikrein \\
$\alpha_{2}$ Macroglobulin & 725000 & 3.5 & Thrombin, kallikrein \\
$\alpha_{1}$ Antitrypsin & 55000 & 25 & XIa, APC \\
$\alpha_{2}$ Antiplasmin & 67000 & 1 & Plasmin \\
Heparin cofactor II & 66000 & 1 & Thrombin, Xa \\
TFPI & 33000 & 0.0025 & TF/VIa/Xa-complex \\
PCI & 57000 & 0.010 & APC, XIa \\
\hline
\end{tabular}




\section{PROTEIN C PATHWAY}

Already in 1960, Seegers and coworkers described an inhibitor of blood coagulation thought to be derived from prothrombin and named it autoprothrombin II-A (Mammen et al., 1960). In 1976, protein C was purified from bovine plasma (Stenflo, 1976) and was shown to be the zymogen of autoprothrombin II-A (Seegers et al., 1976). Protein C is activated by thrombin when complexed with an endothelial cell membrane protein, thrombomodulin (Esmon ef al., 1982). It exerts its regulatory function by inactivating factors $\mathrm{Va}$ and VIIIa. The inactivation of these factors is accelerated by a protein cofactor for activated protein $\mathrm{C}$, protein $\mathrm{S}$ (Walker, 1980). In recent years, however, doubt has arisen as to the cofactor function of protein S (see also below) and, recently, Dahlbăck et al. (1993) have provided evidence for the existence of another as yet unidentified cofactor for activated protein $\mathrm{C}$.

The activated protein $\mathrm{C}$ pathway is regulated by an inhibitor of activated protein C (PCI) which has been demonstrated in plasma (Marlar and Griffin, 1980). This inhibitor forms heparin-dependent complexes with activated protein $\mathrm{C}$ when tested in a purified system (Suzuki et al., 1984). Human activated protein $C$ is also inhibited by al-antitrypsin (Heeb and Griffin, 1988; Heeb et al., 1989). Both protein $\mathrm{C}$ inhibitors seem to be of physiological importance in vivo (Heeb and Griffin, 1988).

Protein $\mathbf{C}$ is a multidomain glycoprotein circulating in plasma as a precursor of a serine protease. Human protein $C$ has an apparent molecular weight of 62,000 $\mathrm{Da}$ and a carbohydrate content of approximately $23 \%$ (Kisiel, 1979). The concentration of human protein $C$ in plasma is approximately $65 \mathrm{nM}$ (Comp et al., 1984; Sala et al., 1984; Seligsohn et al., 1984; Ikeda and Stenflo, 1985). Protein C has been purified from bovine and human plasma (Stenflo, 1976; Kisiel, 1979). The primary structure of human protein $\mathrm{C}$ was determined from the cDNA sequencing (Foster and Davie, 1984). In addition, the structure of the gene for human protein C has been determined (Foster et al., 1985). Like the other vitamin K-dependent proteins, protein C is synthesized in the liver (Fair and Marlar, 1986).

As for the other vitamin K-dependent Gla-containing blood coagulation proteins, it has been shown that bovine protein $\mathrm{C}$ is capable of interaction with $\mathrm{Ca}^{2+}$ (Stenflo, 1976). It has been found that protein $\mathrm{C}$ with the Gla domain removed by limited proteolysis is much slower activated by thrombin bound to thrombomodulin on the surface of endothelial cells than is intact protein C (Esmon et al., 1983). An 
intact Gla domain is thus required for normal activation of protein $\mathrm{C}$ on cell surfaces, as well as for the protein to exert its anticoagulant function.

The anticoagulant effect of activated protein $\mathrm{C}$ has been described by several investigators (Marciniak, 1970; Kisiel et al., 1977; Walker et al., 1979; Seegers, 1981). Activated protein $C$ has a narrow substrate specificity and exerts its anticoagulant effect by selectively inactivating factors Va and VIIIa (Kisiel et al., 1977; Vehar and Davie, 1980). Factor Va and factor VIIIa degradation have been studied in detail (Kisiel et al., 1977; Vehar and Davie, 1980; Marlar et al., 1982; Suzuki et al., 1983; Fulcher et al., 1984; Odegaard and Mann, 1987; Chapter 5). Figure 2 shows the cleavage sites of activated protein $C$ in the cofactors $\mathrm{Va}$ and VIIIa. Activated protein $\mathrm{C}$ inactivates factor $\mathrm{Va}$ by proteolytic cleavages in both chains of factor Va. The heavy-chain cleavages are probably the important ones in destroying the cofactor activity (Odegaard and Mann, 1987). Bovine factor Va inactivated by activated protein $\mathrm{C}$ loses its ability to bind to prothrombin and factor Xa (Guinto and Esmon, 1984). Cleavage of the Va light chain by APC in the bovine system is appears to be much faster than in the human system.

Protein S is thought to act as a cofactor in the APC-catalyzed degradation of the factors Va and VIIIa (Walker, 1980; Walker et al., 1987; Heeb and Griffin, 1988; Koedam et al., 1988). The physiological significance of protein $\mathrm{S}$ is demonstrated by the fact that there is a relationship between deficiency of protein $S$ and venous thromboembolism (Briet et al., 1988; Walker, 1992). Protein $S$ is a vitamin $\mathrm{K}$-dependent protein, which is not a zymogen of a serine protease. The primary structure of human protein S has been determined (Lundwall et al., 1986; Hoskins et al., 1987). It has been reported that protein $S$ is absolutely required for activated protein $\mathrm{C}$ to exert its anticoagulant function on the surface of activated bovine platelets (Harris and Esmon, 1985). Binding of protein S to human endothelial cells was reported recently to be required for expression of cofactor activity for activated protein C (Hackeng et al., 1993). On human platelets, however, this absolute requirement has not been shown (Solymoss et al., 1988; Tans et al., 1990). In the past few years data have become available that indicate that protein $\mathrm{S}$ must at least also have other functions in the protein $\mathrm{C}$ pathway in addition to the cofactor function for activated protein C. In vitro experiments, for instance, show that protein $\mathrm{S}$ stimulate the inactivation of factor Va by APC maximally a factor 2 (Solymoss et al., 1988; Tans et al,, 1990; Chapter 5.). Furthermore, factor Xa was shown to protect factor $\mathrm{Va}$ against proteolytic inactivation by activated protein $\mathrm{C}$. Protein $\mathrm{S}$ 
was found to abrogate this protective effect (Nesheim et al., 1982; Jane et al., 1991). Salem and coworkers reported anticoagulant properties of protein $\mathrm{S}$ in the absence of activated protein C (Michell et al., 1988). This suggested a direct interaction between protein $\mathrm{S}$ and the prothrombinase complex. Recently, it was indeed demonstrated that protein $\mathrm{S}$ inhibits the prothrombinase complex via interaction with prothrombinase components (Heeb et al., 1993). 



\section{Chapter 2}

\section{Purification of factor $\mathrm{V}$ and $\mathrm{Va}$}

Factor $\mathrm{V}$ is a single chain plasma glycoprotein that circulates in plasma as an inactive cofactor at a concentration of approximately $8 \mu \mathrm{g} / \mathrm{ml}(\sim 25 \mathrm{nM})$. Factor $\mathrm{V}$ is a rather labile protein and this has complicated the isolation of this factor from plasma for many years. By the end of the seventies, procedures were developed to isolate single chain factor $\mathrm{V}$ from bovine plasma (Nesheim et al., 1979; Esmon 1979). This work opened the way to the isolation of the even more labile human factor V (Bolhuis et al., 1979; Dahlbäck, 1980; Kane and Majerus, 1981; Katzmann et al., 1981; Suzuki et al., 1982). Factor $\mathrm{V}$ is activated by thrombin releasing two activation peptides of 71 and $150 \mathrm{kD}$. Factor $\mathrm{Va}$ is a heterodimer which consists of a $105 \mathrm{kD}$ heavy chain and a $71-74 \mathrm{kD}$ light chain doublet. Guinto and Esmon (1984) have demonstrated that factor $\mathrm{Va}$ separated from factor $\mathrm{V}$ and the activation peptides by affinity chromatography over Prothrombin-Sepharose.

Isolation procedures of human factor $\mathrm{V}$ usually start with adsorption of plasma with bariumsulfate to remove vitamin $\mathrm{K}$ dependent coagulation proteins, this includes removal of prothrombin and factor $\mathrm{X}$ which are precursors of the factor $\mathrm{V}$ activators thrombin and factor Xa. The first step is followed by polyethylene glycol fractionation, ion exchange chromatography on QAE- or DEAE-based columns and gel filtration chromatography. Essential in the procedures is the abundant use of protease inhibitors. Most common is the use of benzamidine in a concentration of 10 $\mathrm{mM}$. Furthermore, soybean trypsin inhibitor (inhibits factor Xa), phenylmethanesulfonyl fluoride (PMSF), and diisopropyl fluorophosphate (DFP) are frequently used. Since these inhibitors also interfere with factor $V$ activation by thrombin or factor Xa they are omitted in the final step or removed fiom the final preparations via dialysis.

The purification procedures in general yield reasonable pure factor $\mathrm{V}$ preparations $(>80-85 \%)$. However, for highly purified factor $\mathrm{V}$ preparations the available procedures are time consuming and result in variable yields and quality of the final material. In this chapter, we describe a factor $V$ and a factor Va purification method that we developed in order to overcome these difficulties. The factor $\mathrm{V}$ purification method we use is based on the procedure developed by Dahlbäck (1980) and Suzuki et al., (1982). Changes made in this procedure resulted in a decrease of the isolation time, in higher yields, higher concentration of factor $\mathrm{V}$ and in much less variability and quality of the final preparation. The factor Va purification method we used is based on the method of Guinto and Esmon (1984). 


\section{EXPERIMENTAL PROCEDURES}

Materials. Bovine serum albumin, chicken egg albumin (ovalbumin), eggyolk PC, bovine brain PS, HEPES and Tris were purchased from Sigma Chemical Co., St. Louis, MO, USA. The chromogenic substrate S2238 and the thrombin inhibitor I-2581 were obtained from AB Kabi Diagnostica, Stockholm, Sweden. PPACK was from Calbiochem, La Jolla Ca. p-NPGB was purchased from Nutritional Biochemicals.

Proteins. Proteins used in this study were purified from fresh frozen human plasma. Prothrombin was purified according to DiScipio et al., (1977). Thrombin was isolated from prothrombin activation mixtures in which purified prothrombin (20 mg) was activated at $37^{\circ} \mathrm{C}$ in $10 \mathrm{ml}$ of a buffer solution containing $50 \mathrm{mM}$ Tris (pH 7.5 at $37^{\circ} \mathrm{C}$ ), $100 \mathrm{mM} \mathrm{NaCl}, 2 \mathrm{mM} \mathrm{CaCl}_{2}, 50 \mu \mathrm{M}$ phospholipid vesicles (brain PS/egg-yolk PC; $20 / 80, \mathrm{~mol} / \mathrm{mol}), 2.5 \mathrm{nM}$ factor Xa, $40 \mathrm{nM}$ factor Va and $20 \mu \mathrm{M} \mathrm{I}$ 2581. The reversible thrombin inhibitor I-2581 was present to prevent autocatalytic degradation of thrombin. Prothrombin activation was complete within $10 \mathrm{~min}$ after which the thrombin was purified from the reaction mixture as described by Pletcher and Nelsestuen (1982). Bovine factor Xa, which was used in the factor Va assay (see below), was purified as described by Fujikawa et al., (1972). RVV-X was purified from the crude venom of Russell's viper by the method of Schiffman et al., (1969). Protein preparations were homogeneous and $>95 \%$ pure as judged by polyacrylamide gel electrophoresis in the presence of sodium dodecyl sulfate according to Laemmli (1970).

Protein concentrations. Protein concentrations were routinely determined according to Lowry et al., (1951) using BSA as a standard. Molar concentrations of thrombin and factor Xa were determined by active site titration with p-NPGB (Chase and Shaw, 1969; Smith, 1973). Concentrations of factor Va were determined kinetically as described for bovine factor Va by Lindhout et al., (1982).

Phospholipid vesicle preparations. The phospholipid vesicles used in the factor Va assay were prepared from a mixture of 10 mole $\%$ brain-PS and 90 mole $\%$ egg PC. Vesicles were made by mixing the desired quantities of lipids, dissolved in $\mathrm{CHCl}_{3} / \mathrm{CH}_{3} \mathrm{OH}(1 / 1, v / v)$, in a glass test tube. After drying under mild $\mathrm{N}_{2}$ flow, buffer containing $50 \mathrm{mM}$ Tris- $\mathrm{HCl}\left(\mathrm{pH} 7.9\right.$ at $\left.20^{\circ} \mathrm{C}\right)$ and $175 \mathrm{mM} \mathrm{NaCl}$ was added. After vigorous vortexing for 1 minute the formed liposomes were sonicated for 10 minutes at $4{ }^{\circ} \mathrm{C}$ using a MSE Mark II 150-W ultrasonic disintegrator set at $8 \mu \mathrm{m}$ peak to peak amplitude. These vesicles were stored at $-80^{\circ} \mathrm{C}$ prior to use. 
Preparation of Prothrombin-Sepharose. Bovine prothrombin $(100 \mathrm{ml}, 1$ $\mathrm{mg} / \mathrm{ml}$ ) in buffer containing $0.1 \mathrm{M} \mathrm{NaHCO}_{3} \mathrm{pH} 9.0$ and $0.5 \mathrm{M} \mathrm{NaCl}$ was coupled overnight at $4{ }^{\circ} \mathrm{C}$ to $4 \mathrm{~g} \mathrm{CNBr}$-activated Sepharose $4 \mathrm{~B}$. After several washing steps with alternating $1 \mathrm{M}$ Ethanolamine $\mathrm{pH} 8.0$ and $0.1 \mathrm{M} \mathrm{Na}$-acetate buffer $\mathrm{pH} 5.0,1 \mathrm{M}$ $\mathrm{NaCl}$, the gel was stored in $25 \mathrm{mM}$ HEPES pH 7.5, $50 \mathrm{mM} \mathrm{NaCl}$ and $0.02 \% \mathrm{Na}$ azide. The final concentration on the gel was $6.5 \mathrm{mg}$ prothrombin/ml gel. The efficiency of coupling was $97 \%$.

Isolation of Human factor $\mathrm{V}$. Factor $\mathrm{V}$ was purified by modification of the procedure as described by Dahlbäck (1980) and Suzuki et al., (1982). Only plastic labware was used throughout the whole procedure. All buffer solutions used in the isolation procedure contained the irreversible thrombin inhibitor PPACK. The gel permeation chromatography on FPLC Superdex-200 was performed with a buffer solution that did not contain PPACK. The presence of PPACK was necessary to obtain reproducible preparations of homogeneous and single chain factor $\mathrm{V}$ (Factor Va was stable for several months at $-80^{\circ} \mathrm{C}$ and lost about $10 \%$ of its activity when kept on ice for 6 hours). The purification is essentially as follows: Six units fresh frozen citrate plasma (approximately 1.5 litre) were rapidly thawed in warm water while gently shaking and benzamidine, STI (Soybean Trypsin Inhibitor), and PPACK were added to a final concentration of $10 \mathrm{mM}, 50 \mathrm{mg} / \mathrm{l}$, and $2 \mu \mathrm{M}$ respectively. The inhibitors were allowed to dissolve and react with proteases for ten minutes after which the mixture was transferred to $4{ }^{\circ} \mathrm{C}$. All further steps were performed in the cold room at $4{ }^{\circ} \mathrm{C}$. A $1 \mathrm{M} \mathrm{BaCl}_{2}$ solution was added dropwise to the plasma to result in a final concentration of $74 \mathrm{mM} \mathrm{BaCl}_{2}$ while stiring with a magnet bar. After 30 minutes the barium-citrate precipitate was removed by centrifugation for 10 minutes at $1250 * \mathrm{~g}$. The supernatant was brought to $7 \%$ polyethylene glycol 6000 by adding dropwise $250 \mathrm{ml}$ of a $50 \%$ stock solution. The precipitate was removed by centrifugation ( 15 minutes at $3600 * \mathrm{~g}$ ) after which the supernatant was brought to $13 \%$ polyethylene glycol by adding dropwise $240 \mathrm{ml}$ of the $50 \%$ stock solution. The formed precipitate contained the factor $\mathrm{V}$. The mixture was stirred for 60 minutes and centrifuged for 15 minutes at $3600 * \mathrm{~g}$ and the supernatant was carefully discarded. The precipitate was dissolved in $350 \mathrm{ml}$ DEAEstart buffer containing $20 \mathrm{mM}$ Tris- $\mathrm{HCl}\left(\mathrm{pH} 7.5\right.$ at $\left.4{ }^{\circ} \mathrm{C}\right), 50 \mathrm{mM} \mathrm{NaCl}, 5 \mathrm{mM}$ $\mathrm{CaCl}_{2}, 10 \mathrm{mM}$ benzamidine and $2 \mu \mathrm{M}$ PPACK. The dissolved precipitate was centrifuged at $3600 * \mathrm{~g}$ to remove all non-soluble particles and was loaded overnight on a DEAE-sepharose-CL-6B column $(1.5 * 30 \mathrm{~cm})$ equilibrated in DEAE-start buffer. After loading the column was rinsed with the same buffer containing 120 
$\mathrm{mM} \mathrm{NaCl}$ and $0.25 \mu \mathrm{M}$ PPACK until the $\mathrm{A}_{280}$ in the effluent had reached approximately the buffer value. The column was developed with a $300 \mathrm{ml}$ linear gradient from $120 \mathrm{mM} \mathrm{NaCl}$ to $250 \mathrm{mM} \mathrm{NaCl}$. Fractions of $6 \mathrm{ml}$ were collected and screened for factor $\mathrm{V}$ cofactor activity (see below). Fractions with factor $\mathrm{V}$ activity were pooled. Solid ammonium sulphate was slowly added to the pooled fractions to a final amount of $70 \%$. The ammonium sulphate precipitate was stirred for 1 hour, spun down for 15 minutes at $25000 * \mathrm{~g}$ and dissolved in a small volume $(2-3 \mathrm{ml})$ of HEPES buffer containing $10 \mathrm{mM}$ HEPES pH 7.5, $50 \mathrm{mM} \mathrm{NaCl}$. The dissolved ammonium sulphate precipitate was centrifuged for 15 minutes at $14000 * \mathrm{~g}$ to remove insoluble material before loading on a FPLC Superdex-200 (16/60) column. The column was equilibrated and developed in HEPES buffer without PPACK or other protease inhibitors. Fractions of $1.0 \mathrm{ml}$ were collected and tested for factor $\mathrm{V}$ activity. The fractions containing factor $\mathrm{V}$ activity were pooled and stored in alicuots at $-80^{\circ} \mathrm{C}$.

Factor $\mathrm{V}$ preparations thus obtained were $\geq 85 \%$ pure and single chain as judged by SDS-PAGE. Contaminations varied from preparation to preparation between $5 \%$ $15 \%$ (the most abundant contamination being a small protein running in the buffer front of a Laemmli SDS gel).

Chromalography of factor $V$ on $M$ Mno $S^{\circledR}$. Factor $V$ was chromatographed on a FPLC MonoS ${ }^{\circledast}$ column equilibrated with $25 \mathrm{mM}$ HEPES pH 7.5, $50 \mathrm{mM} \mathrm{NH}_{4} \mathrm{Cl}$ and $5 \mathrm{mM} \mathrm{CaCl}_{2}$. After loading of the factor $\mathrm{V}$ the column was washed with ten column volumes starting buffer. The column was subsequently developed with a 15 $\mathrm{ml}$ linear gradient from $50 \mathrm{mM} \mathrm{NH} \mathrm{N}_{4} \mathrm{Cl}$ to $1 \mathrm{M} \mathrm{NH} \mathrm{NH}_{4} \mathrm{Cl}$. Fractions of $1 \mathrm{ml}$ were collected and screened for factor $\mathrm{V}$ activity (see below). Factor $\mathrm{V}$ preparations thus obtained were pure $(>95 \%$ ) and single chain as judged by SDS-PAGE (see also Figure 4).

Acivation of himan factor $V$. Factor $V a$ was prepared by activation of factor $V$ with $30 \mathrm{nM}$ human thrombin for 30 minutes $10 \mathrm{mM}$ HEPES $\mathrm{pH} 7.5,50 \mathrm{mM}$ $\mathrm{NaCl}$, and $5 \mathrm{mM} \mathrm{CaCl}_{2}$. After activation, $30 \mathrm{nM}$ PPACK was added to inhibit thrombin. Factor $\mathrm{Va}$ was either used as such or further purified by affinity chromatography on Prothrombin-Sepharose. To this end a Prothrombin-Sepharose column $(0.5 * 5 \mathrm{~cm})$ was loaded with thrombin activated factor $\mathrm{V}$. The column was equilibrated and after sample application washed with a buffer containing $25 \mathrm{mM}$ HEPES pH 7.5, $50 \mathrm{mM} \mathrm{NH}_{4} \mathrm{Cl}$ and $5 \mathrm{mM} \mathrm{CaCl}_{2}$. The amount of factor Valoaded on the column ranged between $0.2-1.0 \mathrm{mg}$ factor $\mathrm{Va}$. The column was developed with a $15 \mathrm{ml}$ linear gradient from $50 \mathrm{mM} \mathrm{NH}_{4} \mathrm{Cl}$ to $450 \mathrm{mM} \mathrm{NH} \mathrm{N}_{4} \mathrm{Cl}$. The eluted 
factor Va was used directly or was stored at $-80^{\circ} \mathrm{C}$ after addition of $5 \mathrm{mg} \mathrm{BSA} / \mathrm{mil}$.

Factor $V$ assay. Factor $\mathrm{V}$ was activated by thrombin and assayed for cofactor activity (see below). In a typical experiment factor $\mathrm{V}$ was diluted to a concentration of approximately $1 \mathrm{nM}$ in buffer containing $25 \mathrm{mM}$ HEPES pH 7.5, $126 \mathrm{mM} \mathrm{NaCl}$, $2.68 \mathrm{mM} \mathrm{KCl}, 5 \mathrm{mM} \mathrm{CaCl}_{2}$ and $5 \mathrm{mg} / \mathrm{ml} \mathrm{BSA}$. To $90 \mu \mathrm{l}$ of the diluted factor $\mathrm{V} 10 \mu$ 1 thrombin of a $60 \mathrm{nM}$ stock solution was added. After 10 minutes incubation at $37^{\circ}$ $\mathrm{C}$ an aliquot of $10 \mu \mathrm{l}$ was taken from the mixture and assayed for its factor Va activity (see below).

Factor Va assay. Factor Va was determined via its cofactor activity in the activation of prothrombin by factor $\mathrm{Xa}$. For convenience, bovine factor $\mathrm{Xa}$ was used in the assay. Amounts of factor Xa, phospholipid vesicles and prothrombin present in the assay were such that the rate of prothrombin activation was linearly dependent on factor $\mathrm{Va}$, was constant in time, and was not influenced by small variations of the factor $\mathrm{Xa}$, phospholipid and prothrombin concentrations. In a typical experiment factor Va was quantitated as follows: to $230 \mu$ of a buffer solution (prewarmed at $37{ }^{\circ} \mathrm{C}$ ) containing prothrombin and phospholipid, $10 \mu \mathrm{l}$ bovine factor Xa was added and after $15 \mathrm{~s}$ prothrombin activation was started with the addition of a $10 \mu l$ aliquot containing factor $\mathrm{Va}$. Final concentrations reached in the reaction mixture were: 50 $\mathrm{mM}$ Tris ( $\mathrm{pH} 7.9$ at room temp), $175 \mathrm{mM} \mathrm{NaCl}, 2 \mathrm{mM} \mathrm{CaCl}_{2}, 5 \mathrm{nM}$ factor Xa, $50 \mu$ M phospholipid vesicles (10 mole\% brain PS/90 mole \% egg-yolk PC), $0.5 \mu \mathrm{M}$ prothrombin, $0.5 \mathrm{mg} / \mathrm{ml}$ ovalbumin and the factor $\mathrm{Va}$ from the aliquot. Prothrombin activation in the assay mixture was determined by measuring the amount of thrombin formed after 1 min using the chromogenic substrate S2238 (Rosing et al., 1980). The amount of thrombin generated in this assay was linearly dependent on factor $\mathrm{Va}$ (up to some $30 \mathrm{pM}$ factor $\mathrm{Va}$ present in the assay mixture) and from a calibration curve made with known amounts of factor $\mathrm{Va}$ the amount of factor $\mathrm{Va}$ present in the reaction mixture could be calculated. 


\section{RESULTS and DISCUSSION}

Isolation of human factor $V$. Factor $\mathrm{V}$ has been referred to in literature as 'Labile Factor'. This lability is caused by the fact that thrombin is a very efficient activator of factor $\mathrm{V}$. When blood is taken from a donor small amounts of tissue factor or contact activation in the receiving container triggers the coagulation reaction. Although this is initially a rather slow process, it is absolute necessary to take appropriate measures to prevent further activation of the coagulation cascade during the isolation procedure otherwise all coagulation factors, including factor $\mathrm{V}$, will become activated. In general, four measures are taken: First, blood is collected in citrate buffer, this slows down the activation of most coagulation proteins since these reactions are calcium dependent and the factors Va and VIIIa show an absolute requirement for calcium. Second, throughout the whole procedure plastic is used to prevent contact activation. Third, a cocktail of protease inhibitors is added to the plasma and kept in the buffers during the whole isolation procedure and, finally, almost the entire procedure is performed at $4{ }^{\circ} \mathrm{C}$ without interruption.

Table 1. Purification of human factor $\mathrm{V}$ from plasma. Human factor $\mathrm{V}$ was purified as described in EXPERIMENTAL. PROCEDURES. Total protein was calculated from volume and $\mathbf{A}_{280}$ values using an $\mathrm{A}_{280}{ }^{1 \%}$ of 10.0. Total unit values were obtained from measured cofactor $\mathrm{Va}$ activities as describedl in EXPERIMENTAL PROCEDURES (using a $k_{\text {cat }}$ of 6000 for factor Va mediated prothrombin activation).

\begin{tabular}{|c|c|c|c|c|c|c|c|}
\hline 1 & $\begin{array}{l}\text { volume } \\
\text { (mi) }\end{array}$ & $A_{280}$ & $\begin{array}{c}\text { protein } \\
\text { (mg) }\end{array}$ & $\begin{array}{c}\text { total } \\
\text { units } \\
\text { mol* } 10^{-9}\end{array}$ & $\begin{array}{c}\text { specific } \\
\text { activity } \\
\text { nmol/mg }\end{array}$ & $\begin{array}{c}\text { recovery } \\
\%\end{array}$ & $\begin{array}{c}\text { purification } \\
\text {-fold }\end{array}$ \\
\hline plasma & 1600 & 56 & 89600 & 20.7 & 0.00023 & - & 1 \\
\hline Ba-Citrate plasma & 1650 & 56 & 92400 & $\cdot 30.7$ & 0.00033 & 100 & 1.4 \\
\hline $7 \%$ PEG supernatant & 1850 & 30 & 55500 & 33.3 & 0.00060 & 108 & 2.6 \\
\hline $\begin{array}{l}13 \% \text { PEG precipitate } \\
\text { (resuspended) }\end{array}$ & 450 & 54.6 & 24600 & 27.1 & 0.0011 & 88 & 4.8 \\
\hline $\begin{array}{l}\text { DEAE resuspended } \\
\left(\mathrm{NH}_{4}\right)_{2} \mathrm{SO}_{4} \\
\text { precipitate }\end{array}$ & 4 & 58 & 232 & 13.1 & 0.056 & 43 & 244 \\
\hline Superdex & 11 & 1.8 & 19.8 & 6.6 & 0.33 & 21 & 1443 \\
\hline MonoS & 20.5 & 0.224 & 4.6 & 4.6 & 1.0 & 15 & 4329 \\
\hline
\end{tabular}


A

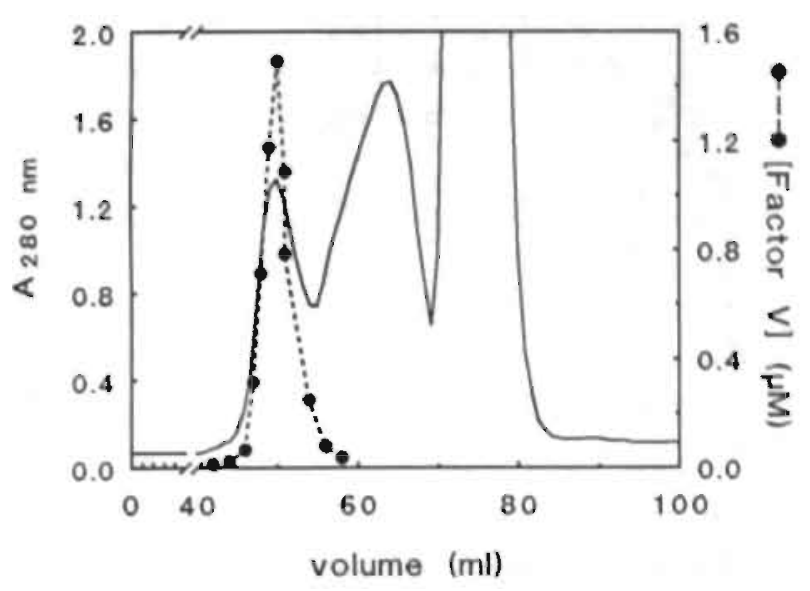

B

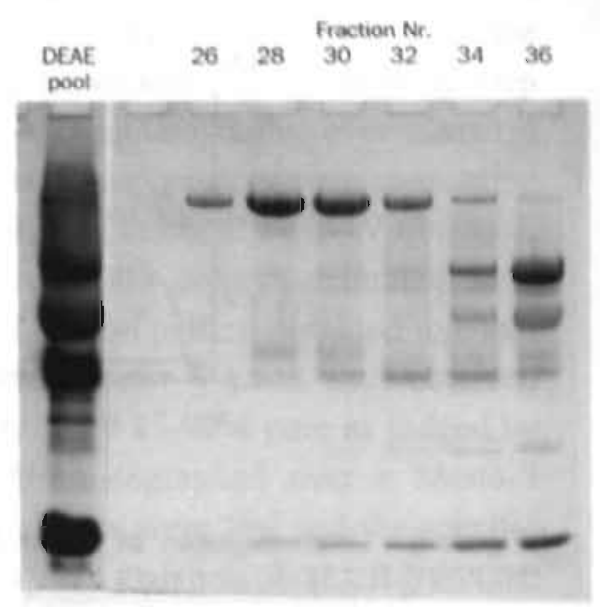

Figure 1. Chromatography of human factor V on FPLC Superdex-200. $4 \mathrm{ml}$ of dissolved ammoniumsulphate precipitate (precipitation was made after DEAE-Sepharose chromatography) was applied to a Superdex-200 column in a buffer containing $10 \mathrm{mM} \mathrm{HEPES}$ (pH 7.5), and $50 \mathrm{mM} \mathrm{NaCI}$ and eluted with the same buffer. Fractions of $1.0 \mathrm{ml}$ were collected at a flow rate of $0.8 \mathrm{ml} / \mathrm{min}$. (A) The absorbance at $280 \mathrm{~nm}$ was continuously recorded (solid line). Samples from the column fractions were incubated for 10 minutes at $37^{\circ} \mathrm{C}$ with thrombin (final concentration $6 \mathrm{nM}$ ) and the factor Va generated ( $\bullet$ ) was assayed as described under EXPERIMENTAL PROCEDURES. (B) $20 \mu \mathrm{l}$ samples were subjected to SDS-PAGE on $5 \%$ gels according to Schägger and von Jagow (1987). Protein was visualized with coommassie brilliant blue R250, The fractions applied to the gel are indicated in the figure. The starting material applied to the column is shown in lane 1. Fractions 28-32 were pooled and further chromatographed on $\mathrm{MonoS}$ as shown in figure 2.

Table 1 shows a typical example of the results obtained during the various steps of the factor $\mathrm{V}$ isolation procedure. The purification is started with a barium citrate adsorption. This removes the vitamin $\mathrm{K}$-dependent proteins from the plasma and reduces the risk of formation of thrombin or other active coagulation factors during subsequent steps. As the vitamin K-dependent proteins are only a small percentage of the total amount of protein present in plasma, this step has no effect on the purification rather than a slight dilution in plasma. Although protein content (by $\mathrm{A}_{280}$ ) and factor $\mathrm{V}$ activity are assayed in dilute samples, the inhibitors present may interfere somewhat with the measurements which may explain the apparent increase 


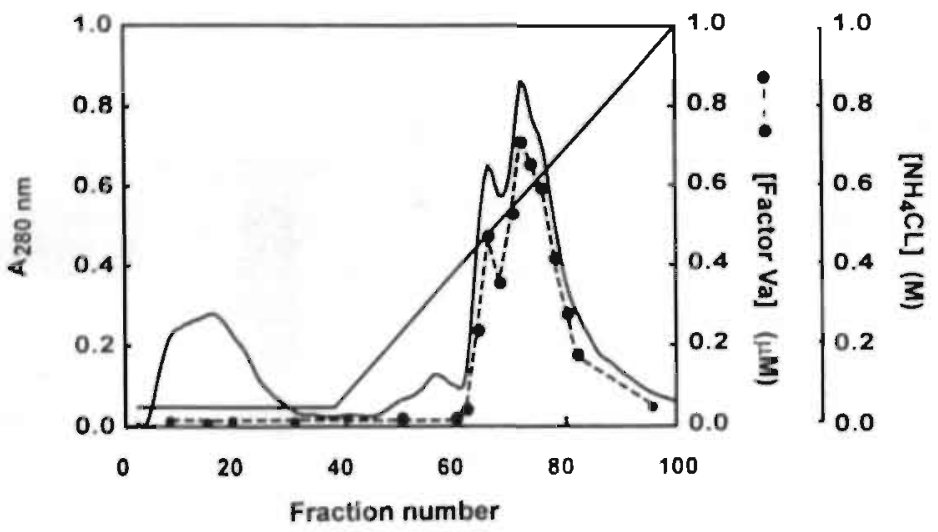

Figure 2. Chromatography of factor $V$ on monoS. $5 \mathrm{ml}$ of purified factor $\mathrm{V}(5 \mathrm{mg})$ in $10 \mathrm{mM}$ HEPES (pH 7.5), $50 \mathrm{mM} \mathrm{NaCl}$ was applied to a MonoS column (HR 5/5). The column was washed with $15 \mathrm{ml}$ of a buffer containing $25 \mathrm{mM}$ HEPES (pH 7.5), $50 \mathrm{mM} \mathrm{NH} 4 \mathrm{Cl}$ and $5 \mathrm{mM} \mathrm{CaCl}$ and subsequently developed with $30 \mathrm{mil}$ of a linear gradient from 50 to $1000 \mathrm{mM} \mathrm{NH}{ }_{4} \mathrm{Cl}$ in $25 \mathrm{mM}$ HEPES (pH 7.5) and $5 \mathrm{mM} \mathrm{CaCl}_{2}$. Samples from the column fractions were incubated for 1 hour at $37{ }^{\circ} \mathrm{C}$ with thrombin (final concentration $25 \mathrm{nM}$ ) and the factor Va generated $(\bullet)$ was assayed as described under EXPERIMENTAL PROCEDURES.

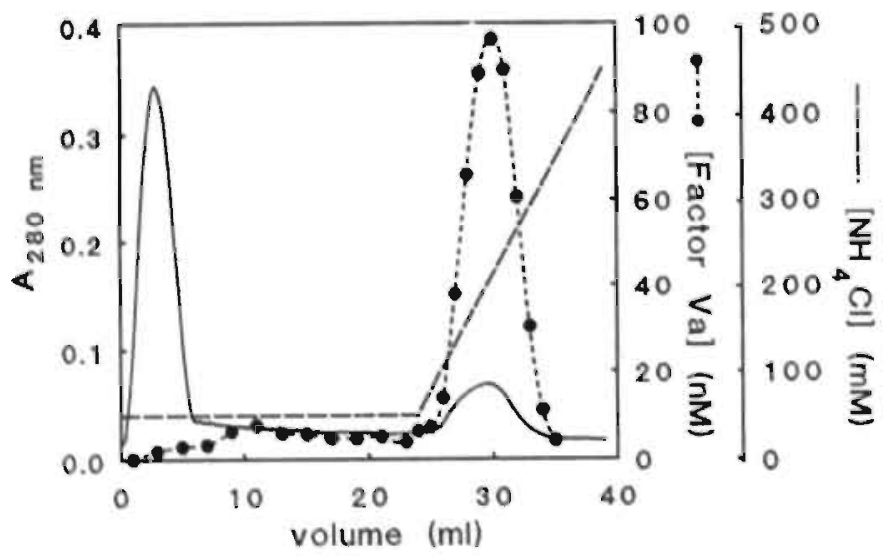

Figure 3. Affinity chromatography of thrombin activated factor $V$ on prothrombin-sepharose gel. A. Factor Va (4 ml $0.4 \mathrm{~A}_{280}$ in $10 \mathrm{mM}$ HEPES (pH 7.5) and $50 \mathrm{mM} \mathrm{NaCl}$ ) was applied to a. prothrombin-sepharose column $(0.5 .5 \mathrm{~cm})$. After sample application, the column was washed with $15 \mathrm{ml}$ column buffer containing $25 \mathrm{mM}$ HEPES pH $7,5,50 \mathrm{mM} \mathrm{NH} 4 \mathrm{Cl}$ and $5 \mathrm{mM} \mathrm{CaCl}$, Elution was accomplished with a $15 \mathrm{ml}$ linear gradient from $50-450 \mathrm{mM} \mathrm{NH}_{4} \mathrm{Cl}$ in $25 \mathrm{mM}$ HEPES (pH 7.5), $5 \mathrm{mM} \mathrm{CaCl} 2.1 \mathrm{ml}$ fractions were collected during the gradient elution. The $\mathbf{A}_{280}$ signal is indicated by a solid line. Samples from the column fractions were assayed for factor Va activity (•) as described under EXPERIMENTAL. PROCEDURES. The $\mathrm{NH}_{4} \mathrm{Cl}$ gradient is indicated by the interrupted line. 
in total protein and activity observed during the first few steps. The results obtained up to and including the DEAE-Sepharose are in reasonable agreement with the results reported for these steps by Dahlbaick and coworkers. The following step reported by these authors involves gel permeation chromatography over classical media such as AcA-34. The use of such columns is, however, very time consuming and in our hands resulted in variable yield and quality of the final factor $\mathrm{V}$ obtained. In order to improve on this, we used a Superdex-200 column mounted in a Pharmacia FPLC system. Figure 1 shows a typical elution pattern obtained together with a SDS slabgel of the various column fractions. Factor $V$ pools thus obtained still contained some contaminants and were usually some $85-90 \%$ pure as judged by SDS-gel electrophoresis. When factor $\mathrm{V}$ was chromatographed over a Mono-S column on a FPLC system (Figure 2) these contaminants were lost and the specific activity increased some three-fold as compared to the material obtained from the Superdex column. This large increase in specific activity as compared to the relatively minor decrease in contaminants observed in SDS-gels (Table 1, $c f$, also Figures $1 \mathrm{~B}$ and 4 ) suggests that the contaminating protein removed had a large extinction coefficient or that part of the protein band identified as factor $\mathrm{V}$ was in fact non-active protein. The purified factor $\mathrm{V}$ was stored at $-80^{\circ} \mathrm{C}$ without additions and was stable for at least several months as judged from its activity and by SDSPAGE. The procedure described here has been repeated several times and each time preparations of comparable high quality were obtained.

Purification of factor Va on a Prothrombin-Sepharose column. Factor Va has been demonstrated to bind to immobilized prothrombin (Guinto and Esmon, 1984). We used bovine prothrombin covalently coupled to $\mathrm{CNBr}$ activated sepharose to separate human factor $\mathrm{Va}$ from its activation peptides. In our preparations the factor $\mathrm{Va}$ activities increased 80 - to 100 - fold after activation by thrombin which is 3 -fold higher than the preparations reported by Kane and Majerus (1981) and Suzuki el al., (1982). During loading and washing of the Prothrombin-sepharose column, small amounts of factor $\mathrm{Va}$ leaked from the column at low salt concentrations. After elution of the column with a linear gradient, approximately $60-70 \%$ of the initiall factor Va activity was eluted from the Prothrombin-Sepharose at $200 \mathrm{mM} \mathrm{NH}_{4} \mathrm{CI}_{\text {. }}$ This resulted in highly purified factor Va. An additional advantage of the use of this column is that small contaminations present in the initial factor $\mathrm{V}$ preparations are also lost after this step. Figure 3 shows a typical chromatogram of a factor Val purification on the Prothrombin-Sepharose column. Polyacrylamide gel analysis of the factor Va eluted from. the Prothrombin-Sepharose column showed that no 
activation peptides eluted in the gradient (not shown). Figure 4 shows an SDS-gel of the final preparations (factor $\mathrm{V}$ and factor $\mathrm{Va}$ ) obtained using the procedures described here. Factor Va lost $10 \%$ of its activity after freezing and thawing. Presence of $5 \mathrm{mg} / \mathrm{ml}$ BSA proved to be essential.

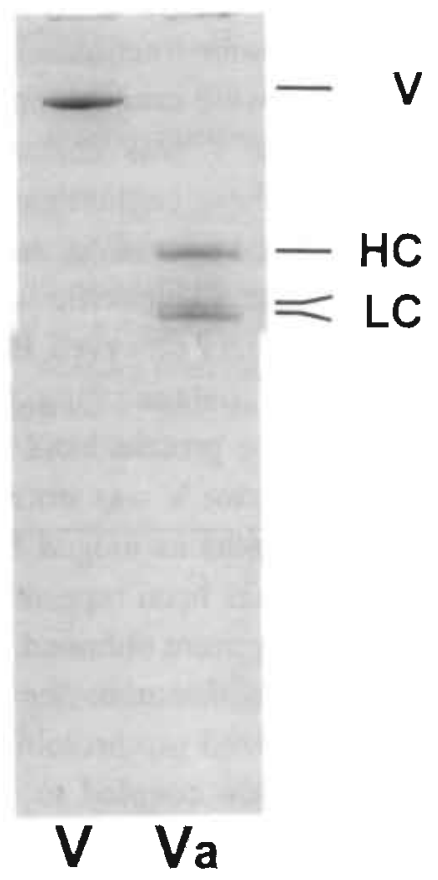

Figure 4. SDS gelelectrophoretic analysis of facor V and factor Va. $20 \mu \mathrm{l}$ of final preparations of factor $\mathrm{V}$ after MonoS and factor $\mathrm{Va}$ after affinity chromatography were subjected to SDS-PAGE on $7.5 \%$ gels according to Schägger and von Jagow (1987). Protein was visualized with coommassie brilliant blue R250. 



\section{Protein $\mathrm{C}$ activation by an activator purified from the venom of Agkistrodon halys halys}

\section{ABSTRACT}

The protein C activator from Agkistrodon halys halys venom has been purified 533-fold by ion-exchange chromatography on QAE-Sephadex A-50, affinity chromatography on aprotinin-Sepharose and Mono-Q fast protein liquid chromatography. The purified enzyme is a single chain protein with an apparent molecular weight of 36,000 that activates protein $\mathrm{C}$ by proteolytic removal of a small fragment from the heavy chain. The protein $\mathrm{C}$ activator exhibited a high amidolytic activity towards the tripeptide substrates D-Pro-Phe-Arg-pNA (S2302) and D-Phe-(pipecolyl)-Arg-pNA (S2238). The activity of the activator was not affected by thiolprotease or metalloprotease inhibitors. The activator was inhibited, however, by benzamidine, Phe-Pro-Arg chloromethyl ketone, $p$-nitrophenyl $p$ guanidinobenzoate and soy bean trypsin inhibitor, which classifies the enzyme as a serine protease. The purified protease was capable of activating both human and bovine protein $C$. Activation of human protein $C$ only occured at an appreciable rate in a calcium-free reaction medium at low ionic strength. $\mathrm{Ca}^{2+}$ ions inhibited the activation of human protein $\mathrm{C}$ with an apparent $K_{\mathrm{i}}$ of $0.8 \mathrm{mM}$. Addition of $\mathrm{NaCl}$ to the reaction medium also strongly inhibited human protein $\mathrm{C}$ activation $(50 \%$ inhibiton at $20 \mathrm{mM} \mathrm{NaCl}$ ). Kinetic analysis of human protein $\mathrm{C}$ activation by the venom activator (in a calcium-free medium) revealed an apparent $K_{\mathrm{m}}$ for protein C of $0.52 \mu \mathrm{M}$ and a $k_{\mathrm{cat}}$ of $0.17 \mathrm{~s}^{-1}$ at $\mathrm{I}=0.05\left(k_{\mathrm{cat}} / K_{\mathrm{m}}=3.3 \times 10^{5} \mathrm{M}^{-1} \mathrm{~s}^{-1}\right)$. At I $=0.15$ rates of human protein $\mathrm{C}$ activation became linear with protein $\mathrm{C}$ indicating a strong increase in $K_{\mathrm{m}}$ with increasing ionic strength. Activation of bovine protein $\mathrm{C}$ was hardly affected by variation of $\mathrm{Ca}^{2+}$ and $\mathrm{NaCl}$ concentrations in the reaction medium. The apparent $K_{\mathrm{i}}$ 's for calcium ion and $\mathrm{NaCl}$ inhibition of bovine protein $\mathrm{C}$ activation were $>10 \mathrm{mM}$ and $220 \mathrm{mM}$, respectively. At $\mathrm{I}=0.1$ and in the absence of $\mathrm{Ca}^{2+}$ ions bovine protein $\mathrm{C}$ was activated with a $K_{\mathrm{m}}$ of $0.056 \mu \mathrm{M}$ and a $k_{\text {cat }}$ of 0.24 $\mathrm{s}^{-1}\left(k_{\mathrm{cat}} / K_{\mathrm{m}}=4.3 \times 10^{6} \mathrm{M}^{-1} \mathrm{~s}^{-1}\right)$. Our data are indicative for a rather large conformational and/or structural difference between human and bovine protein $\mathrm{C}$ at physiological ionic strength. 


\section{INTRODUCTION}

Protein $\mathrm{C}$ is a vitamin $\mathrm{K}$-dependent glycoprotein that circulates in the blood as the zymogen of the serine protease, activated protein C (Stenflo, 1976). Protein C $(\mathrm{MW}=62,000 \mathrm{Da})$ consists of a heavy chain $(\mathrm{MW}=41,000 \mathrm{Da})$ and a light chain $(\mathrm{MW}=21,000 \mathrm{Da})$ linked via a disulfide bridge (Kisiel, 1979). After activation protein $\mathrm{C}$ is converted into activated protein C (APC), which is an efficient inhibitor of blood coagulation whose anticoagulant properties have been attributed to its ability to inactivate factor V (Kisiel et al., 1977; Walker et al., 1979) and factor VIII (Vehar and Davie, 1980; Fulcher et al., 1984; Fay et al., 1982) and to promote fibrinolysis (Comp and Esmon, 1981). In vivo protein $\mathrm{C}$ activation occurs at the endothelial cell surface and is catalyzed by the thrombin-thrombomodulin complex (Esmon and Owen, 1981) which in case of human protein C removes a dodecapeptide from the aminoterminal end of the heavy chain (Kisiel, 1979).

Protein C is also activated by trypsin (Kisiel et al., 1976), the factor X activator from Russell's viper venom (Kisiel et al., 1976) and by proteases from the venoms of the Southem copperhead, Agkistrodon contortrix contortrix (Klein and Walker, 1986; Stocker et al., 1987; Kisiel et al., 1987a; Kisiel et al., 1987b; Orthner et al., 1988; Exner and Vaasjoki, 1988) and the tropical moccasin, Agkistrodon bilineaius (Nakagaki et al., 1990). Finally, an activator from Agkistrodon halys was reported which displayed in vivo antithrombotic properties in a rat model that were attributed to protein C activation (Strukova et al., 1989).

Protein $\mathrm{C}$ activation by non-physiological activators is of special interest since such activators can be used as a tool in studies on the structure-function relationship of protein $C$, in the preparation of APC from protein $C$ and in the development of functional protein $\mathrm{C}$ assays. With respect to the latter application the protein $\mathrm{C}$ activator from Agkistrodon contortrix contortrix received considerable attention (Martinoli and Stocker, 1989). Initially conflicting reports appeared concerning the physical and functional properties of the Agkistrodon contortrix contortrix activator (Kiein and Walker, 1986; Kisiel et al., 1987a; Kisiel et al., 1987b; Orthner et al., 1988; Martinoli and Stocker, 1986). However, the primary structure that became available in 1989 showed the activator to be a serine protease with a MW of $31,000 \mathrm{Da}$ with a high degree of sequence identity to other snake venom (thrombin-like) proteases such as batroxobin, flavoxobin and the factor $\mathrm{V}$ activator from Russell's viper (McMullen et al., 1989). Thus, it is now generally accepted that Agkistrodon contortrix contortrix venom contains a single protein C 
activator which is a serine protease with an apparent molecular weight of 37,000 $40,000 \mathrm{Da}$ as judged by SDS-PAGE and with an isoelectric point in the basic region (Kisiel et al., 1987b; Orthner et al., 1988; McMulien et al., 1989; Meier et al., 1988). The activator readily activates both human and bovine protein $\mathrm{C}$ in a reaction that is strongly inhibited by calcium ions (Kisiel et al., 1987a; Orthner et al., 1988) and (at least in the case of human protein $\mathrm{C}$ ) by $\mathrm{NaCl}$ (Orthner et al., 1988). This phenomenon is of special importance for the use of this activator in a quantitative protein $\mathrm{C}$ assay which because of this sensitivity requires well-controlled reaction conditions with respect to the ionic strength and the free $\mathrm{CaCl}_{2}$ concentration.

During a screening of the pro- and anticoagulant actions of Central Asian snake venoms it was observed that the venom from Agkistrodon halys halys contained considerable anticoagulant activity (Sadykov et al., 1985; Yukelson ef al., 1991). Preliminary experiments in bovine plasma and with bovine protein C indicated that part of the anticoagulant activity of the venom was due to the presence of a protein $\mathrm{C}$ activator. The activity of this venom activator on bovine protein $\mathrm{C}$ was neither affected by $\mathrm{Ca}^{2+}$ ions nor by increasing ionic strength. In this paper we report the purification of this activator which after further characterization appears to differ from the protein $\mathrm{C}$ activator from Agkistrodon contortrix contortrix with respect to its catalytic properties towards bovine protein $\mathrm{C}$. 


\section{EXPERIMENTAL PROCEDURES}

Materials - Crude lyophilized venom from Agkistrodon halys halys was supplied by the Institute of Zoology and Parasitology, Uzbek Academy of Sciences, Tashkent, Uzbekistan and was dissolved at a concentration of $25 \mathrm{mg} / \mathrm{ml}$ in $25 \mathrm{mM}$ Tris/ $\mathrm{HCl}\left(\mathrm{pH} 7.5\right.$ at $\left.4{ }^{\circ} \mathrm{C}\right), 50 \mathrm{mM} \mathrm{NaCl}, 1 \mathrm{mM}$ EDTA. Non-soluble material was removed by centrifugation. The chromogenic substrates D-Phe(pipecolyl)-Arg-pNA (S2238), Glp-Pro-Arg-pNA (S2366), D-Pro-Phe-Arg-pNa (S2302), D-Val-Leu-Lys-pNa (S2251), Ile-Glu-Gly-Arg-pNA (S2222), Ile-Glu(piperidyl)-Gily-Arg-pNA (S2337), N-a-Benzylcarbonyl-D-Arg-Gly-Arg-pNA (S2765), D-Ile-Pro-Arg-pNA (S2288) were obtained from Chromogenix (Mölndal, Sweden). p-Nitrophenyl-p-guanidinobenzoate (p-NPGB) was from Nutritional Biochemicals, USA. N-Tosyl-Gly-Pro-Arg-NH-Np (Chromozym-TH) was from Boehringer, Mannheim, Germany. Agarose (Indubiose A37-HAA) was from IBF Biotechnics, France. Ovalbumin, bovine serum albumin, o-phenantrolin, 2iodoacetamide, n-ethylmaleimide, p-amidino-PMSF, benzamidin $/ \mathrm{HCl}$, soybean trypsin inhibitor and aprotinin were from Sigma Chemicals (St. Louis, MO, USA). D-Pro-Phe-Arg- $\mathrm{CH}_{2} \mathrm{Cl}$ (PPACK) was from Calbiochem-Behring Corp, USA. Materials used for the purification of proteins were purchased from Pharmacia Fine Chemicals, Uppsala, Sweden. Protac, a partially purified protein C activatoi preparation from Agkistrodon contortrix contortrix, was obtained from Pentapharm, Basel, Switzerland. Bovine protein C was a kind gift of Dr. R. Wagenvoord (Department of Biochemistry, CARIM, Maastricht).

Proteins - Human protein $\mathrm{C}$ was isolated from citrated humañ plasma as follows. A barium precipitate was prepared by adding $8 \mathrm{ml} 1 \mathrm{M} \mathrm{BaCl}_{2} / 100 \mathrm{ml}$ plasma. The precipitate was collected by centrifugation, washed with $1 / 3$ volume of $0.15 \mathrm{M} \mathrm{BaCl}_{2}, 10 \mathrm{mM}$ benzamidin/ $\mathrm{HCl}$ and resuspended in $1 / 3$ yol $10 \%$ saturated $\mathrm{NH}_{4} \mathrm{SO}_{4}$. The precipitate was removed by centrifugation and the supernatant was subsequently brought to $40 \% \mathrm{NH}_{4} \mathrm{SO}_{4}$ and then to $70 \% \mathrm{NH}_{4} \mathrm{SO}_{4}$. The $40-70 \%$ $\mathrm{NH}_{4} \mathrm{SO}_{4}$ precipitate was dissolved in $50 \mathrm{mM}$ Tris- $\mathrm{HCl}$ (pH 8.0), $100 \mathrm{mM} \mathrm{NaCl}, 10$ $\mathrm{mM}$ benzamidin/ $\mathrm{HCl}$ and dialysed extensively against the same buffer before it was passed though a column of C-9 Sepharose ( $1.3 \mathrm{mg}$ anti-protein C monoclonal C-9 coupled/ $\mathrm{ml}$ sepharose). The column was washed with the same buffer containing $0.3 \mathrm{M} \mathrm{NaCl}$ till the effluent was essentially protein free. Protein $\mathrm{C}$ was then eluted with $0.1 \mathrm{M}$ glycine $(\mathrm{pH} \mathrm{2.45)}$ and collected in Tris $(\mathrm{pH} \mathrm{8.0)}$ followed by dialysis against a suitable buffer. SDS-PAGE analysis of non-reduced and reduced samples 
showed this protein $\mathrm{C}$ to be more than $95 \%$ pure. Molar concentrations were calculated by measuring the protein $\mathrm{C}$ antigen concentration by specific ELISA and using a MW of $56,000 \mathrm{Da}$.

The protein C activator present in crude Agkistrodon halys halys venom was purified as follows. $722 \mathrm{mg}$ crude venom dissolved in $35 \mathrm{ml} 25 \mathrm{mM}$ Tris/ $\mathrm{HCl}$ (pH 7.5 at $4{ }^{\circ} \mathrm{C}$ ), $50 \mathrm{mM} \mathrm{NaCl}, 1 \mathrm{mM}$ EDTA was applied to a QAE-Sephadex column $(2.5 \times 21 \mathrm{~cm})$ equilibrated in the same buffer and the column was washed with three column volumes $25 \mathrm{mM}$ Tris $/ \mathrm{HCl}\left(\mathrm{pH} 7.5\right.$ at $\left.4{ }^{\circ} \mathrm{C}\right), 100 \mathrm{mM} \mathrm{NaCl}, 1 \mathrm{mM}$ EDTA. Venom proteins that adhered to the column were eluted with a linear salt gradient of $2 \times 250 \mathrm{ml}$ from 100 to $500 \mathrm{mM} \mathrm{NaCl}$. Column fractions were tested for the presence of a protein $\mathrm{C}$ activator as described below. The activator adhered to the column and eluted in the gradient at about $200 \mathrm{mM} \mathrm{NaCl}$. Fractions containing the protein $\mathrm{C}$ activator were pooled and dialysed against $20 \mathrm{mM}$ Hepes (pH 7.5) and subsequently applied to an aprotinin-Sepharose column $(35 \mathrm{mg}$ aprotinin coupled to $10 \mathrm{ml} \mathrm{CNBr}$-Sepharose according to the manufacturers instructions). The protein $\mathrm{C}$ activator bound to the aprotinin-Sepharose column which was then washed with five column volumes $20 \mathrm{mM}$ Hepes ( $\mathrm{pH} 7.5$ ), $50 \mathrm{mM} \mathrm{NaCl}$ and developed with a linear salt gradient $(2 \times 40 \mathrm{ml})$ of $50-300 \mathrm{mM} \mathrm{NaCl}$ in the same buffer. The activator eluted at about $125 \mathrm{mM} \mathrm{NaCl}$. The fractions containing protein $\mathrm{C}$ activator were pooled, dialysed against $25 \mathrm{mM}$ Tris ( $\mathrm{pH} 7.5$ at room temp), $50 \mathrm{mM} \mathrm{NaCl}, 1 \mathrm{mM}$ EDTA and subjected to ion-exchange chromatography on a Mono-Q column connected to an FPLC-system of Pharmacia. The activator adhered to the column and was eluted with a linear salt gradient of $50-300 \mathrm{mM} \mathrm{NaCl}$. To remove the final contaminants the fractions containing activator were pooled, dialysed against 25 $\mathrm{mM}$ Tris ( $\mathrm{pH} 7.5$ at room temp), $50 \mathrm{mM} \mathrm{NaCl}, 1 \mathrm{mM}$ EDTA and rechromatographed on Mono-Q. The column was washed with 10 column volumes start buffer and developed with a linear gradient of 50 to $150 \mathrm{mM} \mathrm{NaCl}(5 \mathrm{ml}$ total volume). Elution with $150 \mathrm{mM} \mathrm{NaCl}$ containing buffer was continued during which the activator eluted as a single peak.

Protein C activation - During the purification of the Agkistrodon halys halys activator protein $C$ activation was routinely determined as follows. $40 \mu \mathrm{l}$ column fraction, appropriately diluted in $20 \mathrm{mM}$ Hepes ( $\mathrm{pH} 7.5$ ), $1 \mathrm{mM}$ EDTA, $0.5 \mathrm{mg} / \mathrm{ml}$ ovalbumin, was preincubated at $37^{\circ} \mathrm{C}$ for 5 minutes and protein $\mathrm{C}$ activation was started by adding $10 \mu \mathrm{l}$ of $1 \mu \mathrm{M}$ bovine protein $\mathrm{C}$ (prewarmed) in the same buffer. After an additional five minutes a $25 \mu \mathrm{l}$ aliquot of the activation mixture was transferred to a cuvette with $475 \mu \mathrm{l}$ of a buffer containing $50 \mathrm{mM}$ Tris (pH 7.9 at 
room temp), $175 \mathrm{mM} \mathrm{NaCl}, 20 \mathrm{mM}$ EDTA, $0.5 \mathrm{mg} / \mathrm{ml}$ ovalbumin and $192 \mu \mathrm{M}$

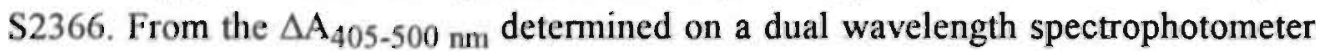
the amount of activated protein $\mathrm{C}$ was calculated using the kinetic parameters for \$2366 conversion by bovine APC given by the manufacturer.

Initial rates of protein $C$ activation by the purified activator were determined in a total reaction volume of $250 \mu \mathrm{l}$ as follows. Varying amounts of protein $\mathrm{C}$ were preincubated for 5 minutes at $37{ }^{\circ} \mathrm{C}$ in a reaction buffer (composition given in the legends to the figures) and protein $\mathrm{C}$ activation was started by the addition of $10 \mu \mathrm{l}$ of purified activator in the same buffer. Aliquots of $25 \mu \mathrm{l}$ were removed at 1,3 and 5 minutes from the reaction mixture and assayed for activated protein C with S2366 as described above. Quantitation of human APC was based on the kinetic parameters of S2366 conversion by human APC reported by Sala et al. (1984). Rates of protein $\mathrm{C}$ activation were linear with time and proportional to the amount of activator added and expressed in nM APC formed per minute. Further experimental details are given in the legends to the figures.

Gel elecirophoresis - Electrophoresis of proteins was carried out as described by Laemmli (1970) on $10 \%$ polyacrylamide gels ( $6 \%$ stacking gel) in the presence of SDS. After electrophoresis the gels were stained for protein with Coomassie Brilliant blue R250. Zymographic detection of the protein C activator was carried out using the amidoblot procedure described earlier Tans et al., 1989). To this end the activator was transblotted onto nitrocellulose and SDS was removed by soaking the nitrocellulose sheet for 3 hrs at room temperature in $25 \mathrm{mM}$ Tris (pH 7.9), 90 $\mathrm{mM} \mathrm{NaCl}$ containing $2.5 \%$ Triton $\mathrm{X}-100$ followed by four washes ( 7.5 minutes) in $25 \mathrm{mM}$ Tris ( $\mathrm{pH} \mathrm{7.9)}$. The nitrocellulose sheet was subsequently placed on an agarose gel of $1.25 \%$ agarose in $25 \mathrm{mM}$ Tris ( $\mathrm{pH}$ 7.9), $1 \mathrm{mM}$ EDTA, $480 \mu \mathrm{M}$ S2366 and $0.5 \mu \mathrm{M}$ bovine protein $\mathrm{C}$. If there is protein $\mathrm{C}$ activator present on the nitrocellulose sheet APC is formed which liberates p-nitroaniline from the chromogenic substrate in the agarose and generates a yellow band on the nitrocellulose sheet. This band can be photographed by transillumination with UV-A light to achieve optimal contrast. 


\section{RESULTS}

Purification of the protein C activator from Agkistrodon halys halys venom The protein $\mathrm{C}$ activator was purified from the crude venom by a combination of standard chromatographic techniques involving ion-exchange chromatography on QAE-Sephadex, affinity chromatography on aprotinin-Sepharose and repeated ionexchange chromatography on a Mono-Q column connected to a Pharmacia FPLC system. Table 1 summarizes the purification procedure (details are given under Experimental Procedures). which resulted in 533 -fold purification at a $13 \%$ overall yield.

Table 1. Purification of a protein $\mathrm{C}$ activator from the venom of Agkistrodon halys halys. Protein concentrations were calculated from the absorbance at $280 \mathrm{~nm}$ assuming $A_{280} 1 \%=10$. Further details are described under EXPERIMENTAL. PROCEDURES and in the text.

\begin{tabular}{|c|c|c|c|c|}
\hline & $\begin{array}{l}\text { Proteina } \\
\text { (mg) }\end{array}$ & $\begin{array}{c}\text { Specific } \\
\text { activity } \\
\text { (nmole } \mathrm{APC} / \mathrm{min} / \mathrm{mg} \text { ) }\end{array}$ & $\begin{array}{l}\text { Yield } \\
(\%)\end{array}$ & $\begin{array}{l}\text { Purifi- } \\
\text { cation } \\
\text { (-fold) }\end{array}$ \\
\hline crude venom & 722. & 0,6 & 100 & 1 \\
\hline QAE Sephadex & 41 & 3.5 & 33 & 5.8 \\
\hline \multicolumn{2}{|c|}{ Aprotinin Sepharose 11.4} & 12.0 & 31 & 20 \\
\hline MonoQ 1 & 0.9 & 98 & 20 & 163 \\
\hline MonoQ 2 & 0.17 & 320 & 13 & 533 \\
\hline
\end{tabular}

Figure 1A shows a non-reduced SDS-polyacrylamide gel of the crude venom (lane 1), the purified activator (lane 2) and protein standards (lane 3). The purified activator appeared homogeneous and pure $(>95 \%)$, and migrated as a single band with an estimated MW of $36,000 \mathrm{Da}$. SDS-PAGE of reduced samples also showed a single band at $36,000 \mathrm{Da}$ indicating that the activator is a single chain protein (not shown).

The protein $\mathrm{C}$ activator on the gel was also identified by a modification of the amidoblot procedure described by Tans et al. (1989). The purified protein C activator was subjected to SDS-PAGE and transblotted onto nitrocellulose. The nitrocellulose sheet was washed and subsequently placed on a layer of agarose 
containing protein $\mathrm{C}$ and the protein C-specific chromogenic substrate S2366 (Figure 1B). The appearance of a yellow band (i.e. paranitroaniline production from S2366 by APC generated in the agarose) at the migrating distance of the protein band (lane 2 Fig. 1A) indicates that the protein visible on the Coomassie blue stained gel and the protein $\mathrm{C}$ activator are one and the same protein. In this respect it should be mentioned that the appearance of the yellow band was not due to direct conversion of S2366 by the purified venom protein since omission of protein $\mathrm{C}$ from the agarose resulted in a complete loss of p-nitroaniline formation (data not shown).

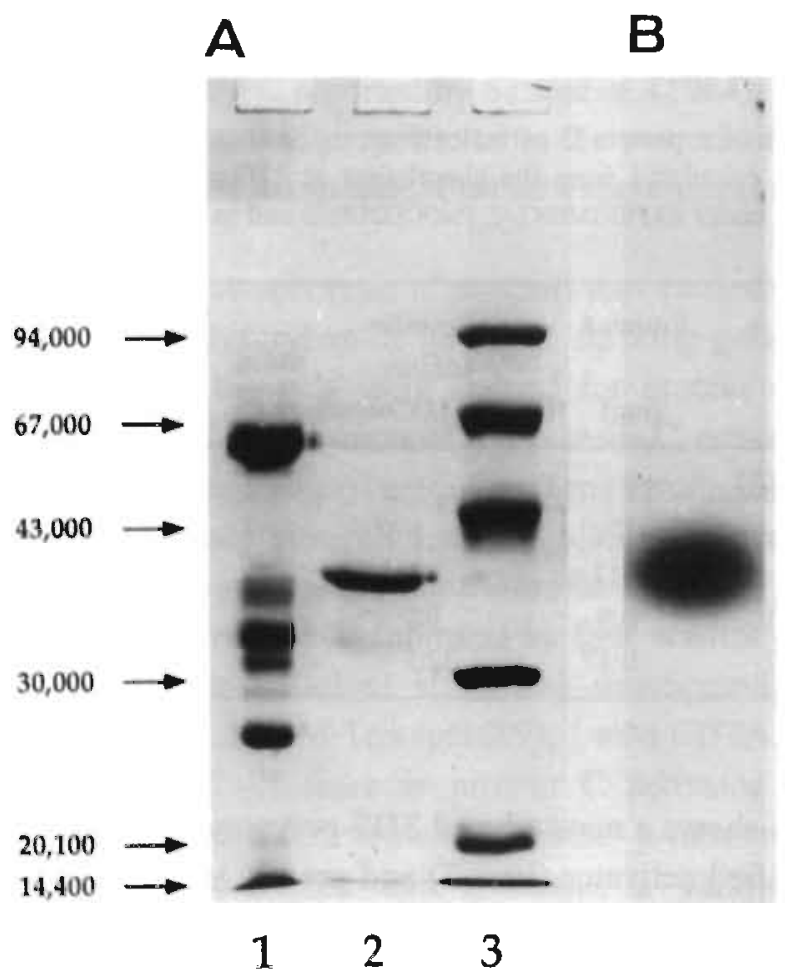

Figure 1. SDS-PAGE analysis of the protein C activator from the venom of Agkistrodon halys halys. Crude Agkistrodon halys halys venom and purified, activator were subjected to SDS-PAGE on $10 \%$ slabgels (6\% stacking gel) according to Laemmli (1970) under non-reducing conditions. (A) Gel stained with Coomassie Brilliant Blue R250. Lane I, $13 \mu \mathrm{g}$ crude venom; Lane 2, $4 \mu \mathrm{g}$ purified activator; Lane 3, molecular weight standards. (B) After electrophoresis a separate part of the gel containing a lane with $4 \mu \mathrm{g}$ purified activator was subjected to electrophoretic transfer of the protein onto nitrocellulose and visualization of the protein $\mathbf{C}$ activator with protein C and S2366 as described in EXPERIMENTAL. PROCEDURES. 
The product of protein $C$ activation by the protein $C$ activator - Human protein $\mathrm{C}$ is a protein with a molecular weight of 62,000 that consists of aheavy chain $(41,000 \mathrm{Da})$ linked via a disulfide bridge to a light chain $(21,000 \mathrm{Da})$. Activation of human protein $\mathrm{C}$ results from a specific cleavage in the heavy chain of the molecule (Kisiel, 1979; Kisiel et al., 1987b; Nakagaki et al., 1990). In the case of protein $\mathrm{C}$ activation by its physiological activator, thrombin this cleavage has been identified to result in the removal of a dodecapeptide of $1,400 \mathrm{Da}$ from the aminoterminus of the heavy chain (Kisiel, 1979).

Figure 2 shows that the protein $\mathrm{C}$ activator purified from Agkistrodon halys halys venom very likely activates human protein $\mathrm{C}$ via the same pathway. Activation of protein $\mathrm{C}$ by our activator was accompanied by the cleavage of a small polypeptide from the heavy chain of protein $\mathrm{C}$ as indicated by the small increase in

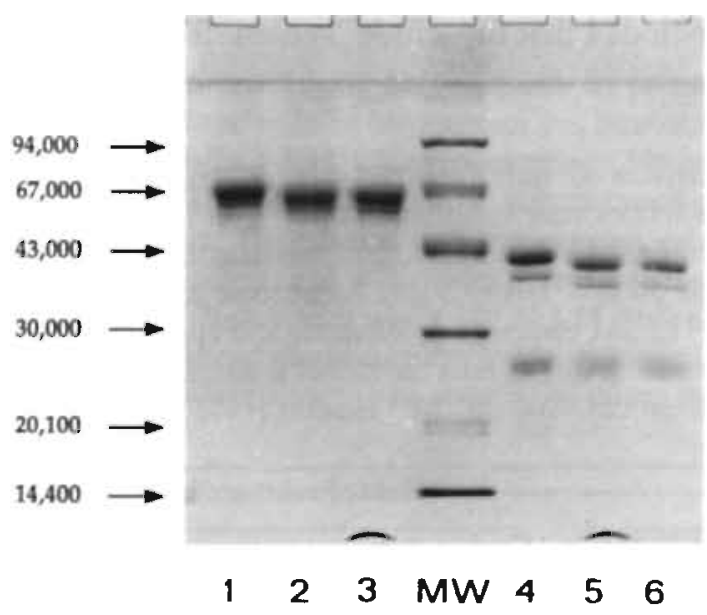

Figure 2. SDS-PAGE of protein C activated by the activators from the venoms of Agkisirgdon halys halys and Agkistrodon contortrix contortrix. Human protein $C(16 \mu \mathrm{g})$ was activated in $100 \mu \mathrm{l}$ of at reaction buffer containing $50 \mathrm{mM}$ Tris/ $/ \mathrm{HCl}$ (pH 7.9 at room temp), $0.5 \mathrm{mM}$ EDTA and $0.08 \mu \mathrm{g}$ of the purified activator from Agkistrodon halys halys or $0.12 \mu \mathrm{g}$ Protac (partially purified activator from Agkistrodon contortrix contortrix). After complete reaction $20 \mu \mathrm{l}$ aliquots were taken and subjected to SDS-PAGE both under non-reduced (lanes 1-3) and under reduced (lanes 4-6) conditions. A lane with molecular weight standards (identified as MW) was included on the gel. After electrophoresis the gel was stained with Coomassie Brilliant Blue R250. Lanes 1 and 4, protein C, Lanes 2 and 5, protein C activated with activator purified from the venom of Agkistrodon halys halys; Lane 3 and 6, protein C activated with Protac, the activator from Agkistrodon contoririx contortrix. 
electrophoretic mobility of the heavy chain of protein $C$ after complete activation. For comparison we have also electrophoresed the product of protein $\mathrm{C}$ activation by the activator from Agkistrodon contoririx contoririx, which appeared to be indistinguishable from the APC generated by the activator from Agkistrodon halys halys. It is, therefore, highly probable that activation of protein $\mathrm{C}$ by the activators from both Agkistrodon species is due to removal of the same dodecapeptide that is also removed by thrombin (Kisiel, 1979).

Chromogenic substrate conversion by the protein $C$ activator - The purified protein $\mathrm{C}$ activator from the venom of Agkistrodon halys halys possesses amidolytic activity towards a number of commercially available synthetic peptide substrates (Table 2). High activities were observed on the kallikrein substrate S2302 and on the thrombin substrate S2238, whereas other substrates tested were converted at considerably lower rates. In Table 2 we have also included the rates of substrate conversion by the crude venom. From the fact that there was a considerable difference between the substrate specificities of the purified activator and the crude venom it can be concluded that the crude venom from Agkistrodon halys halys

Table 2. Amidolytic activities of crude Agkistrodon halys halys venom and of the purified protein $\mathrm{C}$ activator. Amidolytic activities were determined at $37^{\circ} \mathrm{C}$ in $1 \mathrm{ml}$ cuvettes $(1 \mathrm{~cm}$ pathlength) on an Aminco DW2-C spectrofotometer set in the dual wavelength mode at 405 minus $500 \mathrm{~nm}$. Final reaction conditions were: $50 \mathrm{mM}$ Tris/ $\mathrm{HCl}$ ( $\mathrm{pH} 7.9$ at room temp), $175 \mathrm{mM} \mathrm{NaCl}, 20 \mathrm{mM}$ EDTA, $0.5 \mathrm{mg} / \mathrm{ml}$ ovalbumin, $192 \mu \mathrm{M}$ chromogenic substrate and appropriate amounts of crude venom or purified activator. From the $\Delta \mathrm{A}_{405-500} / \mathrm{min}$ the rate of $\mathrm{p}$-nitroaniline formation was calculated using a molar extinction coefficient of $9900 \mathrm{~cm}^{-1} \mathrm{M}^{-1}$ Hemker (1983).

\begin{tabular}{lcc}
\hline & \multicolumn{2}{c}{ Rate of substrate hydrolysis } \\
\cline { 2 - 3 } Substrate & $\begin{array}{c}\text { Crude venom } \\
(\mu M p N A / \min / m g)\end{array}$ & $\begin{array}{c}\text { Purified activator } \\
(\mu M p N A / m i n / m g)\end{array}$ \\
\hline S2238 & 0.371 & 0.703 \\
Chromozym TH & 0.346 & 0.062 \\
S2222 & 0.036 & 0.029 \\
S2337 & 0.051 & 0.009 \\
S2765 & 0.039 & 0.011 \\
S2366 & 0.129 & 0.027 \\
S2302 & 4.024 & 1.290 \\
S2288 & 0.271 & 0.048 \\
S2251 & 0.286 & 0.043 \\
\hline
\end{tabular}


contains other enzymes with amidolytic activity. Since the crude venom contains less than $0.2 \%$ protein $\mathrm{C}$ activator (as can be concluded from the 533 -fold purification of the activator, Table 1) it can be calculated that the protein $\mathrm{C}$ activator has a negligible contribution to the amidolytic activity of the crude venom.

The effect of protease inhibitors on the activity of the protein $C$ activator Table 3 summarizes the effects of inhibitors of different classes of proteolytic enzymes on the activity of the protein $\mathrm{C}$ activator from Agkistrodon halys halys. Inhibitors of metallo- and thiol proteases did not affect the amidolytic activity of the protein $\mathrm{C}$ activator as determined with $\mathbf{S} 2302$. Considerable inhibition was observed when the protein $C$ activator was incubated with the serineprotease inhibitors benzamidin, soybean trypsin inhibitor, PPACK and p-NPGB. The virtually complete inhibition by pNPGB and PPACK suggests that the protein $\mathrm{C}$ activator from Agkistrodon halys halys is a serine protease in which both histidine- and serine residues are involved in the catalytic mechanism.

Table 3. Inhibition of the purified Agkistrodon halys halys activator by protease inhibitors. $0.77 \mu \mathrm{g}$ Protein $\mathrm{C}$ activator purified from Agkistrodon halys halys venom was incubated for $1 \mathrm{hr}$ at $37{ }^{\circ} \mathrm{C}$ in $450 \mu$ buffer containing $50 \mathrm{mM}$ Tris $/ \mathrm{HCl}$ (pH 7.9 at room temp), $175 \mathrm{mM} \mathrm{NaCl}, 0.5 \mathrm{mg} / \mathrm{ml}$ ovalbumin and inhibitor as indicated. The residual amidolytic activity was determined after $1 \mathrm{hr}$ by adding $50 \mu \mathrm{ll} 3.84 \mathrm{mM}$ S2302 in water. The reaction with chromogenic substrate was allowed to proceed (usually between 5 and 25 minutes) until sufficient p-nitroanilide was formed for accurate measurement of the absorbance at 405-500nm after which $300 \mu / 1 \mathrm{M}$ citric acid was added to stop p-nitroaniline formation. From the measured absorbance the amidolytic activity was calculated as $\Delta$ $\mathrm{A}_{405-500} \mathrm{~nm} / \mathrm{min}$. The percentage remaining activity was obtained by taking the activity measured in the absence of inhibitors as $100 \%$.

\begin{tabular}{lcr}
\hline Inhibitor & & $\%$ activity \\
\hline none & & 100 \\
o-phenantrolin & $(4 \mathrm{mM})$ & 94 \\
EDTA & $(10 \mathrm{mM})$ & 107 \\
2-iodoacetamide & $(1 \mathrm{mM})$ & 99 \\
n-ethylmaleimide & $(1 \mathrm{mM})$ & 97 \\
p-amidino PMSF & $(100 \mu \mathrm{M})$ & 98 \\
antithrombin III & $(60 \mathrm{nM})$ & 117 \\
benzamidin & $(10 \mathrm{mM})$ & 48 \\
soybean trypsin inhibitor & $(10 \mathrm{mg} / \mathrm{ml})$ & 66 \\
p-NPGB & $(300 \mu \mathrm{M})$ & 6 \\
PPACK & $(50 \mu \mathrm{M})$ & 4 \\
\hline
\end{tabular}




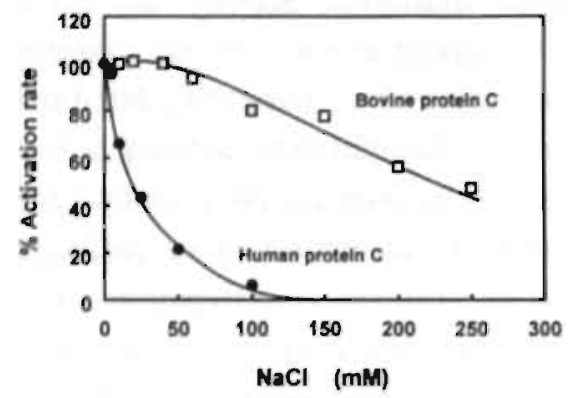

Figure 3. Effect of $\mathrm{NaCl}$ on the rate of protein $\mathrm{C}$ activation by the purified activator from Agkisirodon halys halys venom. Protein $\mathrm{C}$ was preincubated in $240 \mu \mathrm{l}$ reaction buffer for 5 minutes at $37^{\circ} \mathrm{C}$ after which reaction was started with the addition of $10 \mu \mathrm{l}$ buffer containing purified Agkistrodon halys halys activator. Final concen-trations of reactants were: $50 \mathrm{mM}$ Tris/ $\mathrm{HCl}(\mathrm{pH} 7.9$ at room temp), $\mathrm{NaCl}$ as indicated in the figure, $5 \mathrm{mM}$ EDTA, $0.5 \mathrm{mg} / \mathrm{ml}$ ovalbumin, $130 \mathrm{nM}$ human protein $\mathrm{C}$ and $25 \mathrm{ng}$ purified activator (๑) or $150 \mathrm{nM}$ bovine protein $\mathrm{C}$ and $5 \mathrm{ng}$ activator $(\square)$. After 1, 3 and 5 minutes $25 \mu \mathrm{l}$ aliquots were removed from the reaction mixture and assayed for activated protein $\mathrm{C}$ using the chromogenic substrate $\mathbf{S} 2366$ as described under EXPERIMENTAL PROCEDURES. From the amounis of activated protein $\mathrm{C}$ thus determined the initial rate of protein $\mathrm{C}$ activation was calculated. The rate of protein $\mathrm{C}$ activation determined in the absence of $\mathrm{NaCl}$ was taken as $100 \%$ ( $5.9 \mathrm{nM}$ human APC formed per minute and $5.4 \mathrm{nM}$ bovine APC formed per minute).

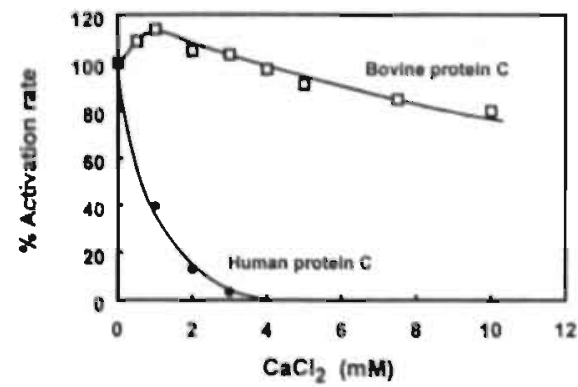

Figure 4. The effect of $\mathrm{CaCl}_{2}$ on the rate of protein $\mathrm{C}$ activation by the activator purified from the venom of Agkistrodon halys halys. Protein C was preincubated in $240 \mu \mathrm{I}$ reaction buffer for 5 minutes at $37{ }^{\circ} \mathrm{C}$ after which reaction was started with the addition of $10 \mu \mathrm{l}$ buffer containing purified Agkistrodon halys halys activator. Final concentrations of reactants were: $50 \mathrm{mM}$ Tris/HCl (pH 7.9 at room temp), $10 \mathrm{mM} \mathrm{NaCl}, 0.5 \mathrm{mM}$ EDTA, $0.5 \mathrm{mg} / \mathrm{ml}$ ovalbumin, $130 \mathrm{nM}$ human protein $C$ with $25 \mathrm{ng}$ activator $(\omega)$ or $150 \mathrm{nM}$ bovine protein $\mathrm{C}$ with $4 \mathrm{ng}$ activator ( $\square$ ) and amounts of $\mathrm{CaCl}_{2}$ in excess over EDTA to obtain the concentrations indicated in the figure. After 1,3 and 5 minutes $25 \mu \mathrm{l}$ aliquots were removed from the reaction mixture and assayed for activated protein $\mathrm{C}$ using the chromogenic substrate S2366 as described under Material and Methods. From the amounts of activated protein $\mathbf{C}$ present the initial (steady-state) rate of protein $\mathrm{C}$ activation was calculated and expressed as percentage of the rate determined in the absence of added $\mathrm{CaCl}_{2}(5.7 \mathrm{nM}$ human $\mathrm{APC}$ formed per minute and $4.2 \mathrm{nM}$ bovine A.PC formed per minute). 
Effect of $\mathrm{CaCl}_{2}$ and $\mathrm{NaCl}$ on the activation of protein $\mathrm{C}$ - During our studies it became clear that the activator isolated from the venom of Agkistrodon halys halys activated both bovine- and human protein $\mathrm{C}$. In this respect it resembles the protein C activator from the venom of Agkistrodon contortrix contoririx. Our protein C activator differs, however, in one important aspect from the latter activator. Activation of both bovine- and human protein $\mathrm{C}$ by the activator from Agkistrodon contortrix contortrix is strongly inhibited by $\mathrm{Ca}^{2+}$ ions (Kisiel et al., 1987; Orthner et al., 1988) and (at least for human protein C) by $\mathrm{NaCl}$ (Orthner et al., 1988). When we tested protein C activation with Protac (the activator form Agkistrodon contortrix contortrix venom) under our experimental conditions, both bovine and human protein $\mathrm{C}$ activation by Protac were strongly inhibited by $\mathrm{CaCl}_{2}\left(K_{\mathrm{i}}\right.$ app $<$ $\mathrm{ImM})$ and by $\mathrm{NaCl}\left(K_{\mathrm{i} \text { app }} \approx 50 \mathrm{mM}\right)$ (data not shown). However, $\mathrm{Ca}^{2+}$ ions and increasing ionic strength had different effects on the activation of bovine and human protein $\mathrm{C}$ by the Agkistrodon halys halys protein $\mathrm{C}$ activator. Figure 3 shows that activation of human protein $\mathrm{C}$ by the activator from Agkistrodon halys halys was strongly inhibited at increasing $\mathrm{NaCl}$ concentrations $\left(K_{\mathrm{i} \text { app }}=20 \mathrm{mM}\right)$ whereas the activation of bovine protein $\mathrm{C}$ was inhibited at much higher $\mathrm{NaCl}$ concentrations $\left(K_{\mathrm{i}}\right.$ app $=220 \mathrm{mM}$ ). A similar difference between bovine and human protein $C$ activation was also observed when the effect of $\mathrm{Ca}^{2+}$ ions was studied (Figure 4). Activation of human protein $\mathrm{C}$ was already inhibited at low $\mathrm{Ca}^{2+}$ concentrations $\left(K_{\mathrm{i}}\right.$ app $=0.8 \mathrm{mM}$ ), whereas bovine protein $\mathrm{C}$ activation was even slightly stimulated at this calcium concentration. At much higher $\mathrm{Ca}^{2+}$ concentrations there was some inhibition of bovine protein $\mathrm{C}$ activation by the activator from Agkistrodon halys halys. The $K_{\mathbf{i} \text { app }}$ for inhibition by $\mathrm{Ca}^{2+}$ ions was, however, much higher than 10 $\mathrm{mM}$.

Kinetic parameters of protein $C$ activation by the protein $C$ activator - To assess the efficiency by which the purified Agkistrodon halys halys enzyme activated human protein $\mathrm{C}$ we determined the kinetic parameters of protein $\mathrm{C}$ activation by measuring initial rates of activation at varying protein $\mathrm{C}$ concentrations. The reaction appeared to be saturable with respect to protein $\mathrm{C}$ (Figure 5A) and obeyed Michaelis-Menten kinetics as evidenced by the straight Lineweaver-Burk plot (Figure 5B). The latter plot yields a $V_{\max }$ of $14.2 \mathrm{nM}$ protein $\mathrm{C}$ activated per minute and $K_{\mathrm{m}}$ for human protein $\mathrm{C}$ of $0.52 \mu \mathrm{M}$. From the concentration of activator present in this experiment $(0.051 \mu \mathrm{g} / \mathrm{ml})$ and the molecular weight of the activator $(36,000)$ it can be calculated that the $k_{\text {cat }}$ is $0.17 \mathrm{~s}^{-}$ 1 and $k_{\mathrm{cat}} / K_{\mathrm{m}}=3.3 \times 10^{5} \mathrm{M}^{-1} \mathrm{~s}^{-1}$. These kinetic parameters were determined in a 

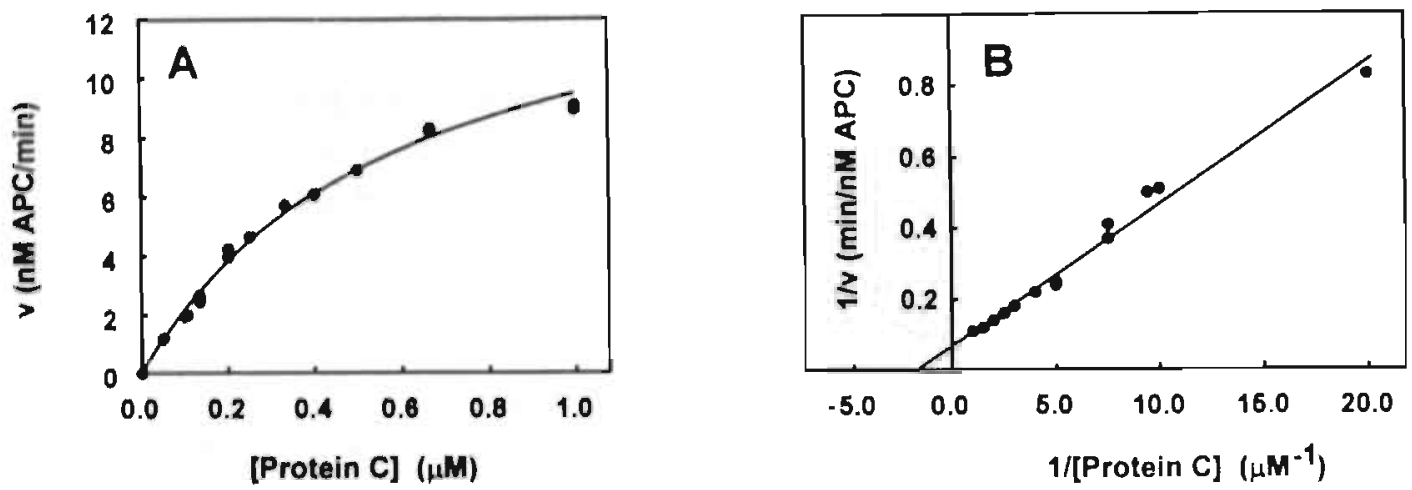

Figure 5. Kinetic analysis of human protein $\mathrm{C}$ activation by the activator purified from the venom of Agkistrodon halys halys. Varying amounts of human protein $\mathrm{C}$ were incubated for 5 minutes at $37^{\circ}$ $\mathrm{C}$ in $140 \mu \mathrm{l}$ buffer after which reaction was started by addition of $10 \mu \mathrm{l}$ purified Agkistrodon halys halys activator. Final reaction conditions were: $50 \mathrm{mM}$ Tris/ $\mathrm{HCl}(\mathrm{pH} 7.9$ at room temp), $0.5 \mathrm{mM}$ EDTA, $1 \mathrm{mg} / \mathrm{ml}$ ovalbumin, $7.7 \mathrm{ng}$ purified activator and amounts of protein $\mathrm{C}$ as indicated in the. Figure. The initial rate of protein $\mathrm{C}$ activation was determined as described in the legend to figure 3 . (A) rate of protein $\mathrm{C}$ activation as a function of the protein $\mathrm{C}$ concentration. (B) Lineweaver-Burk plot of the same data. Further details are given under EXPERIMENTAL PROCEDURES.

Table 4. Kinctic parameters of protein $\mathrm{C}$ activation by the activator purified from Agkistrodon halys halys venom. Kinetic parameters of protein $\mathrm{C}$ activation were obtained at $37^{\circ} \mathrm{C}$ as described under EXPERIMENTAL. PROCEDURES and under the legend to Figure 5. In the case of human protein $C$ activation at $\mathrm{I}=0.15$ rates of $\mathrm{APC}$ formation were linear with respect to protein $\mathrm{C}$ concentration and from the observed reaction rates the second-order rate constant, which equals $k_{\text {cat }} / K_{\mathrm{m}}$, was calculated. Further details are given in the text.

\begin{tabular}{|c|c|c|c|}
\hline Substrate & $\begin{array}{c}k_{\text {cat }} \\
\left(\mathrm{s}^{-1} \pm \mathrm{s} . \mathrm{e}\right)\end{array}$ & $\begin{array}{c}K_{\mathrm{m}} \\
(\mu \mathrm{M} \pm \text { s.e. })\end{array}$ & $\begin{array}{c}k_{\mathrm{cat}} / K_{\mathrm{m}} \\
\left(\mathrm{M}^{-1} \mathrm{~s}^{-1} \pm \text { s.e. }\right)\end{array}$ \\
\hline \multicolumn{4}{|l|}{ Human protein $\mathrm{C}$} \\
\hline$I=0.05$ & $0.17 \pm 0.007$ & $0.52 \pm 0.04$ & $3.3( \pm 0.4) \times 10^{5}$ \\
\hline $\bar{I} \equiv 0.15$ & n.d. & n.d: & $3.4( \pm 0.3) \times 10^{4}$ \\
\hline \multicolumn{4}{|l|}{ Bovine protein $\mathrm{C}$} \\
\hline $\mathbf{I}=0.10$ & $0.24 \pm 0.006$ & $0.056 \pm 0.004$ & $4.3( \pm 0.4) \times 10^{6}$ \\
\hline
\end{tabular}


reaction medium that did not contain $\mathrm{NaCl}$. It was not possible to obtain kinetic parameters at high $\mathrm{NaCl}$ concentrations since we were not able to saturate the activator with human protein $\mathrm{C}\left(K_{\mathrm{m}}>2 \mu \mathrm{M}\right)$ and from the observed rate of APC formation the second-order rate constant $\left(k_{\mathrm{cat}} / K_{\mathrm{m}}\right)$ was calculated to be $4.3 \times 10^{4} \mathrm{M}^{-}$ $1_{\mathrm{s}} \mathrm{s}^{-1}$ at $50 \mathrm{mM} \mathrm{NaCl}$.

The activation of bovine protein $\mathrm{C}$ has more favorable kinetic parameters. At $50 \mathrm{mM} \mathrm{NaCl}$ a $V_{\max }$ of $10.4 \mathrm{nM} \mathrm{APC} / \mathrm{min}$ and a $K_{\mathrm{m}}$ of $0.056 \mu \mathrm{M}$ were obtained at $0.026 \mu \mathrm{g} / \mathrm{ml}$ activator which yields a $k_{\text {cat }}$ of $0.24 \mathrm{~s}^{-1}$ and a $k_{\text {cat }} / K_{\mathrm{m}}$ of $4.3 \times 10^{6} \mathrm{M}^{-1} \mathrm{~s}^{-}$ 1. The latter value indicates that at $50 \mathrm{mM} \mathrm{NaCl}$ bovine protein $\mathrm{C}$ is activated with a 100 -fold higher catalytic efficiency than human protein C. The kinetic parameters obtained in the experiments discussed above are summarized in Table 4. 


\section{DISCUSSION}

In the present paper we have described the purification and the characterization of a protein $\mathrm{C}$ activator from the venom of Agkistrodon halys halys. The activator is a single chain protein with an apparent molecular weight of 36,000 . The protein $\mathrm{C}$ activator and the purified protein were positively identified to be one and the same protein by transblotting the purified protein after SDS-PAGE to nitrocellulose and subsequently visualizing of the protein $\mathrm{C}$ activator on the nitrocellulose with protein C and the protein C-specific substrate S2366 (Figure 1). This positive identification is important since in case of the protein $\mathrm{C}$ activator from Agkistrodon contortrix contortrix there has been some discussion about the molecular weight of the activator and the number of activators present in the venom (cf. refs Klein and Walker, 1986 and Orthner et al., 1988). Moreover, in our case protein $\mathrm{C}$-activating activities eluted in single peaks during the various steps of the purification procedure and thus we did not find evidence that Agkistrodon halys halys venom might contain more than one protein $\mathrm{C}$ activator.

The protein C activator from Agkistrodon halys halys hydrolysed several tripeptide-p-nitroanilide substrates and its activity was readily inhibited by p-NPGB and PPACK which identifies the activator as a serine protease. The activator converted both human and bovine protein $\mathrm{C}$ into APC by removal of a small polypeptide fragment from the heavy chain of protein $C$. It is very likely that protein $\mathrm{C}$ activation by the venom activators from different $\mathrm{Agkistrodon}$ species is the result of cleavage of the same peptide bond in protein $\mathrm{C}$ that is also cleaved by thrombin (Kisiel, 1979) yielding products with the same functional activity.

Whereas the rate of hydrolysis of tripeptide-p-nitroanilide substrates by the activator was not affected by variation of the $\mathrm{Ca}^{2+}$ and $\mathrm{NaCl}$ concentrations in the reaction medium there was considerable inhibition of human protein $\mathrm{C}$ activation in activation mixtures which contained $\mathrm{Ca}^{2+}$ ions or high $\mathrm{NaCl}$ concentrations. Fifty percent inhibition of human protein $\mathrm{C}$ activation by the venom activator was observed at $0.8 \mathrm{mM} \mathrm{CaCl}$ and $20 \mathrm{mM} \mathrm{NaCl}$, respectively. Kinetic studies at low ionic strength $(\mathrm{I}=0.05)$ in the absence of $\mathrm{Ca}^{2+}$ ions revealed an apparent $K_{\mathrm{m}}$ for human protein $\mathrm{C}$ of $0.52 \mu \mathrm{M}$ and a $k_{\text {cat }}$ of $0.17 \mathrm{~s}^{-1}$ from which a catalytic efficiency $\left(k_{\mathrm{cat}} / K_{\mathrm{m}}\right)$ of $3.3 \times 10^{5} \mathrm{M}^{-1} \mathrm{~s}^{-1}$ can be calculated. Increasing the ionic strength to 0.1 caused a 10-fold decrease of $k_{\mathrm{cat}} / K_{\mathrm{m}}\left(4.3 \times 10^{4} \mathrm{M}^{-1} \mathrm{~s}^{-1}\right)$ which is at least partially due to an effect of ionic strength on the $K_{\mathrm{m}}$ for protein $\mathrm{C}$ which becomes $>2 \mu \mathrm{M}$.

The properties discussed thus far indicate that the protein $\mathrm{C}$ activator from 
Agkistrodon halys halys is remarkably similar to the protein $\mathrm{C}$ activators from Agkistrodon contortrix contortrix (Kisiel et al., 1987a; Kisiel et al., 1087b; Orthner et al., 1988) and Agkistrodon bilineatus (Nakagaki et al., 1990) with respect to molecular weight, catalytic efficiencies of human protein $\mathrm{C}$ activation and the inhibitory effects of $\mathrm{Ca}^{2+}$ ions and high $\mathrm{NaCl}$ concentrations. Differences between the amidolytic activities on tripeptide-p-nitroanilide substrates and different sensitivities towards serine protease inhibitors shows, however, that there are still some differences between the protein $\mathrm{C}$-activating proteases from the various Agkistrodon species. Such intra and subspecies variation of the structure and function of venom components are very typical for snakes belonging to the genus Agkistrodon (Chippaux et al., 1991).

A major difference between the protein $\mathrm{C}$ activators from Agkistrodon halys halys and Agkistrodon contortrix contortrix was observed in studies of bovine protein $\mathrm{C}$ activation. In the case of the activator from Agkistrodon contoririx contoririx activation of both human and bovine protein $\mathrm{C}$ were strongly inhibited by $\mathrm{Ca}^{2+}$ ions and by high $\mathrm{NaCl}$ concentrations under our experimental conditions. Human protein $\mathrm{C}$ activation by the activator from Agkistrodon halys halys was also very sensitive to the presence of $\mathrm{Ca}^{2+}$ ions $\left(K_{\mathrm{i}}=0.8 \mathrm{mM}\right)$ and to the $\mathrm{NaCl}$ concentration $\left(K_{\mathrm{i}}=20 \mathrm{mM}\right)$. However, with bovine protein $\mathrm{C}$ much higher $\mathrm{CaCl}_{2}$ and $\mathrm{NaCl}$ concentrations are required in order to observe inhibtion ( $c f$. Figs 3,4). These observations indicate that there are considerable differences between human and bovine protein $\mathrm{C}$ on one hand and between the venom protein $\mathrm{C}$ activators on the other hand.

Orthner et al. (1988) advanced the hypothesis that $\mathrm{Ca}^{2+}$ ions and $\mathrm{NaCl}$ change the conformation of protein $\mathrm{C}$ in such a way that it becomes a less favorable substrate for the protein $\mathrm{C}$ activator. Considering the experiments reported in the present paper and pursuing the proposal of Orthner and coworkers results in a complex picture with different conformations for human and bovine protein $\mathrm{C}$ at high $\mathrm{Ca}^{2+}$ and $\mathrm{NaCl}$ that are recognised by one, activator (Agkistrodon halys halys) and not by the other activator (Agkistrodon contortrix contortrix). It is, however, also possible that other effects contribute to the observed calcium and ionic strength dependence of venom-catalyzed protein $\mathrm{C}$ activation. Strong effects of ionic strength on chemical reactions are often taken to implicate that ionic (electrostatic) forces play an essential role in the interactions between the reacting substances. In the case of protein $\mathrm{C}$ activation by the venom activators this would mean that ionic interactions between protein $\mathrm{C}$ and the venom activator may have an important 
contribution to the formation of the enzyme-substrate complex and the subsequent proteolysis. Considering the properties of protein $\mathrm{C}$ and the venom activators from the various Agkistrodon species this will likely be an ionic interaction between a negatively charged domain on protein $\mathrm{C}$ and a positively charged protein domain on the venom activator. Such an interaction will be prevented both at increased ionic strength and also by $\mathrm{Ca}^{2+}$ ions, since this will reduce the negative charge of protein $\mathrm{C}$ by binding to the $\gamma$-carboxyglutamic acid residues. Depending on the net electrostatic charges of the protein domains involved in the interactions between protein $\mathrm{C}$ and the activator this may result in different $\mathrm{Ca}^{2+}$ ion and ionic strength effects on reactions between protein C's and venom activators from different species. In this respect it interesting to mention that there is a high degree of divergence in the amino acid sequences of human and bovine protein $\mathrm{C}$ around the peptide bond that is cleaved during protein $C$ activation (Foster and Davie, 1984). It is obvious, however, that more detailed studies will be required to gain more insight in these differences between human and bovine protein $\mathrm{C}$.

Finally we would like to emphasize that it is of interest to study the functional properties of the protein $\mathrm{C}$ activators present in the venoms of other Agkistrodon species. Our experiments indicate that these protein $\mathrm{C}$ activators may exhibit a number of important functional differences. It is, therefore, possible that other Agkistrodon species contain a protein $\mathrm{C}$ activator whose activity on human protein $\mathrm{C}$ is not inhibited by $\mathrm{Ca}^{2+}$ ions and high $\mathrm{NaCl}$ concentrations. Such an activator will be the preferred enzyme in a diagnostic test for the quantitation of plasma protein $\mathrm{C}$.

\section{ACKNOWLEDGEMENTS}

This work was supported in part by a grant from the Committee Cooperation Eastern Europe of the Duch Organization for Scientific Research (NWO). 



\section{The effect of phospholipids, calcium ions and protein $S$ on rate constants of human factor Va inactivation by activated human protein $\mathrm{C}$}

\section{ABSTRACT}

Rate constants for human factor $\mathrm{Va}$ inactivation by activated human protein $\mathrm{C}$ (APC) were determined in the absence and presence of $\mathrm{Ca}^{2+}$ ions, protein $\mathrm{S}$ and varying concentrations of phospholipid vesicles of different lipid composition. APCcatalyzed factor $\mathrm{Va}$ inactivation in free solution (in the presence of $2 \mathrm{mM} \mathrm{Ca}^{2+}$ ) was studied under first order reaction conditions with respect to both APC and factor Va and was characterized by an apparent second order rate constant of $6.1 \times 10^{5} \mathrm{M}^{-1} \mathrm{~s}^{-1}$. Stimulation of APC-catalyzed factor Va inactivation by phospholipids was dependent on the concentration and composition of the phospholipid vesicles. Optimal acceleration (230-fold) of factor Va inactivation was observed with $10 \mu \mathrm{M}$ phospholipid vesicles composed of 20 mole \% diolecylphosphatidylserine (DOPS) and 80 mole\% dioleoylphosphatidylcholine (DOPC). At higher vesicle concentrations and at higher mole fractions DOPS some inhibition of APC-catalyzed factor $\mathrm{Va}$ inactivation was observed. Membranes that contained anionic phospholipids other than phosphatidylserine also promoted factor Va inactivation. The ability of different anionic lipids to enhance factor Va inactivation increased in the order phosphatidylethanolamine < oleic acid < phosphatidic acid < phosphatidylglycerol < phosphatidylmethanol < phosphatidylserine. AFC-catalyzed factor $\mathrm{Va}$ inactivation in the presence of phospholipid vesicles could be saturated with respect to factor $\mathrm{Va}$ and the reaction obeyed Michaelis-Menten kinetics. Both the $K_{\mathrm{m}}$ for factor $\mathrm{Va}$ and the $V_{\max }$ of factor Va inactivation were a function of the phospholipid concentration. The $K_{\mathrm{m}}$ increased from $1 \mathrm{nM}$ at $2.5 \mu \mathrm{M}$ phospholipid (DOPS/DOPC; $20 / 80, \mathrm{~mol} / \mathrm{mol}$ ) to $65 \mathrm{nM}$ at $250 \mu \mathrm{M}$ phospholipid. The $V_{\max }$ increased from $20 \mathrm{nM}$ factor $\mathrm{Va}$ inactivated $/ \mathrm{min} / \mathrm{nM}$ APC at $2.5 \mu \mathrm{M}$ phospholipid to $62 \mathrm{nM}$ factor $\mathrm{Va}$ inactivated $/ \mathrm{min} / \mathrm{nM} \mathrm{APC}$ at $10 \mu \mathrm{M}$ phospholipid and remained constant at higher phospholipid concentrations. Protein $\mathrm{S}$ appeared to be a rather poor stimulator of APC-catalyzed factor Va inactivation. Protein S-dependent rate 
enhancements were only observed in reaction mixtures that contained negatively charged phospholipid vesicles. Independent of the concentration and the lipid composition of the vesicles, protein S caused a 2-fold stimulation of APC-catalyzed factor Va inactivation. This suggests that, in the human system, enhancement of APC binding to phospholipid vesicles by protein $\mathrm{S}$ is of minor importance. Considering that protein $\mathrm{S}$ is a physiologically essential antithrombotic agent, it is likely that other factors or phenomena contribute to the in vivo antithrombotic action of protein $\mathrm{S}$. 


\section{INTRODUCTION}

Protein $\mathrm{C}$ and protein $\mathrm{S}$ are vitamin $\mathrm{K}$-dependent plasma proteins that play an important role in the feedback regulation of thrombin generation (Esmon, 1989). The physiological importance of protein $\mathrm{C}$ and protein $\mathrm{S}$ is demonstrated by patients who are deficient in one of these proteins and who are suffering from recurrent thrombosis (Griffin et al., 1981; Branson et al., 1983; Schwarz et al., 1984; Seligsohn et al., 1984; Comp et al., 1984; Griffin, 1988). Protein C circulates in the blood as the zymogen of a proteolytic enzyme which is activated by the thrombin/thrombomodulin complex (Esmon and Owen, 1981). Activated protein C (APC) is a $57 \mathrm{kD}$ serine protease with specific proteolytic activity toward factor $\mathrm{Va}$ and factor VIIla (Walker et al., 1979; Vehar and Davie, 1980; Marlar et al., 1982; Fulcher et al., 1984). Inactivation of factor $\mathrm{Va}$ is accompanied by limited proteolysis of the factor Va heavy chain (Suzuki et al., 1983, Odegaard and Mann 1987, Van de Waart et al., 1984). The activity of factor VIIla is also lost upon cleavage of its heavy chain by APC (Vehar and Davie, 1980; Fulcher et al., 1984).

Optimal expression of the anticoagulant activity of APC requires the presence of the protein cofactor, protein $\mathrm{S}$, and negatively charged phospholipid membranes and calcium ions. Protein S was first isolated by DiScipio et al., (1977) as a new vitamin K-dependent protein which was later proposed to be a cofactor for APC (Walker 1980). The precise mechanisms of action of protein S in the APC reaction or as an antithrombotic factor are not yet clear. Proposed functions for protein S include: 1) promotion of APC binding to phospholipid membranes (Walker, 1981) and bovine platelets (Harris and Esmon, 1985) and 2) abrogation of the protection of factor Va by factor Xa from APC-catalyzed inactivation (Solymoss et al., 1988),

Negatively charged membranes are important in coagulation reactions by providing a surface that promotes the formation of functional enzyme-substrate complexes which considerably enhances the rates of coagulation factor activation (Rosing and Tans, 1988; Mann et al., Blood 1990). The inactivation of factor Va by APC was also reported to be accelerated by phospholipids which indicates that this reaction is also a membrane-associated process (Walker et al., 1979; Marlar et al., 1982; Walker, 1981; Van de Waart, 1984; Solymoss et al., 1988).

The present study concerns a detailed kinetic analysis of APC-catalyzed factor Va inactivation. We have determined the apparent second order rate constants of factor Va inactivation both in the absence and presence of protein $\mathrm{S}$ and varying concentrations of phospholipid vesicles of different lipid composition. The kinetic 
parameters $\left(K_{\mathrm{m}}\right.$ and $\left.V_{\max }\right)$ of factor Va inactivation by APC were measured as a function of the phospholipid concentration in order to get more information on the mode of interaction of the components of the protein $\mathrm{C}$ pathway. 


\section{EXPERIMENTAL PROCEDURES}

Materials - Bovine serum albumin, chicken egg albumin (ovalbumin), oleic acid, dioleoyl-sn-glycero-3-phosphocholine (DOPC), dioleoyl-sn-glycero-3phosphomethanol (DOPM), egg-yolk PC, brain PS, HEPES, MES and Tris were purchased from Sigma Chemical Co., St. Louis, MO, USA. The chromogenic substrates S2337, S2238 and S2366 and the thrombin inhibitor I-2581 were obtained from AB Kabi Diagnostica, Stockholm, Sweden. PPACK was from Calbiochem, La Jolla Ca. p-NPGB was purchased from Nutritional Biochemicals

Proteins - Proteins used in this study were purified from fresh frozen human plasma. Prothrombin and factor X were purified according to DiScipio et al., (1977). $\alpha$-thrombin was isolated from prothrombin activation mixtures in which purified prothrombin $\left(20 \mathrm{mg}\right.$ ) was activated at $37{ }^{\circ} \mathrm{C}$ in $10 \mathrm{ml}$ of a buffer solution containing $50 \mathrm{mM}$ Tris ( $\mathrm{pH} 7.5$ at $37^{\circ} \mathrm{C}$ ), $100 \mathrm{mM} \mathrm{NaCl}, 2 \mathrm{mM} \mathrm{CaCl}_{2}, 50 \mu \mathrm{M}$ phospholipid vesicles (brain PS/egg-yolk PC; 20/80, mol/mol), $2.5 \mathrm{nM}$ factor Xa, $40 \mathrm{nM}$ factor Va and $20 \mu \mathrm{M} \mathrm{I}-2581$. The reversible thrombin inhibitor I-2581 was present to prevent autocatalytic degradation of $\alpha$-thrombin. Prothrombin activation was complete within 10 min after which the $\alpha$-thrombin was purified from the reaction mixture as described by Pletcher and Nelsestuen (1982). Human protein C was prepared, activated and assayed as previously described by Gruber et al., (1989). APC was $>90 \%$ activated, as judged by SDS-polyacrylamide gel electrophoresis. The anticoagulant activity of APC ( $250 \mathrm{U} / \mathrm{mg}$ ) was equivalent to that of purified plasma protein C activated with Protac (Gruber $e$ al., 1989). Human protein $S$ was obtained from Enzyme Research Laboratories, South Bend, IN, USA. A reference protein S was purified following barium adsorption of normal plasma as described (Dählback, 1983). Factor Xa was obtained from purified factor $\mathrm{X}$ after activation with RVV-X and was isolated from the activation mixture by affinity chromatography on soybean trypsin inhibitor-Sepharose as described by Bock et al., (1989). Bovine factor Xa, which was used in the factor Va assay (see below), was purified as described by Fujikawa et al., (1972). RVV-X was purified from the crude venom of Russell's viper by the method of Schiffmann er al., (1969).

Factor V was purified essentially as described by Dahlbäck (1980) and by Suzuki et al., (1982). To fresh frozen human plasma the irreversible thrombin inhibitor PPACK was added to a final concentration of $2 \mu \mathrm{M}$. All buffer solutions used in the isolation procedure contained $250 \mathrm{nM}$ PPACK. The final purification step (chromatography on AcA-34) was performed with a buffer solution that did not 
contain PPACK. The presence of PPACK was necessary to obtain reproducible preparations of homogeneous and single chain factor $\mathrm{V}(>95 \%)$. Factor Va was prepared by activation of factor $\mathrm{V}$ with thrombin. Factor $\mathrm{V}(0.3 \mathrm{mg} / \mathrm{ml})$ was incubated for $30 \mathrm{~min}$ with $30 \mathrm{nM}$ thrombin in $50 \mathrm{mM}$ Tris (pH 7.9 at $20^{\circ} \mathrm{C}$ ) 175 $\mathrm{mM} \mathrm{NaCl}, 20 \%$ (v/v) glycerol and $5 \mathrm{mM} \mathrm{CaCl}_{2}$. After activation, $30 \mathrm{nM}$ PPACK was added in order to inhibit thrombin. The small amount of remaining PPACK did not interfere with the reactions carried out with the factor Va preparations. Factor Va was subsequently diluted $1 / 10$ in $25 \mathrm{mM}$ HEPES (pH 7.5 at room temperature), $126 \mathrm{mM} \mathrm{NaCl}, 2.68 \mathrm{mM} \mathrm{KCl}, 25 \mathrm{mM}$ glucose and $5 \mathrm{mg} / \mathrm{ml} \mathrm{BSA}$ and stored at -80 ${ }^{\circ} \mathrm{C}$. Factor Va was stable for several months at $-80{ }^{\circ} \mathrm{C}$ and lost about $10 \%$ of its activity when kept on ice for 6 hours.

Protein preparations were homogeneous and $>95 \%$ pure as judged by polyacrylamide gel electrophoresis in the presence of sodium dodecyl sulfate according to Laemmli (1970).

Protein concentrations - Protein concentrations were routinely determined according to Lowry et al., (1951) using BSA as a standard. Molar concentrations of thrombin and factor $\mathrm{Xa}$ were determined by active site titration with p-NPGB (Chase and Shaw, 1969; Smith, 1973). The APC concentration was determined with S2366 using kinetic parameters reported by Sala et al., (1984). Concentrations of factor Va were determined kinetically as described for bovine factor Va by Lindhout. el al., (1982).

Phospholipid and phospholipid vesicle preparations - 1,2-dioleoyl-sn-3phosphoserine (DOPS), 1,2-dioleoyl-sn-glycero-3-phosphoglycerol (DOPG), 1,2dioleoyl-sn-glycero-3-phosphate (DOPA.), and 1,2-dioleoyl-sn-glycero-3phosphoethanolamine (PE) were prepared from 1,2-dioleoyl-sn-glycerophosphocholine (DOPC) by enzymatic synthesis as described by Comfurius and Zwaal (1977).

Vesicles of varying composition were made by mixing the desired quantities of lipids, dissolved in $\mathrm{CHCl}_{3} / \mathrm{CH}_{3} \mathrm{OH}(1 / 1, \mathrm{v} / \mathrm{v})$, in a small glass test tube. After drying under mild $\mathrm{N}_{2}$ flow, $1 \mathrm{ml}$ buffer containing $25 \mathrm{mM}$ HEPES (pH 7.5), 126 $\mathrm{mM} \mathrm{NaCl}, 2.68 \mathrm{mM} \mathrm{KCl}$ and $5 \mathrm{mM}$ glucose was added. After vigorous vortexing for 1 minute the formed liposomes were sonicated for 10 minutes at $4{ }^{\circ} \mathrm{C}$ using a MSE Mark II 150-W ultrasonic disintegrator set at $8 \mu \mathrm{m}$ peak to peak amplitude. Vesicles made of 20 mole $\%$ oleic acid and 80 mole \% DOPC were vortexed and sonicated at $60{ }^{\circ} \mathrm{C}$ and kept at room temperature prior to use.

The phospholipid vesicles used in the factor Va assay were prepared from a mixture of 10 mole \% brain-PS and 90 mole \% egg PC and made in a buffer 
containing $50 \mathrm{mM}$ Tris- $\mathrm{HCl}\left(\mathrm{pH} 7.9\right.$ at $\left.20^{\circ} \mathrm{C}\right)$ and $175 \mathrm{mM} \mathrm{NaCl}$, These vesicles were stored at $-80^{\circ} \mathrm{C}$ prior to use.

Factor Va assay - Factor Va was determined via its cofactor activity in the activation of prothrombin by factor $\mathrm{Xa}$. For convenience, bovine factor $\mathrm{Xa}$ was used in the assay. Amounts of factor $\mathrm{Xa}$, phospholipid vesicles and prothrombin present in the assay were such that the rate of prothrombin activation was linearly dependent on factor $\mathrm{Va}$, was constant in time, and was not influenced by small variations of the factor $\mathrm{Xa}$, phospholipid and prothrombin concentrations. In a typical experiment factor Va was quantitated as follows: to $230 \mu \mathrm{l}$ of a buffer solution (prewarmed at $37^{\circ} \mathrm{C}$ ) containing prothrombin and phospholipid, $10 \mu \mathrm{l}$ bovine factor Xa was added and after $15 \mathrm{~s}$ prothrombin activation was started with the addition of a $10 \mu \mathrm{l}$ aliquot containing factor $\mathrm{Va}$. Final concentrations reached in the reaction mixture were: 50 $\mathrm{mM}$ Tris (pH 7.9 at room temp), $175 \mathrm{mM} \mathrm{NaCl}, 2 \mathrm{mM} \mathrm{CaCl}_{2}, 5 \mathrm{nM}$ factor Xa, 20 $\mu \mathrm{M}$ phospholipid vesicles (10 mole $\%$ brain PS $/ 90$ mole $\%$ egg-yolk PC), $0.5 \mu \mathrm{M}$ prothrombin, $0.5 \mathrm{mg} / \mathrm{ml}$ ovalbumin and the factor Va from the aliquot. Prothrombin activation in the assay mixture was determined by measuring the amount of thrombin formed after 1 min using the chromogenic substrate S2238 (Rosing et al., 1980). The amount of thrombin generated in this assay was linearly dependent on factor $\mathrm{Va}$ (up to some $60 \mathrm{pM}$ factor Va present in the assay mixture) and from a calibration curve made with known amounts of factor $\mathrm{Va}$ the amount of factor $\mathrm{Va}$ present in the reaction mixture could be calculated.

Inactivation of factor $\mathrm{Va}$ by activated protein $\mathrm{C}$ - The rate of factor $\mathrm{Va}$ inactivation was determined in reaction mixtures of $350 \mu \mathrm{l}$ containing $10 \mathrm{mM}$ HEPES (pH 7.5), $136 \mathrm{mM} \mathrm{NaCl}, 2.68 \mathrm{mM} \mathrm{KCl}, 5 \mathrm{mM}$ glucose, $0.5 \% \mathrm{BSA}$ and phospholipid vesicles, protein $\mathrm{S}$ and factor $\mathrm{Va}$ at the desired concentration. Incubations were carried out in flat-bottom polystyrene tubes with a diameter of 0.9 $\mathrm{cm}$. Before the addition of $\mathrm{APC}$, three $10 \mu \mathrm{l}$ aliquots were withdrawn to determine factor Va (see below). Inactivation of factor Va was started by adding APC to the reaction mixture. The decrease in factor $V$ a activity was monitored in $10 \mu \mathrm{l}$ aliquots taken from the reaction mixture each 30 seconds over a period of $3.5 \mathrm{~min}$. From the progressive decline in factor $\mathrm{Va}$ activity the rate of factor $\mathrm{Va}$ inactivation, expressed as $\mathrm{nM}$ factor $\mathrm{Va}$ inactivated (Vi) per min per $\mathrm{nM}$ APC was calculated. The amount of APC added to the reaction mixtures was chosen such that the rate of factor Val inactivation was linear in time (less than $20 \%$ factor Va became inactivated) and proportional to the amount of APC present. 


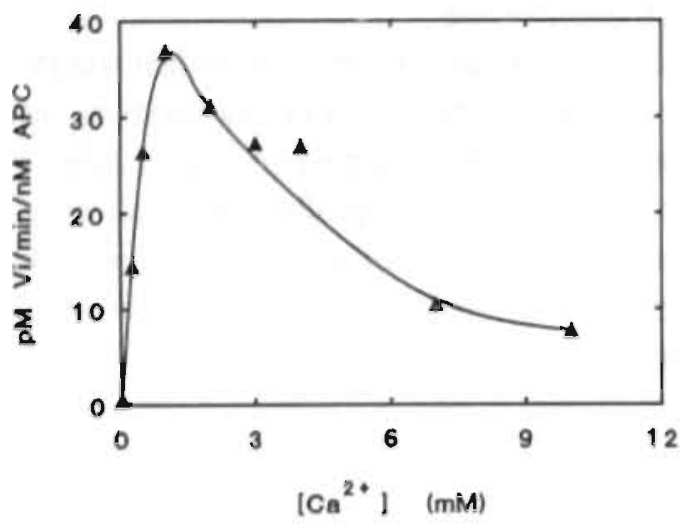

Figure 1. The effect of $\mathrm{Ca}^{2+}$ ions on the intial rate of $\mathrm{APC}$-catalyzed factor $\mathrm{Va}$ inactivation in free solution. Factor $\mathrm{Va}(1 \mathrm{nM})$ was inactivated by $2 \mathrm{nM} \mathrm{APC}$ at $37^{\circ} \mathrm{C}$ in a buffer containing $25 \mathrm{mM}$ HEPES (pH 7.5), $126 \mathrm{mM} \mathrm{NaCl}, 2.68 \mathrm{mM} \mathrm{KCl}, 5 \mathrm{mMl}$ glucose, $5 \mathrm{mg} / \mathrm{ml}$ BSA and concentrations of $\mathrm{CaCl}_{2}$ indicated in the figure. Initial rates of factor $\mathrm{Va}$ inactivation were determined as described under experimental procedures and the inactivation rates were expressed as $\mathrm{pM}$ factor $\mathrm{Va}$ inactivated $(\mathrm{pM} \mathrm{Vi)}$ per min per nM APC. If necessary the rates of factor Val inactivation were corrected for the spontaneous loss of factor $\mathrm{Va}$ activity occurring in the absence of APC.
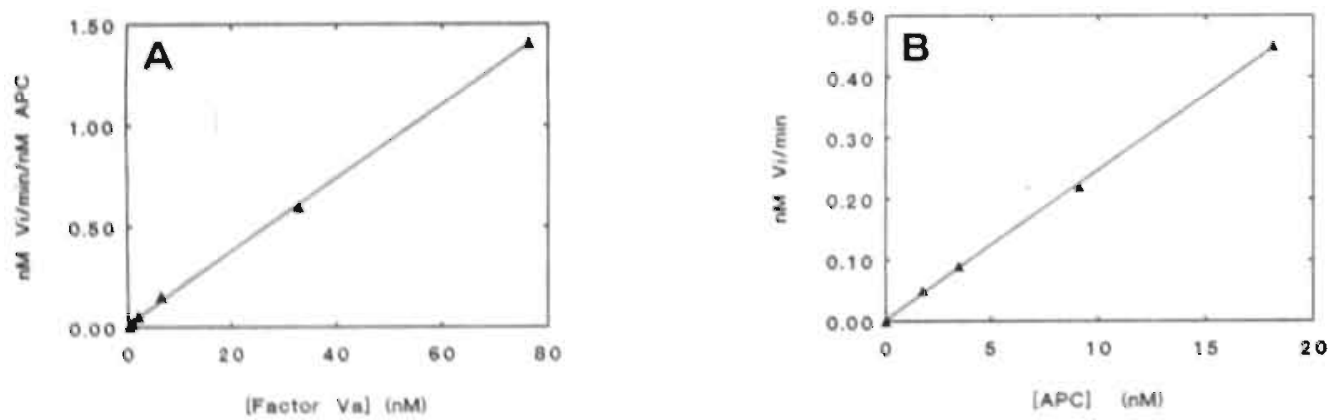

Figure 2. APC-catalyzed factor $\mathrm{Va}$ inactivation in free solution as a function of the concentrations factor $\mathrm{Va}$ and $\mathrm{APC}$. Factor $\mathrm{Va}$ was inactivated. by $\mathrm{APC}$ at: $37{ }^{\circ} \mathrm{C}$ in a buffer containing $25 \mathrm{mM}$ HEPES (pH 7.5), $126 \mathrm{mM} \mathrm{NaCl}, 2.68 \mathrm{mM} \mathrm{KCl}, 5 \mathrm{mM}$ glucose, $3 \mathrm{mM} \mathrm{CaCl}$ and $5 \mathrm{mg} / \mathrm{ml} \mathrm{BSA}$ at (A) concentrations of factor $\mathrm{Va}$ indicated in the figure and $9.6 \mathrm{nM}$ APC or (B) $1 \mathrm{nM}$ factor $\mathrm{Va}$ and concentrations of $\mathrm{APC}$ indicated in the figure. Initial rates of factor $\mathrm{Va}$ inactivation were determined as described under experimental procedures and the inactivation rates were expressed as $\mathrm{nM}$ factor Va inactivated per $\min (\mathrm{nM}$ Vi/min). 


\section{RESULTS}

Factor Va inactivation by $A P C$ in free solution - Limited information is available on the quantitative aspects of APC-catalyzed factor Va inactivation in free solution. Initially, it was reported that bovine factor Va inactivation by bovine APC was only observed in the presence of phospholipid (Kisiel et al., 1977), whereas later studies showed that there was no absolute phospholipid requirement (Walker et al., 1979). In order to appreciate the stimulatory effect of phospholipids we decided to start our investigations with a detailed kinetic study of the inactivation of human factor Va by human APC in free solution. This reaction appeared to require $\mathrm{Ca}^{2+}$ ions since in their absence no APC-dependent factor Va inactivation was observed. However, it should be mentioned that measurement of the inactivation rate without $\mathrm{Ca}^{2+}$ ions proved to be very difficult. Under these conditions factor Va looses its activity due to dissociation of the heavy and light chains (Esmon, 1979). Addition of $\mathrm{APC}$ to reaction mixtures without $\mathrm{Ca}^{2+}$ ions did, however, not result in acceleration of the spontaneous rate of factor $\mathrm{Va}$ inactivation. In the presence of $\mathrm{Ca}^{2+}$ ions spontaneous inactivation was greatly reduced and proceeded at a rate negligible to the APC-catalyzed reaction. Upon variation of the $\mathrm{Ca}^{2+}$ ion concentration maximal rates of APC-dependent factor $\mathrm{Va}$ inactivation were obtained at $2 \mathrm{mM} \mathrm{CaCl}_{2}$ (Fig. 1). A further increase of the $\mathrm{Ca}^{2+}$ ion concentration resulted in a gradual inhibition of factor $\mathrm{Va}$ inactivation.

The inactivation rate at optimal $\mathrm{CaCl}_{2}$ concentrations appeared to be linearly dependent on the concentration of factor Va $(0-78 \mathrm{nM})$ present in the reaction mixture (Fig. 2A). This shows that we were unable to saturate APC with its substrate factor $\mathrm{Va}$ and that under these conditions the $K_{\mathrm{m}}$ for factor $\mathrm{Va}$ is $>78 \mathrm{nM}$. The fact that we were not able to perform experiments at higher factor Va concentrations prohibited the use of Michaelis-Menten kinetics in the kinetic analysis of factor Va inactivation in free solution. Since the rate of factor $\mathrm{Va}$ inactivation was also linearly dependent on the concentration of APC (Fig. 2B), it was possible, however, to calculate the second order rate constant of the reaction. At $2 \mathrm{mM} \mathrm{CaCl}_{2}$ factor $\mathrm{Va}$ was inactivated with a second order rate constant of $6.1 \times 10^{5} \mathrm{M}^{-1} \mathrm{~s}^{-1}$. This rate constant was not affected by the presence of protein $\mathrm{S}$, which shows that protein $\mathrm{S}$ requires phospholipids to exert its cofactor function ( $c f$. Walker, 1980). 


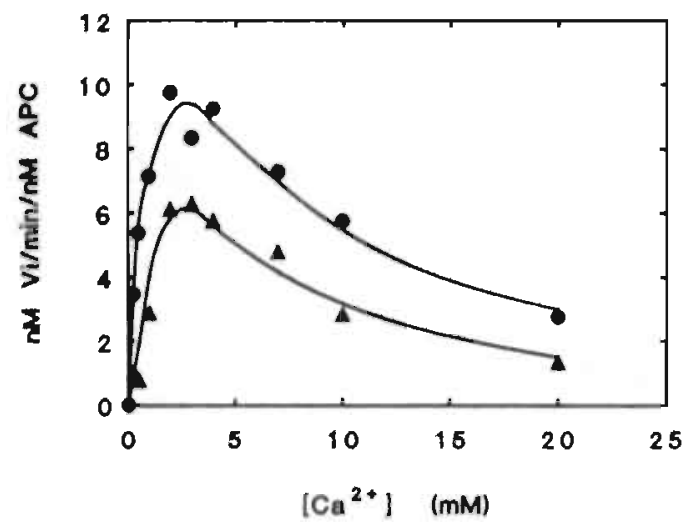

Figure 3. The effect of $\mathrm{Ca}^{2+}$ ions on the intial rate of $\mathrm{APC}$-catalyzed factor $\mathrm{Va}$ inactivation in the presence of phospholpids. Factor Va $(\mathbb{n} \mathrm{M})$ was inactivated by $15 \mathrm{pM} \mathrm{APC}$ in a buffer containing $25 \mathrm{mM}$ HEPES (pH 7.5), $126 \mathrm{mM} \mathrm{NaCl}, 2.68 \mathrm{mM} \mathrm{KCl}, 5 \mathrm{mM}$ glucose, $25 \mu \mathrm{M}$ phospholipid vesicles (20 mole $\%$ DOPS and 80 mole $\%$ DOPC), $5 \mathrm{mg} / \mathrm{ml} \mathrm{BSA}$, without protein S ( ) or with 70 $\mathrm{nM}$ protein $\mathrm{S}(\bullet)$. The concentrations of $\mathrm{CaCl}_{2}$ present are indicated in the figure. Initial rates of factor $\mathrm{Va}$ inactivation were determined as described under experimental procedures and the inactivation rates were expressed as $\mathrm{nM}$ factor $\mathrm{Va}$ inactivated per min per $\mathrm{nM}$ APC $(\mathrm{nM} \mathrm{Vi} / \mathrm{min} / \mathrm{nM}$ APC).

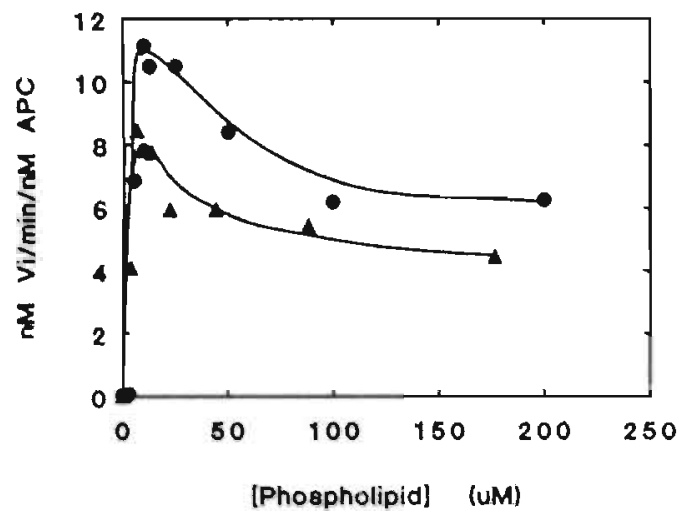

Figure 4. Inactivation of factor $\mathrm{Va}$ by $\mathrm{APC}$ at different phospholipid concentrations. Factor $\mathrm{Va}$ ( 1 $\mathrm{nM}$ ) was inactivated by $10 \mathrm{pM} \mathrm{APC}$ in a buffer containing $25 \mathrm{mM}$ HEPES ( $\mathrm{pH} 7.5$ ), $126 \mathrm{mM} \mathrm{NaCl}$,

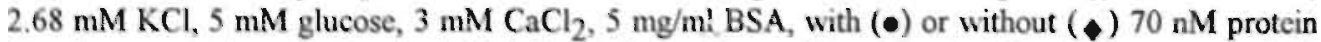
$\mathrm{S}$ and concentrations of phospholipid indicated in the figure. The phospholipid vesicles contained 20 mole $\%$ DOPS and 80 mole\% DOPC. Initial rates of factor $\mathrm{Va}$ inactivation were determined as described under experimental procedures and the inactivation rates were expressed as $\mathrm{nM}$ factor $\mathrm{Va}$ inactivated per min per $\mathrm{nM}$ APC ( $\mathrm{nM} \mathrm{Vi} / \mathrm{min} / \mathrm{nM}$ APC). 
Factor Va inactivation by APC in the presence of phospholipids APC-catalyzed factor $\mathrm{Va}$ inactivation has been reported to be considerably stimulated by the presence of negatively-charged membranes (Walker et al., 1979). Membrane-dependent factor Va inactivation also requires $\mathrm{Ca}^{2+}$ ions (Fig. 3). When rates of factor $\mathrm{Va}$ inactivation were determined as a function of the $\mathrm{Ca}^{2+}$ ion concentration in the presence of $25 \mu \mathrm{M}$ small unilamellar phospholipid vesicles composed of $20 \mathrm{~mole} \%$ DOPS and $80 \mathrm{~mole} \%$ DOPC, an optimum was observed at 2 $\mathrm{mM} \mathrm{CaCl}_{2}$ and at higher $\mathrm{Ca}^{2+}$ ion concentrations inhibition occurred. The presence of saturating amounts of protein $\mathrm{S}$ caused a 1.5 to 3 -fold stimulation of the rate of factor $\mathrm{Va}$ inactivation at all $\mathrm{Ca}^{2+}$ ion concentrations tested. Although the shape of the $\mathrm{Ca}^{2+}$ ion titration curves obtained in the presence of phospholipids and in free solution were similar it is likely that the mode of action of $\mathrm{Ca}^{2+}$ ions in the two reaction systems is different. It is generally accepted that phospholipid-dependent coagulation factor activation reactions require $\mathrm{Ca}^{2+}$ ions for the binding of vitamin $\mathrm{K}$-dependent coagulation factors (e.g. APC and protein S) to the membrane surface (Nelsestuen et al., 1978), whereas the $\mathrm{Ca}^{2+}$ ion requirement for the reaction in free solution is not yet understood.

Variation of the concentration of phospholipid vesicles (DOPS/DOPC; 20/80; $\mathrm{mol} / \mathrm{mol}$ ) showed that both with and without protein $\mathrm{S}$ an optimal rate of factor Va inactivation by $\mathrm{APC}$ was obtained at $10 \mu \mathrm{M}$ phospholipid and that some inhibition occurred at higher phospholipid concentrations (Fig. 4). The presence of protein S accelerated factor Va inactivation approximately 1.5 -fold independent of the phospholipid concentration present in the reaction mixture.

APC-catalyzed factor $\mathrm{Va}$ inactivation appeared to be dependent on the amount of negatively charged phospholipid (DOPS) present in the phospholpid vesicles (Fig. 5). When the mole percentage DOPS in DOPC vesicles was varied between 0 and $50 \mathrm{~mole} \%$ optimal rates of factor Va inactivation were obtained at 20 mole \% DOPS both in the absence and presence of protein S. A gradual inhibition was observed at mole percentages of DOPS $>20 \%$.

It was found that the stimulation of factor $\mathrm{Va}$ inactivation by phospholipids was not confined to membranes containing DOPS as anionic lipid. Phospholipid vesicles composed of DOPC with DOPA, DOPG or DOPM were also able to accelerate APC-catalyzed factor Va inactivation (Table 1). The activity of negatively charged membranes was not strictly dependent on the presence of a phosphate group since lipids which only contain a carboxyl moiety (oleic acid) also promoted factor $\mathrm{Va}$ inactivation. 
TABLE 1 Factor Va inactivation by activated protein $C$ (APC) on membranes containing different anionic phospholipids. Factor $\mathrm{Va}(1 \mathrm{nM})$ was inactivated by $\mathrm{APC}$ at $37^{\circ} \mathrm{C}$ in a reaction mixture containing $25 \mathrm{mM}$ HEPES (pH 7.5), $126 \mathrm{mM} \mathrm{NaCl}, 2.68 \mathrm{mM} \mathrm{KCl}, 3 \mathrm{mM} \mathrm{CaCl}$, $5 \mathrm{mM}$ glucose, 5 $\mathrm{mg} / \mathrm{ml} \mathrm{BSA}$ and $100 \mu \mathrm{M}$ phospholipid vesicles. Phospholipid vesicles were prepared from mixtures of $20 \mathrm{~mole} \%$ anionic lipid and $80 \mathrm{~mole} \%$ DOPC. Factor Va inactivation was started with $10-300$ $\mathrm{pM} A \mathrm{APC}$, depending on the reaction rate. The inactivation rate was expressed as $\mathrm{nM}$ factor Va inactivated per minute per $\mathrm{nM}$ APC.

\begin{tabular}{lc}
\hline Membrane composition & $\begin{array}{c}\text { Rate of FVa inactivation } \\
\text { (nM Vi/nM APC/min) }\end{array}$ \\
\hline No phospholipid & 0.037 \\
DOPC (100\%) & 0.034 \\
DOPE/DOPC $(20 / 80, \mathrm{~mol} / \mathrm{mol})$ & 0.12 \\
Oleic acid/DOPC $(20 / 80, \mathrm{~mol} / \mathrm{mol})$ & 0.34 \\
DOPADOPC $(20 / 80, \mathrm{~mol} / \mathrm{mol})$ & 1.50 \\
DOPG/DOPC $(20 / 80, \mathrm{~mol} / \mathrm{mol})$ & 2.16 \\
DOPS/DOPC $(20 / 80, \mathrm{~mol} / \mathrm{mol})$ & 4.70 \\
DOPM/DOPC $(20 / 80, \mathrm{~mol} / \mathrm{mol})$ & 4.71 \\
\hline
\end{tabular}

TABLE 2 The effect of accessory components on rate constants of APC-catalyzed factor Va inactivation. The rate constants were calculated from Figures 1 and 4. Phospholipid is $25 \mu \mathrm{M}$ DOPS/DOPC $(20 / 80, \mathrm{~mol} / \mathrm{mol})$.

\begin{tabular}{lc}
\hline $\begin{array}{l}\text { Factor Va inactivator } \\
\text { inactivation }\end{array}$ & Rate constant of FVa \\
& $\left(* 10^{5} \mathrm{M}^{-1} \mathrm{~s}^{-1}\right)$ \\
\hline $\mathrm{APC}$ & $<0.1$ \\
$\mathrm{APC}+\mathrm{Ca}^{2+}$ & 6.1 \\
$\mathrm{APC}+\mathrm{Ca}^{2+}+$ Protein S & 5.4 \\
$\mathrm{APC}+\mathrm{PL}^{2+}$ & $<0.1$ \\
$\mathrm{APC}+\mathrm{Ca}^{2+}+\mathrm{PL}$ & 1400 \\
$\mathrm{APC}+\mathrm{Ca}^{2+}+\mathrm{PL}+$ Protein S & 1900 \\
\hline
\end{tabular}




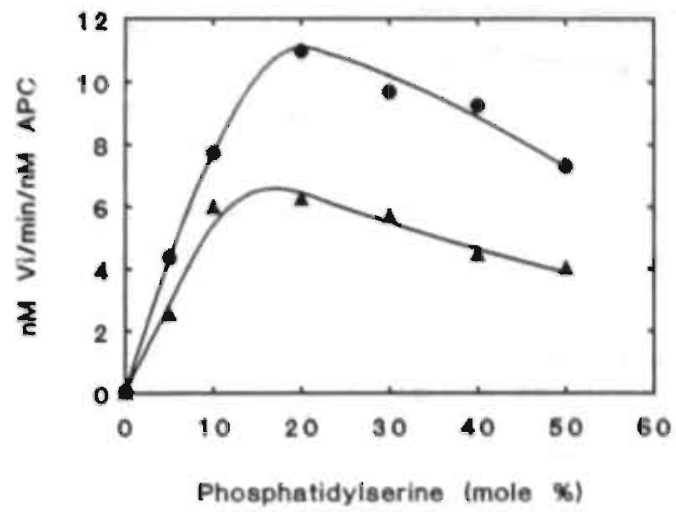

Figure 5. Inactivation of factor $\mathrm{Va}$ by $\mathrm{APC}$ in the presence of phospholipid vesicles containing varying amounts of phosphatidylserine. Factor $\mathrm{Va}(1 \mathrm{nM})$ was inactivated by $10 \mathrm{pM} \mathrm{APC}$ at $37^{\circ} \mathrm{C}$ in at buffer containing $25 \mathrm{mM}$ HEPES ( $\mathrm{pH} 7.5$ ), $126 \mathrm{mM} \mathrm{NaCl}, 2.68 \mathrm{mM} \mathrm{KCl}, 5 \mathrm{mM}$ glucose, $3 \mathrm{mM}$

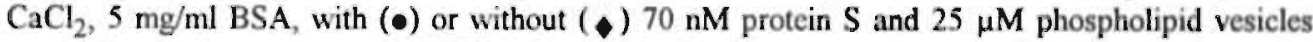
containing mole percentages DOPS indicated in the figure, supplementend with DOPC to 100 mole \%. Initial rates of factor $\mathrm{Va}$ inactivation were determined as described under experimental procedures and the inactivation rates were expressed as $\mathrm{nM}$ factor $\mathrm{Va}$ inactivated per min per $\mathrm{nM}$ APC (nM Vi/min/nM APC).

In order to quantitate the stimulatory effect of phospholipids we have calculated the apparent second order rate constants of factor Va inactivation at optimal $\mathrm{Ca}^{2+}$ ion and phospholipid concentrations and mole fraction DOPS and compared them with the rate constants obtained for the reaction in free solution (Table 2). These data indicate that phospholipids cause a more than 230-fold increase of the rate of APC-catalyzed factor Va inactivation. The addition of protein $S$ did not affect the reaction in free solution and caused marginal stimulation (1.4fold) of factor $\mathrm{Va}$ inactivation in the presence of phospholipid.

Kinetic parameters for APC-catalyzed factor Va inactivation in the presence of phospholipids - In contrast to the reaction in free solution (see above) phospholipid-dependent factor Va inactivation by APC could be saturated with respect to the factor Va concentration (Fig. 6A). Thus, it appears that the reaction obeyed Michaelis-Menten kinetics and, their kinetic parameters were obtained from a Lineweaver-Burk plot of the data (Fig. 6B). Using the statistical approach of Eisenthal and Cornish-Bowden (1974) a $K_{\mathrm{m}}$ for factor Va of $11.5 \mathrm{nM}$ and a $V_{\max }$ of 

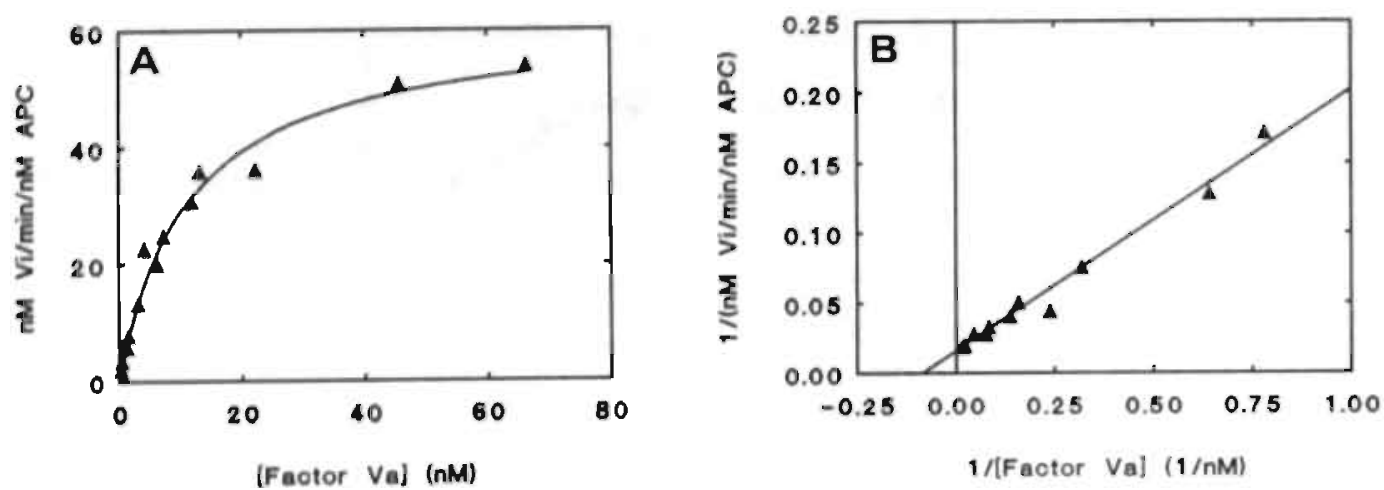

Figure 6. Substrate concentration dependence of APC-catalyzed factor $\mathrm{Va}$ inactivation in the presence of phospholipid. Factor Va, at concentrations indicated in the figure, was inactivated by $10-$ $45 \mathrm{pM}$ A.PC (dependent on the rate of inactivation) at $37^{\circ} \mathrm{C}$ in a buffer containing $25 \mathrm{mM}$ HEPES (pH 7.5), $126 \mathrm{mM} \mathrm{NaCl}, 2.68 \mathrm{mM} \mathrm{KCl}, 5 \mathrm{mM}$ glucose, $3 \mathrm{mM} \mathrm{CaCl}, 5 \mathrm{mg} / \mathrm{ml} \mathrm{BSA}$ and $50 \mu \mathrm{M}$ phospholipid vesicles ( $20 \mathrm{~mole} \%$ DOPS and $80 \mathrm{~mole} \%$ DOPC). Initial rates of factor $\mathrm{Va}$ inactivation were determined as described under experimental procedures and the inactivation rates were expressed as $\mathrm{nM}$ factor $\mathrm{Va}$ inactivated per min per $\mathrm{nM}$ APC (nM Vi/min/nM APC). (A) The rate of factor Va inactivation as a function of the factor Va concentration. (B) Lineweaver-Burk plot of the same data.
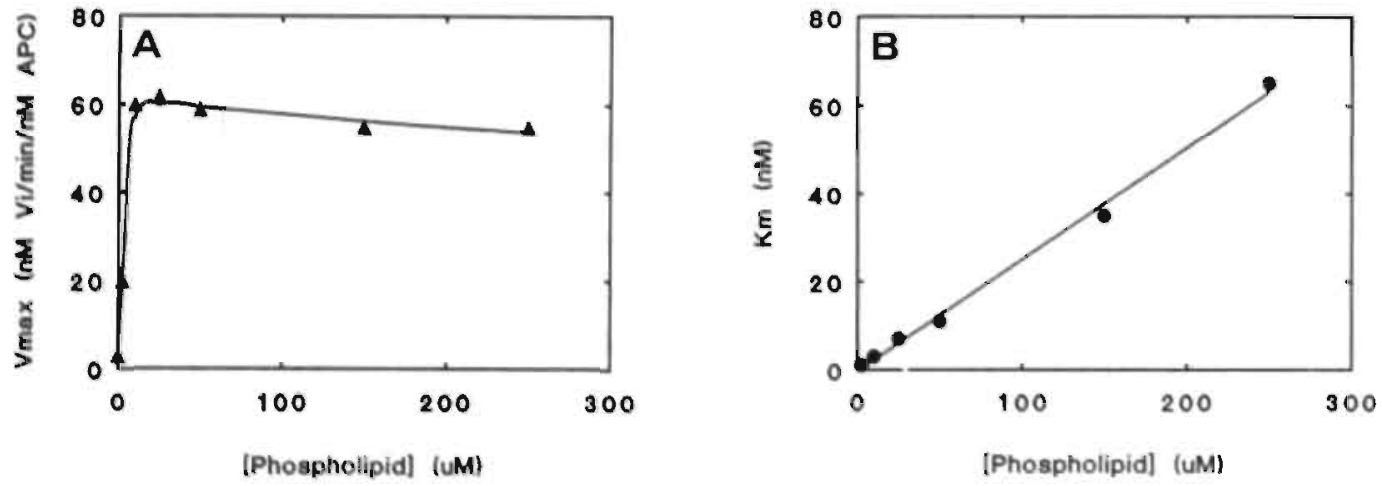

Figure 7. The kinetic parameters of APC-catalyzed factor $\mathrm{Va}$ inactivation as a function of phospholipid concentration. Varying concentrations of factor Va were inactivated by $10-45$ pM APC (dependent on the rate of inactivation) at $37^{\circ} \mathrm{C}$ in a buffer containing $25 \mathrm{mM}$ HEPES (pH 7.5), 126 $\mathrm{mM} \mathrm{NaCl}, 2.68 \mathrm{mM} \mathrm{KCl}, 5 \mathrm{mM}$ glucose, $3 \mathrm{mM} \mathrm{CaCl}, 5 \mathrm{mg} / \mathrm{ml} \mathrm{BSA}$ and concentrations of phospholipid vesicles (20 mole\% DOPS and 80 mole $\%$ DOPC) indicated in the figure. The kinetic parameters of APC-catalyzed factor Va inactivation were obtained from Lineweaver-Burk plots ( $c f$. figure 6). (A) The $K_{\mathrm{m}}$ for factor $\mathrm{Va}$ as a function of phospholipid concentration. (B) The $V_{\max }$ of factor Va inactivation (nM Vi/min/nM APC) as a function of phospholipid concentration. 
$61.9 \mathrm{nM} \mathrm{Va} / \mathrm{min} / \mathrm{nM} \mathrm{APC}$ were obtained for the inactivation of factor Va by APC on $50 \mu \mathrm{M}$ vesicles (DOPS/DOPC; $20 / 80, \mathrm{~mol} / \mathrm{mol}$ ). Since protein $\mathrm{S}$ had such a small effect (i.e. a 1.5 to 2 -fold rate enhancement) on factor $\mathrm{Va}$ inactivation we did not attempt to correlate the stimulatory effect of protein $\mathrm{S}$ with changes of the kinetic parameters.

Both kinetic parameters appeared to be a function of the phospholipid concentration present in the reaction mixture. The $V_{\max }$ increased from 20 to $62 \mathrm{nM}$ $\mathrm{Vi} / \mathrm{min} / \mathrm{nM}$ APC between 2.5 and $250 \mu \mathrm{M}$ phospholipid and approached a constant value at higher phospholipid concentrations (Fig. 7A). The $K_{\mathrm{m}}$ for factor Va was linearly dependent on the phospholipid concentration and varied between $1 \mathrm{nM}$ at $2.5 \mu \mathrm{M}$ phospholipid and $65 \mathrm{nM}$ at $250 \mu \mathrm{M}$ phospholipid (Fig. 7B). Similar effects of the phospholipid concentration on kinetic parameters have been observed for prothrombin and factor X activation (Rosing et al., 1980; van Dieijen et al., 1981). 


\section{DISCUSSION}

In this paper we have analyzed the effects of $\mathrm{Ca}^{2+}$ ions, phospholipids and protein $\mathrm{S}$ on the kinetic parameters of APC-catalyzed factor $\mathrm{Va}$ inactivation using purified human proteins. In agreement with earlier reports (Walker et al., 1979) we observed that factor $\mathrm{Va}$ inactivation by APC is not strictly dependent on the presence of phospholipids and protein $S$. The reaction in free solution does, however, require the presence of $\mathrm{Ca}^{2+}$ ions, and at the optimal $\mathrm{Ca}^{2+}$ ion concentration $(2 \mathrm{mM})$, the reaction proceeds with a second order rate constant of $6.1 \times 10^{5} \mathrm{M}^{-1} \mathrm{~s}^{-1}$. Since the inactivation rates were linearly dependent on the amount of factor Va present $(0-78 \mathrm{nM})$ we conlude that the reaction in free solution has a $K_{\mathrm{m}}$ for factor $\mathrm{Va}>78 \mathrm{nM}$. We have as yet no explanation for the calcium ion requirement of APC-catalyzed factor $\mathrm{Va}$ inactivation in the absence of phospholipids. Calcium ions may act either via factor Va or via $\mathrm{APC}$ or both since both proteins have the ability to interact with $\mathrm{Ca}^{2+}$ ions (Guinto and Esmon, 1982; Amphlett et al., 1981). Factor Va is composed of an equimolar complex of a heavy and light chain that are held together by a single $\mathrm{Ca}^{2+}$ ion (Guinto and Esmon, 1982). Since rates of APC-catalyzed factor $\mathrm{Va}$ inactivation were corrected for spontaneous loss of factor Va activity in the absence of calcium ions it is most likely that the site of $\mathrm{Ca}^{2+}$ ion involvement is on the enzyme. Bovine APC contains several $\mathrm{Ca}^{2+}$ binding sites associated with its Gla domain (Amphlett et al., 1981) and a Glaindependent high affinity calcium-binding site (Johnson et al., 1983). Both types of binding sites may be involved in $\mathrm{Ca}^{2+}$-induced transformation of APC into a functionally active enzyme. In this respect it should be mentioned that both the Gladependent and Gla-independent $\mathrm{Ca}^{2+}$-binding sites have to be occupied with $\mathrm{Ca}^{2+}$ ions to obtain optimal rates of activation of the protein $\mathrm{C}$ zymogen by the thrombinthrombomodulin complex (Esmon et al., 1982).

APC-catalyzed factor Va inactivation is greatly accelerated by negatively charged phospholipid vesicles. This stimulation appeared to be dependent on the phospholipid concentration and composition. Optimal rates of factor Va inactivation were obtained in the presence of $10 \mu \mathrm{M}$ phospholipid vesicles composed of 20 mole $\%$ DOPS and 80 mole \% DOPC. Under these reaction conditions APC-catalyzed factor Va inactivation was characterized by an apparent second order rate constant of $1.4 \times 10^{8} \mathrm{M}^{-1} \mathrm{~S}^{-1}$ which is about 230 -fold higher than the rate constant in free solution. To analyze the implications of such rate constants for the in vivo action of 
APC we have calculated rates of factor Va inactivation under conditions at which $1 \%$ of the amounts of protein $\mathrm{C}$ and factor $\mathrm{V}$ present in plasma are present in an activated form. Assuming that the plasma factor $\mathrm{V}$ concentration is $23 \mathrm{nM}$ (Tracy et al., 1982) and the protein C concentration is $65 \mathrm{nM}$ (Griffin et al., 1982), one can calculate that, under the conditions described above, the times required to inactivate $50 \%$ of the circulating factor $\mathrm{Va}$ are 29 and $0.13 \mathrm{~min}$ in the absence and presence of optimal phospholipid, respectively.

The stimulatory effect of phospholipids on APC-catalyzed factor Va inactivation exhibits a clear optimum both with respect to the phospholipid concentration and composition. At low phospholipid concentrations $(<10 \mu \mathrm{M})$ and low mole percentages DOPS $(<20 \mathrm{~mole} \%$ ) suboptimal rates of factor $\mathrm{Va}$ inactivation were obtained whereas at high phospholipid concentrations and high mole fractions DOPS some inhibition occurred. These phenomena are presumably a reflection of the mechanism by which the phospholipid membranes stimulate APCcatalyzed factor Va inactivation (see below). Membranes that were solely composed of the neutral phospholipid phosphatidylcholine were not able to accelerate APCcatalyzed factor $\mathrm{Va}$ inactivation. In order to stimulate factor Va inactivation, membranes have to carry a negative surface charge, i.e. contain anionic phospholipids. The ability to stimulate factor $\mathrm{Va}$ inactivation is not strictly confined to phosphatidylserine-containing membranes since membranes with other anionic phospholipids also considerably enhanced factor Va inactivation (Table 1). It is even not necessary that the membrane derives its negative charge from a phosphate group since membranes with oleic acid, which are negatively charged because of the presence of carboxyl groups, also stimulate APC-catalyzed factor Va inactivation.

The acceleration of APC-catalyzed factor $\mathrm{Va}$ inactivation by negatively charged membranes is presumably a reflection of the fact that both APC (Nelsestuen et al., 1978) and factor Va (Bloom et al., 1979) bind to such membranes. This allows the inactivation of membrane-bound factor Va by membrane-bound APC. Catalysis of reactions at a lipid-water interface is a characteristic feature of the coagulation cascade (Rosing and Tans, 1988; Mann el al., 1990). In such cases the presence of membranes profoundly changes the kinetic parameters of coagulation factor activations and inactivations. The $K_{\mathrm{m}}$ for the substrate is greatly decreased in the presence of phospholipid membranes and appears to be a function of the phospholipid concentration present in the reaction medium. When the concentration of phospholipid is increased there is a parallel increase of the $K_{\mathrm{m}}$ which is explained by the fact that the membrane-bound substrate molecules are diluted or bind to non- 
functional sites due to the increased amount of surface. Also the $V_{\max }$ of phospholipid-dependent reactions often appears to be a function of the phospholipid concentration. In general the $V_{\max }$ increases with the amount of phospholipid present and reaches a maximum at high phospholipid concentrations. The lipid dependency of $V_{\max }$ is a reflection of the binding of the enzyme to the membrane surface which increases at increasing surface concentration until at high surface concentration all enzyme is bound and participates in coagulation enzymatic reactions. The above described effects of membrane concentrations on $K_{\mathrm{m}}$ and $V_{\max }$ are also observed for APC-catalyzed factor Va inactivation ( $c f$. fig. 7) which strongly suggests that in the presence of phospholipid surface-bound factor $\mathrm{Va}$ is inactivated by surface-bound APC.

It is well established that protein $\mathrm{S}$, a vitamin $\mathrm{K}$-dependent protein, is required for the optimal expression of the anticoagulant activity of APC. The precise mechanisms of action of protein $\mathrm{S}$ as an antithrombotic or anticoagulant remains to be established. Original suggestions that the major function of protein $\mathrm{S}$ was to promote the binding of APC to phospholipids (Walker, 1981) and platelets (Harris and Esmon, 1985) were mainly based on experiments with bovine proteins. In studies with purified human proteins and human platelets, protein $\mathrm{S}$ appeared to be a rather poor stimulator of APC-catalyzed factor Va inactivation (Solymoss et al., 1988; Tans et al., 1991). In reaction systems containing purified human factor $\mathrm{Va}$, APC and phospholipid vesicles or platelets, protein $\mathrm{S}$ increased the rate of factor $\mathrm{Va}$ inactivation 1.5 to 2 -fold. It was also shown that factor Xa protects factor Va from inactivation by APC, an effect that is nullified by protein $\mathrm{S}$. Thus, when factor $\mathrm{Xa}$ is present in inactivation mixtures, the addition of protein $S$ causes a 5 to 10 -fold acceleration of APC-catalyzed factor Va inactivation.

The experiments reported in this paper also indicate clearly that in the human system the promotion of APC binding to membranes by protein $\mathrm{S}$ is of minor importance. We have shown that protein S stimulates APC-catalyzed factor Va inactivation approximately 2 -fold, independent of the phospholipid concentration or composition. In a model in which protein $S$ promotes the binding of APC to anticoagulant membranes one would expect that protein $S$ exerts its stimulatory effect preferentially at low phospholipid concentrations and on membranes with low amounts of phosphatidylserine, i.e. at conditions under which the rate of factor $\mathrm{Va}$ inactivation would be limited by the binding of APC to the membrane. The lack of such preferential stimulation ( $c f$. Figs. 4,5) supports the alternative theories that protein $\mathrm{S}$ abrogates the abilility of factor Xa to protect factor $\mathrm{Va}$ from inactivation 
by APC (Solymoss et al., 1988), that other proteins (e.g. a plasma protein S-binding protein) are required for full expression of protein $\mathrm{S}$ anticoagulant activity (Walker, 1986), and/or that protein $S$ possesses as yet undescribed anticoagulant properties.

\section{ACKNOWLEDGEMENTS}

We thank Dr. Mary-Jo Heeb and Dr. A Gruber for providing the human APC used in this study.

This work was supported by National Institute of Health Grant HL21544 and by the Netherlands Heart Foundation (M.C.L.G.D.T.) 



\section{Chapter 5}

\section{Functional Properties of Human Factor Va Lacking the Asp683-Arg709 Domain of the Heavy Chain}

\section{ABSTRACT}

A protease, purified from the venom of the elapid snake Naja naja oxiana, converts human blood coagulation factor $\mathrm{Va}$ into a molecule (designated factor $\left.\mathrm{Va}_{(N O)}\right)$ with greatly reduced cofactor activity. Polyacrylamide gel electrophoresis in the presence of sodium dodecyl sulphate revealed that the venom protease cleaves a small peptide from the heavy chain of factor Va and reduced it's apparent $\mathrm{MW}$ from 105,000 to 101,000 . Aminoacid sequence analysis indicated that the venom enzyme cleaved the peptide bond between $\mathrm{His}^{682}$ and $\mathrm{Asp}^{683}$ thus removing 27 amino acids from the carboxyterminal part of the heavy chain. The cofactor activities of factor $\mathrm{Va}$ and $\mathrm{Va}_{(\mathrm{NO})}$ were compared by measuring their abilities to support factor Xacatalyzed prothrombin activation in the presence of phospholipids and calcium ions. Both factor Va molecules stimulated the binding of factor $\mathrm{Xa}$ to negatively charged phospholipids. However, the amounts of factor Va required for half maximal incorporation of factor $\mathrm{Xa}$ into the membrane-bound factor $\mathrm{Xa}-\mathrm{Va}$ complex were much lower for native factor $\mathrm{Va}(0.25 \mathrm{nM})$ than for factor $\mathrm{Va}_{(N O)}(2.01 \mathrm{nM})$. At saturating concentrations factor $\mathrm{Va}$ or $\mathrm{Va}_{(N O)}$ both forms of factor Va yielded similar values for the $k_{\text {cat }}$ of prothrombin activation ( $114 \mathrm{~s}^{-1}$ for factor $\mathrm{Va}$ and $128 \mathrm{~s}^{-1}$ for factor $\left.\mathrm{Va}_{(N O)}\right)$. The $K_{\mathrm{m}}$ 's for prothrombin determined under these conditions were $0.24 \mu \mathrm{M}$ and $0.83 \mu \mathrm{M}$ for prothrombinase complexes with native factor $\mathrm{Va}$ and factor $\mathrm{Va}_{(N O)}$, respectively. Direct binding studies revealed that factor $\mathrm{Va}$ and $\mathrm{Va}_{(N O)}$ bind with equal affinity to phospholipids. These data indicate that factor $\mathrm{Va}_{(N O)}$ is impaired in its ability to interact with factor Xa and prothrombin. Together with the structural data this implies that the aminoterminal $\mathrm{Asp}^{683}-\mathrm{Arg}^{709}$ domain of the heavy chain is required for optimal interaction of factor $\mathrm{Va}$ with factor $\mathrm{Xa}$ and prothrombin. 


\section{INTRODUCTION}

Blood coagulation factor $\mathrm{V}$ is a single chain glycoprotein with a molecular weight of 330,000Da (Dahlbäck, 1980; Kane and Majerus, 1981) that contains three different types of protein domains (A, B and C) arranged in the order A1-A2-B-A3C1-C2 (Jenny et al., 1987; Cripe et al., 1992). Activation of human factor V by thrombin results in the removal of the major part of the $\mathrm{B}$ domain and the generation of factor $\mathrm{Va}$, a molecule that consists of a heavy chain (containing the A1, A2 and a small piece of the $\mathrm{B}$ domain) and a light chain (containing the A3, C1 and C2 domains) that are associated via a single $\mathrm{Ca}^{2+}$ ion (Esmon, 1979; Guinto and Esmon, 1982).

Factor $\mathrm{Va}$ is a non-enzymatic protein cofactor which together with the serine protease factor $\mathrm{Xa}, \mathrm{Ca}^{2+}+\mathrm{ions}$ and a procoagulant membrane surface forms the prothrombinase complex. Depending on the reaction conditions the presence of factor Va causes a $10^{3}-10^{6}$-fold stimulation of the rate of prothrombin activation (Nesheim ef al., 1979; Rosing et al., 1980). This rate enhancement appears to be due to 1) an increase of the catalytic activity $\left(k_{\text {cat }}\right)$ of the enzyme factor Xa (Nesheim et al., 1979; Rosing et al., 1980), 2) stimulation of the binding of factor Xa to phospholipid membranes (Nesheim et al., 1979; Lindhout et al., 1982; van Rijn et al., 1984) and 3) an increased interaction of the substrate prothrombin with the prothrombinase complex (van Rijn et al., 1984).

Snake venom proteins have been shown to be helpful tools in studying structure-function relationships of blood coagulation factors. Recently, we have purified a protease from the venom of Naja naja oxiana (Gerads et al., 1992) which is able to activate both human and bovine factor V. However, the factor Va molecule generated by this venom activator exhibited a much lower cofactor activity than thrombin-activated factor $\mathrm{V}$. Actually, the venom protease can also be regarded as a factor $\mathrm{Va}$ inactivator since incubation of thrombin-activated human factor Va with the venom protease resulted in $80-90 \%$ loss of cofactor activity.

In the present paper we describe the structural and functional properties of the factor Va derivative obtained after incubation of factor $\mathrm{Va}$ with the venom protease. It is shown that the protease cleaves a 27 amino acid peptide (Asp ${ }^{683}-\mathrm{Arg}^{709}$ ) from the carboxyterminal part of the heavy chain of factor $\mathrm{Va}$. The corresponding loss of cofactor activity appears to be due to impaired interaction of venom-treated factor $\mathrm{Va}$ with prothrombin and factor $\mathrm{Xa}$. 


\section{EXPERIMENTAL PROCEDURES}

Materials - Hepes, Tris, bovine serum albumin, chicken egg albumin (ovalbumin), soybean trypin inhibitor (type IS), bovine brain PS, egg-yolk PC and Russell's viper venom were purchased from Sigma Chemical Co., USA. DOPC and DOPS were obtained from Avanti Polar Lipids, Pelham, AL., USA. The chromogenic substrates S2238, S2337 and and the thrombin inhibitor 12581 were supplied by Chromogenix, Mölndal, Sweden. PPACK was obtained from Calbiochem and p-NPGB was from Nutritional Biochemicals. FPLC equipment and column materials used for protein purification were purchased from Pharmacia, Uppsala, Sweden.

Proteins - Human coagulation factors used in this study were purified from fresh frozen plasma. Human prothrombin and factor $\mathrm{X}$ were purified according to DiScipio et al. (1977). Human thrombin was prepared from prothrombin activation mixtures as described by Pletcher and Nelsestuen (1982). Human factor Xa was obtained from purified factor $\mathrm{X}$ after activation with RVV-X and isolation from the activation mixture by affinity chromatography on soybean trypsin inhibitorSepharose (Boch et al., 1989). RVV-X was purified from Russell's viper venom according to Schiffman et al. (1969). Human factor V was purified essentially as described by Dahlbäck (1980) with minor modifications (Tans et al., 1991b). Factor $\mathrm{Va}$ was obtained after activation of factor $\mathrm{V}$ with thrombin and separated from activation peptides on a prothrombin-CL4B-Sepharose column (Guinto and Esmon, 1984 ) and stored in a buffer containing $25 \mathrm{mM}$ Hepes ( $\mathrm{pH} 7.5$ ), $100 \mathrm{mM} \mathrm{NH}_{4} \mathrm{Cl}, 5$ $\mathrm{mM} \mathrm{CaCl} 2$ and $5 \mathrm{mg} / \mathrm{ml} \mathrm{BSA}$. The purified coagulation factors were stored at -80 ${ }^{\circ} \mathrm{C}$. Protein preparations were $>95 \%$ pure as judged by SDS-PAGE according to Laemmli (1970).

Protein Concentrations - Protein concentrations were determined according to Lowry et al. (1951). Molar thrombin and factor Xa concentrations werc determined by active site titration with p-NPGB (Chase and Shaw, 1969; Smith, 1973). Prothrombin concentrations were determined after complete activation of prothrombin with Echis carinatus venom and quantitation of thronabin with pNPGB. Factor $V$ concentrations were estimated from the absorbance at $280 \mathrm{~nm}$ using an $\mathrm{A}_{280} 1 \%$ of 8.9 (Kane and Majerus, 1981). Factor $\mathrm{Va}$ was quantitated as described below.

Amino-terminal sequence analysis - $200 \mu \mathrm{l}$ samples containing $6 \mu \mathrm{g}$ factor $\mathrm{Va}$ 
or $6 \mu \mathrm{g}$ factor Va treated with $0.06 \mu \mathrm{g}$ venom protease or $0.06 \mu \mathrm{g}$ venom protease were adsorbed onto Prospin filters and the filters were washed with methanol $/ \mathrm{H}_{2} \mathrm{O}$ (20/80). The samples were subsequentlty subjected to automated amino-terminal sequencing on an Applied Biosystems Model 476A Pulse Liquid Sequencer.

Phospholipid vesicle preparations - Appropriate quantities of phospholipids dissolved in chloroform/methanol $(1 / 1, \mathrm{v} / \mathrm{v})$ were mixed in a small glass tube. After drying under a mild flow of $\mathrm{N}_{2}$ the phospholipids were suspended in $2 \mathrm{ml}$ of a buffer containing $25 \mathrm{mM}$ Hepes $(\mathrm{pH} 7.5)$ and $175 \mathrm{mM} \mathrm{NaCl}$. The phospholipid suspension was vigorously vortexed for $1 \mathrm{~min}$ and subsequently sonicated for $10 \mathrm{~min}$ at $0{ }^{\circ} \mathrm{C}$ using a MSE Mark II 150-W ultrasonic disintegrator set at $8 \mu \mathrm{m}$ peak to peak amplitude. Phospholipid concentrations were determined by phosphate analysis (Böttcher et al., 1961).

Factor Va assay - Factor Va was quantitated by determining the rate of factor Xa-catalyzed prothrombin activation in reaction mixtures that contained a limiting amount of factor $\mathrm{Va}$ and saturating concentrations phospholipid vesicles $(50 \mu \mathrm{M}$ $\mathrm{PS} / \mathrm{PC}, 10 / 90, \mathrm{M} / \mathrm{M})$, factor $\mathrm{Xa}(5 \mathrm{nM})$ and prothrombin $(0.5 \mu \mathrm{M})$ (Tans el al., 1991b). The molar factor Va concentration in the assay mixture was calculated from the rate of prothrombin activation using a turnover number of 6000 moles prothrombin activated per min per mole of factor XaVa complex (Tans et al., 1991a). Molar factor $\mathrm{Va}_{(N O)}$ concentrations were calculated from and taken to be identical to the factor Va concentration initially present.

The assay conditions were modified in experiments in which differences in cofactor activity between factor $\mathrm{Va}$ and $\mathrm{Va}_{(N O)}$ were monitored. For optimal display of functional differences between factor $\mathrm{Va}$ and $\mathrm{Va}_{(\mathrm{NO})}$, the factor $\mathrm{Va}$ assay was performed at suboptimal factor Xa (0.5 nM), phospholipid (5 $\mu \mathrm{M} \mathrm{PS/PC,} \mathrm{5/95,}$ $\mathrm{M} / \mathrm{M})$ and prothrombin $(0.25 \mu \mathrm{M})$ concentrations (see legend to Figure 1 ).

Kinetic data analysis . The formation of a membrane-bound factor XaVa complex was determined by measuring rates of prothrombin activation in the presence of phospholipid vesicles at a fixed (limiting) concentration of factor $\mathrm{Xa}$ and varying amounts of factor $\mathrm{Va}$ or vice versa. Factor $\mathrm{Xa}$, factor $\mathrm{Va}$ and phospholipid vesicles were preincubated for 5 minutes at $37^{\circ} \mathrm{C}$ in $25 \mathrm{mM}$ Hepes $(\mathrm{pH} 7.5), 175$ $\mathrm{mM} \mathrm{NaCl}, 2 \mathrm{mM} \mathrm{CaCl} 2$ and $5 \mathrm{mg} / \mathrm{ml} \mathrm{BSA}$. Prothrombin activation was started by the addition of prothrombin (preincubated at $37{ }^{\circ} \mathrm{C}$ in the same buffer). Rates of prothrombin activation were determined with the chromogenic substrate S2238 (Rosing et al., 1980). The apparent $K_{\mathrm{d}}$ for dissociation of the membrane-bound factor Xa-Va complex $\left(\mathrm{K}_{1 / 2 \mathrm{Va}}\right)$ and the prothrombin-converting activity of this 
complex at [factor $\mathrm{Va}$ ] $\rightarrow \infty\left(V_{\mathrm{Va} \rightarrow \infty}\right)$ were obtained from a plots of the rate of prothrombin activation as function of the factor Va or Xa concentration that were fitted to the equation for a single site binding isotherm (hyperbola) via non-linear least squuares analysis.

The kinetic parameters ( $K_{\mathrm{m}}$ and $V_{\max }$ ) for factor Xa-catalyzed prothrombin activation were determined by measuring the rate of thrombin formation at varying prothrombin concentrations in the presence of a fixed phospholipid concentration, a limiting amount of factor $\mathrm{Xa}$ and a saturating concentration factor $\mathrm{Va}$ or $\mathrm{Va}_{(\mathrm{NO})}$ as described in the previous paragraph. The kinetic parameters were obtained by fitting the data to the Michaelis-Menten equation using non-linear least squares analysis.

Binding Studies - Binding parameters for factor Va-membrane association were determined on planar phospholipid bilayers. The free factor Va concentrations were determined with the functional assay described above and the concentrations of membrane-bound factor Va were determined by ellipsometry (Cuypers et al., 1983). Amounts of phospholipid-bound factor $V a$ were plotted as function of the free factor Va concentration and the binding parameters $\left(K_{\mathrm{d}}\right.$ and number of membrane binding sites) were obtained by non-linear least squares analysis of the data to the equation for a single site binding isotherm. 
TABLE 1. Amino-terminal sequences of factor Va before and after incubation with the venom protease from Naja naja oxiana. Human factor $\mathrm{Va}(30 \mu \mathrm{g} / \mathrm{ml})$ was incubated for 1 hour at $37^{\circ} \mathrm{C}$ in $25 \mathrm{mM}$ Hepes ( $\mathrm{pH} 7.5$ ), $175 \mathrm{mM} \mathrm{NaCl}, 2 \mathrm{mM} \mathrm{CaCl}{ }_{2}$ either in the absence or presence Naja naja venom protease $(0.3 \mu \mathrm{g} / \mathrm{ml})$. Both factor Va samples were subjected to amino-terminal sequencing as described under EXPERIMENTAL PROCEDURES.

\begin{tabular}{|c|c|c|c|c|c|c|}
\hline \multirow{3}{*}{$\begin{array}{l}\text { Cycle } \\
\text { no. }\end{array}$} & \multicolumn{3}{|c|}{ Factor Va } & \multicolumn{3}{|c|}{ Factor Va + Naja oxiana } \\
\hline & \multirow[b]{2}{*}{ Residue (pmol) } & \multicolumn{2}{|c|}{ FV-residues } & \multirow[b]{2}{*}{ Residue (pmol) } & \multirow{2}{*}{$\begin{array}{c}\text { New } \\
\mathrm{NH}_{2} \text {-terminus }\end{array}$} & \multirow{2}{*}{$\begin{array}{c}\text { FV-residues } \\
683-690^{\mathbf{a}}\end{array}$} \\
\hline & & $1-8^{\mathbf{a}}$ & $1546-1553^{\mathrm{a}}$ & & & \\
\hline \multirow[t]{3}{*}{1} & $\mathrm{~A}(31.1)$ & A & $S$ & A (30.5) & D & D \\
\hline & $S(14.4)$ & & & $S(15.4)$ & & \\
\hline & D $(22.9)$ & & & $\mathrm{D}(68.0)$ & & \\
\hline \multirow[t]{3}{*}{2} & $Q(29.6)$ & $Q$ & $\mathrm{~N}$ & $Q(39.6)$ & $\mathbf{R}$ & $\mathrm{R}$ \\
\hline & $N(15.6)$ & & & $\mathrm{N}(18.7)$ & & \\
\hline & & & & $R(10.6)$ & & \\
\hline \multirow[t]{2}{*}{3} & L (17.4) & $\mathrm{L}$ & $\mathrm{N}$ & $\mathrm{L}(22.7)$ & $\mathrm{L}$ & $\mathrm{L}$ \\
\hline & $N(20.3)$ & & & $N(19.7)$ & & \\
\hline \multirow[t]{3}{*}{4} & $R(19.1)$ & $\mathrm{R}$ & $\mathrm{G}$ & $\mathrm{R}(22.6)$ & $E$ & $\mathrm{E}$ \\
\hline & $G(16.6)$ & & & $\mathrm{G}(16.5)$ & & \\
\hline & & & & $E(13.4)$ & & \\
\hline \multirow[t]{3}{*}{5.} & $Q(16.1)$ & $Q$ & $\mathrm{~N}$ & $Q(19.7)$ & $\mathrm{P}$ & $P$ \\
\hline & $N(19.1)$ & & & $N(17.5)$ & & \\
\hline & & & & $P(15.5)$ & & \\
\hline \multirow[t]{2}{*}{6} & $F(13.4)$ & $\mathrm{F}$ & $\mathrm{R}$ & $F(14.6)$ & $E$ & $E$ \\
\hline & & & & $E(19.0)$ & & \\
\hline 7 & $Y(14,0)$ & $\mathbf{Y}$ & $\mathrm{R}$ & $Y(12.5)$ & - & $\mathrm{D}$ \\
\hline \multirow[t]{2}{*}{8} & V $(14.0)$ & V & $\mathrm{N}$ & V $(16.0)$ & $E$ & $\mathrm{E}$ \\
\hline & & & & E (19.8) & & \\
\hline
\end{tabular}

aFrom Jenny et al., 1987. 


\section{RESULTS}

Partial inactivation of factor Va by a protease purified from the venom of Naja naja oxiana - We recently purified an enzyme from the venom of Naja naja oxiana which converts thrombin-activated factor $\mathrm{V}$ (factor $\mathrm{Va}$ ) into a molecule with reduced cofactor activity (Gerads et al., 1992). The effects of the venom protease on the structure and function of human factor Va were monitored with a functional assay (Figure 1A) and with SDS-PAGE analysis (Figure 1B). Factor Va activity was determined via its ability to act as a cofactor in factor Xa-catalyzed prothrombin activation. To optimize the detection of functional differences between factor $\mathrm{Va}$ and venom-treated factor $\mathrm{Va}$ (further designated as factor $\mathrm{Va}_{(\mathrm{NO})}$ ) the activity assay was performed at suboptimal factor $\mathrm{Xa}$, prothrombin and phospholipid concentrations (Figure 1, see also under EXPERIMENTAL PROCEDURES). Incubation of factor $\mathrm{Va}$ with venom protease resulted in a rapid decrease of cofactor function until the activity reached a plateau at approximately $15 \%$ of the activity of native factor Va (Figure 1A). SDS-PAGE analysis of factor Va before (Figure 1B, left lane) and after incubation with venom protease (Figure $1 \mathrm{~B}$, right lane) shows that the heavy chain of factor $\mathrm{Va}_{(\mathrm{NO})}$ had a slightly increased electrophoretic mobility indicating the loss of a small peptide (MW 4kD) from the heavy chain.

Amino-terminal sequencing of factor $\mathrm{Va}$ and factor $\mathrm{Va}(\mathrm{NO})$ - To gain more insight in the localization of the cleavage site in the factor Va molecule we subjected factor $\mathrm{Va}$ to aminoterminal sequencing before and after complete reaction with Naja naja oxiana venom protease (Table 1). The sequence data obtained for native factor $\mathrm{Va}$ indicated the presence of two polypeptide chains with aminoterminal sequences that are in agreement with the aminoterminal sequence reported for the heavy and light chain of factor Va (Jenny et al., 1987).

After complete reaction of factor $\mathrm{Va}$ with venom protease an additional third aminoterminus (present in about equal amounts) could be deduced from the sequence data. This new aminoterminus does not originate from the venom enzym since the amounts of venom protein present in the reaction mixture were too low to be detectable in the sequence analysis. Thus we conclude that the newly formed aminoteminal sequence (D-R-L-E-P-E-?-E or Asp-Arg-Leu-Glu-Pro-Glu-?-Glu) originates from the polypeptide fragment that is removed from the heavy chain during incubation with the venom protease. This sequence yields a unique match with the published sequence of factor $\mathrm{V}(\mathrm{Va})$ at $\mathrm{Asp}^{683}$ through Glu ${ }^{690}$ (Jenny el al., 
A

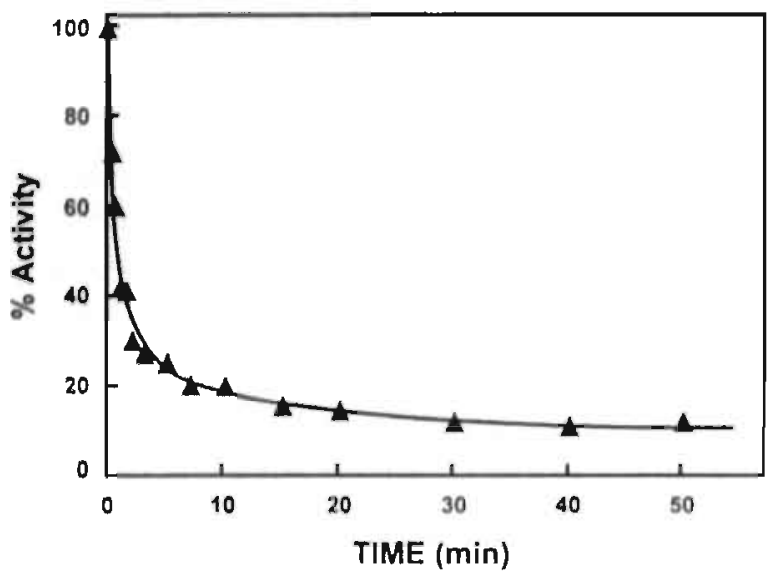

B

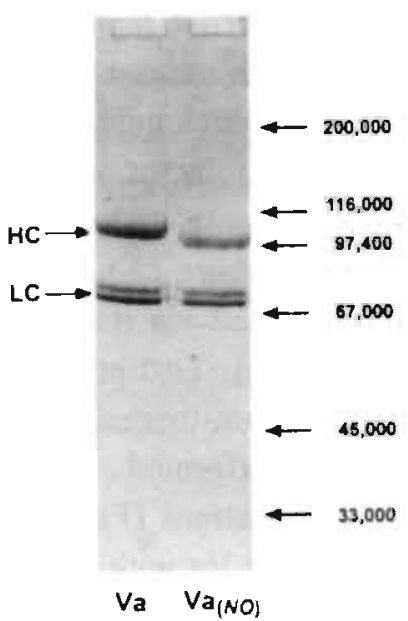

Figure 1. Effect of the Naja naja oxiana venom protease on human factor Va. Purified human factor $V a(200 \mu \mathrm{g} / \mathrm{ml})$ was incubated with purified Naja naja oxiana venom protease $(2 \mu \mathrm{g} / \mathrm{ml})$ in $250 \mu \mathrm{l} 25 \mathrm{mM}$ Hepes ( $\mathrm{pH} 7.5$ ), $175 \mathrm{mM} \mathrm{NaCl}$ and $5 \mathrm{mM} \mathrm{CaCl}_{2}$ at $37{ }^{\circ} \mathrm{C}$. A) At the indicated time points factor Va activity was determined in a reaction mixture containing $25 \mathrm{mM}$ Hepes (pH 7.5), $175 \mathrm{mM} \mathrm{NaCl}, 2 \mathrm{mM} \mathrm{CaCl}, 5 \mathrm{mg} / \mathrm{ml}$ bovine serum albumin, $0.5 \mathrm{nM}$ factor $\mathrm{Xa}, 0.25 \mu \mathrm{M}$ prothrombin, $5 \mu \mathrm{M}$ brain phosphatidylserine/egg yolk phosphatidylcholine $(5 / 95 ; \mathrm{M} / \mathrm{M})$. Further details of the assay procedure are described under EXPERIMENTAL PROCEDURES. B) Before addition of venom protease (lane identified as $\mathrm{Va}$ ) and after complete reaction $\left(50 \mathrm{~min}\right.$, lane $\left.\mathrm{Va}_{(\mathrm{NO})}\right) 25$ ul aliquots were taken for gel electrophoretic analysis on a $7.5 \%$ polyacrylamide slabgel $(5 \%$ stacking gel) in the presence of sodium dodecyl sulfate and $5 \%$ 2-mercaptocthanol (Laemmli, 1970). The positions of the Va heavy chain ( $\mathrm{HC}$ ) and the light chain doublet (LC) are indicated together with the positions of molecular weight markers run on a separate lane on the gel.

1987). We conclude, therefore, that incubation of factor Va with the purified protease from Naja naja oxiana venom resulted in cleavage of the peptide bond between His ${ }^{682}-\mathrm{Asp}^{683}$. Due to this cleavage a peptide of 27 amino acids (with a calculated MW of about 3140) is removed from the carboxyl terminal part of the heavy chain of factor $\mathrm{Va}$. This is in reasonable agreement with the change in apparent MW of the factor Va heavy chain observed in the SDS gels after reaction of factor Va with venom protease ( $c f$. Figure IB).

Functional properties of Naja naja oxiana-treated factor $\mathrm{Va}\left(\mathrm{Va} \mathrm{NO}_{\mathrm{N}}\right)$ Optimal cofactor activity of factor $\mathrm{Va}$ in prothrombin activation requires interaction 


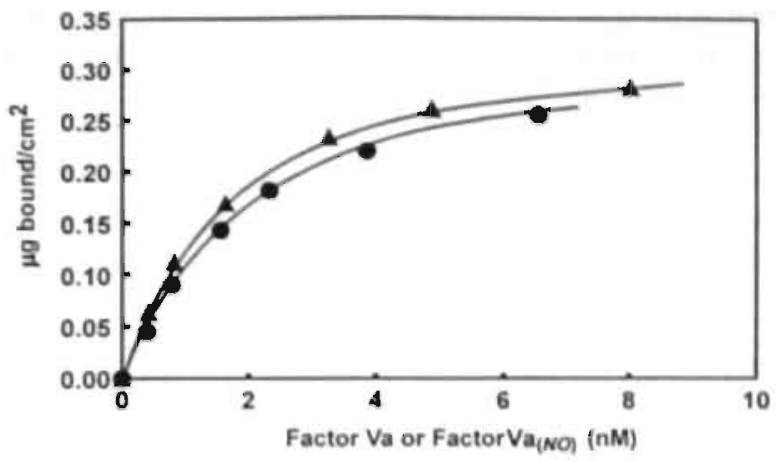

Figure 2. Binding of factor $\mathrm{Va}$ and $\mathrm{Va}_{(\mathrm{NO})}$ to planar phospholipid bilayers. Binding of factor $\mathrm{Va}(\bullet)$ and factor $\mathrm{Va}_{(N O)}(\sigma)$ to planar phospholipid bilayers (DOPS/DOPC, 20/80, M/M) was determined by ellipsometry (Cuypers et al,, 1983) in a buffer containing $25 \mathrm{mM}$ Hepes (pH 7.5 at $37{ }^{\circ} \mathrm{C}$ ), 175 $\mathrm{mM} \mathrm{NaCl}, 2 \mathrm{mM} \mathrm{CaCl}$ and $5 \mathrm{mg} / \mathrm{ml} \mathrm{BSA}$. The solid lines represent hyperbolas obtained by a nonlinear least squares fit of the data to a single site binding isotherm. The binding parameters describing these hyperbola are $K_{\mathrm{d}(\mathrm{Va})}=2.2 \mathrm{nM}$ and $0.34 \mu \mathrm{g}$ factor $\mathrm{Va}$ bound $/ \mathrm{cm}^{2}$ phospholipid at saturating factor $\mathrm{Va}$ or $\mathrm{Kd}_{\left(\mathrm{Va}_{\mathrm{O} O O)}\right)}=1.7 \mathrm{nM}$ and $0.35 \mu \mathrm{g}$ factor $\mathrm{Va}_{(\mathrm{NO})}$ bound $/ \mathrm{cm}^{2}$ phospholipid at saturating factor $\mathrm{Va}_{(N O)}$.
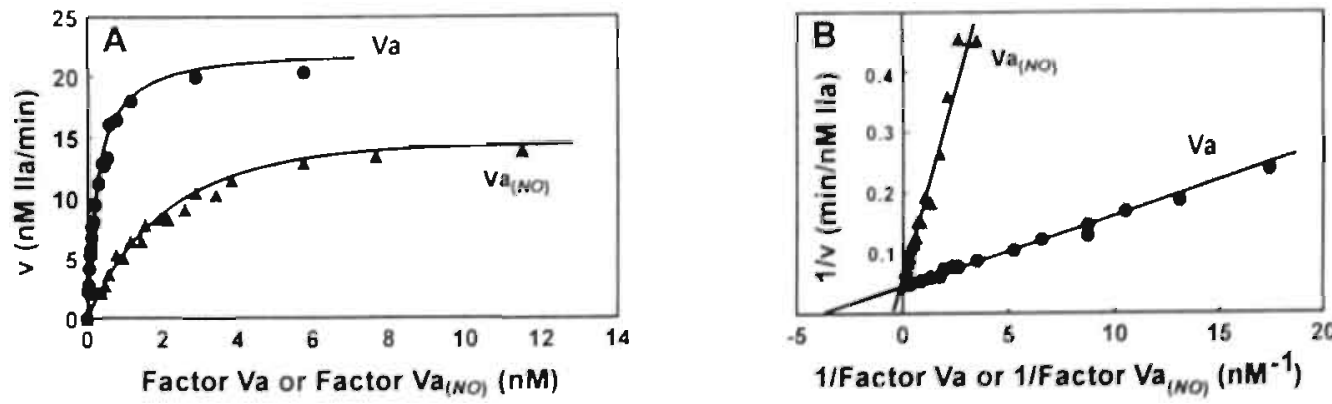

Figure 3. Comparison of cofactor activities of factor $\mathrm{Va}$ and $\mathrm{Va}_{(\mathrm{NO})}$. Initial rates of prothrombin activation were determined at a fixed, limiting concentration of factor $\mathrm{Xa}$ in $250 \mu \mathrm{l}$ buffer containing $25 \mathrm{mM}$ Hepes ( $\mathrm{pH} 7.5$ ), $175 \mathrm{mM} \mathrm{NaCl}, 2 \mathrm{mM} \mathrm{CaCl}, 5 \mathrm{mg} / \mathrm{ml} \mathrm{BSA}, 25 \mu \mathrm{M}$ phospholipid vesicles (DOPS/DOPC; $5 / 95 ; \mathrm{M} / \mathrm{M}$ ), $3 \mathrm{pM} \mathrm{Xa}, 1 \mu \mathrm{M}$ prothrombin and varying amounts of factor $\mathrm{Va}(\boldsymbol{\omega})$ or $\mathrm{Va}_{(\mathrm{NO})}(\sigma)$ as described in the EXPERIMENTAL. PROCEDURES. A) Rate of prothrombin activation as a function of factor $\mathrm{Va}$ or $\mathrm{Va}_{(\mathrm{NO})}$ concentration. The solid lines represent hyperbola obtained after

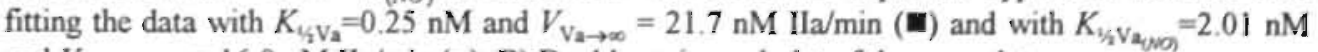
and $V_{\mathrm{Va}_{\mathrm{aNO}} \rightarrow \infty}=16.9 \mathrm{nM} \mathrm{Ila} / \mathrm{min}(\sigma)$. B) Double reciprocal plot of the same data. 
TABLE. 2. Comparison of functional properties of factor $\mathrm{Va}$ and $\mathrm{Va}_{(\mathrm{NO})}$. This table summarizes the different properties of factor $\mathrm{Va}$ and $\mathrm{Va}_{(\mathrm{NO})}$ obtained from the data presented in Figures 2-4. For details see text and the legends to the figures.

\begin{tabular}{lcc}
\hline & Factor Va & Factor Va \\
\hline$K_{\mathrm{dPL}}$ & $2.7 \mathrm{nM}$ & $1.7 \mathrm{nM}$ \\
$\left.K_{\mathrm{dXaVa}}{ }^{a}\right)$ & $0.25 \mathrm{nM}$ & $2.01 \mathrm{nM}$ \\
$K_{\mathrm{dXa \textrm {a }}}{ }^{\mathrm{b})}$ & $0.24 \mathrm{nM}$ & $2.27 \mathrm{nM}$ \\
$K_{\mathrm{m}}$ & $0.24 \mu \mathrm{M}$ & $0.83 \mu \mathrm{M}$ \\
$k_{\mathrm{cat}}$ & $114 \mathrm{~s}^{-1}$ & $128 \mathrm{~s}^{-1}$ \\
\hline
\end{tabular}

$K_{\mathrm{d} P \mathrm{y}}$, dissociation constant for membrane-factor $\mathrm{Va}$ or membrane-factor $\mathrm{Va}_{(\mathrm{NO})}$ complex (cf. Figure 2 ); $K_{\mathrm{d} \mathrm{XaVa}}$, apparent dissociation constant for the membrane-bound factor XaVa or $\mathrm{XaVa}_{(N O)}$ complex determined at limiting factor $\mathrm{Xa}^{\mathrm{a})}$ or limiting factor $\mathrm{Va} / \mathrm{Va}_{(N O}$ ) ${ }^{\text {b) }}$ concentrations (cf. Figure $3) ; K_{\mathrm{m}}$ and $k_{\text {cat }}$, kinetic parameters of prothrombin activation by the factor $\mathrm{XaVa}$ or factor $\mathrm{XaVa}_{(\mathrm{NO})}$ complex (cf. Figure 4).
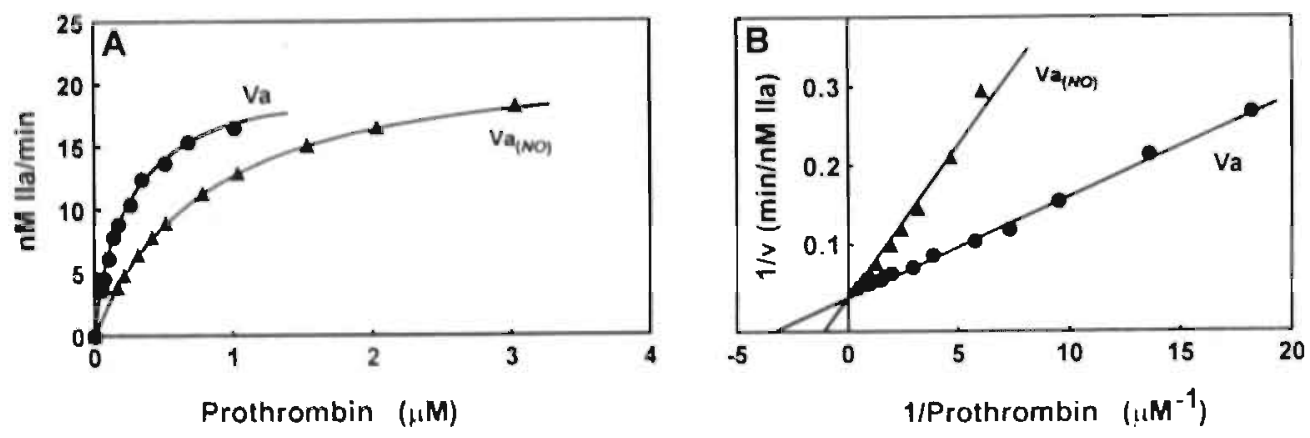

Figure 4. Prothrombin activation by $\mathrm{XaVa}$ and $\mathrm{XaVa}_{(N O)}$ as a function of prothrombin concentration. Initial rates of prothrombin activation were determined as described in the EXPERIMENTAL PROCEDURES at a fixed, limiting concentration of factor $\mathrm{Xa}$ in a reaction mixture containing $25 \mathrm{mM}$ Hepes (pH 7.5), $175 \mathrm{mM} \mathrm{NaCl}, 2 \mathrm{mM} \mathrm{CaCl}, 5 \mathrm{mg} / \mathrm{ml} \mathrm{BSA}, 25 \mu \mathrm{M}$ phospholipid vesicles (DOPS/DOPC; 5/95; M/M), $3 \mathrm{pM} \mathrm{Xa}$, saturating amounts of $\mathrm{Va}(5 \mathrm{nM}$, $\mathbf{m})$ or $\mathrm{Va}_{(\mathrm{NO})}$ (35 $\mathrm{nM}$, c) and varying amounts of prothrombin. A) initial rate of activation as a function of prothrombin concentration. The solid lines represent hyperbola with $K_{\mathrm{m}}=0.24 \mu \mathrm{M}$ and $V_{\max }=6860$ mole IIa/min/mole factor XaVa ( $\mathbf{D})$ and with $K_{\mathrm{m}}=0.83$ and $V_{\max }=7685 \mathrm{~mole} \mathrm{IIa/min} / \mathrm{mole}$ factor $\mathrm{XaVa}_{(\mathrm{NO})}(\sigma)$ which were obtained by fitting the data to the Michaelis-Menten equation using nonlinear least squares analysis. B) Lineweaver-Burk plots of the same data. 
of factor Va with procoagulant membranes, factor Xa and prothrombin. To examine which of these functions was impaired in Naja naja oxiana-treated factor Va we compared factor $\mathrm{Va}$ and factor $\mathrm{Va}_{(\mathrm{NO})}$ in direct binding studies and in a kinetic analysis of prothrombin activation.

Figure 2 shows an experiment in which we tested the ability of factor Va and $\mathrm{Va}_{(N O)}$ to bind to a planar lipid bilayer composed of 20 mole \% DOPS in DOPC. Factor $\mathrm{Va}$ and $\mathrm{Va}_{(N O)}$ bound equally well to the membrane and half maximal binding was observed at $2.2 \mathrm{nM}$ factor $\mathrm{Va}$ and $1.7 \mathrm{nM}$ factor $\mathrm{Va}_{(\mathrm{NO})}$. At saturating concentrations factor $\mathrm{Va}$ and $\mathrm{Va}_{(\mathrm{NO})}$ the amounts of bound protein were $0.34 \mu \mathrm{g}$ factor $\mathrm{Va} / \mathrm{cm}^{2}$ phospholipid and $0.35 \mu \mathrm{g}$ factor $\mathrm{Va}_{(\mathrm{NO})} / \mathrm{cm}^{2}$ phospholipid, respectively. Considering that $1 \mathrm{~cm}^{2}$ of a phospholipid bilayer contains $0.4 \mu \mathrm{g}$ phospholipid and that the molecular weights of factor Va and the phospholipid used are $\sim 180,000$ and $\sim 800 \mathrm{Da}$, respectively, it can be calculated that the phospholipid to factor Va ratio $(\mathrm{mol} / \mathrm{mol})$ at saturation is 265 for factor Va and 257 for factor $\mathrm{Va}_{(N O)}$. Thus, it appears that the cleavage in the factor Va heavy chain by Naja naja oxiana did not result in a change in lipid binding properties of the factor $\mathrm{Va}$ molecule. These data support the concept that it is the light chain region of factor $\mathrm{Va}$ that is actually responsible for lipid binding (van de Waart et al., 1983; Higgins and Mann, 1983; Pusey and Nelsestuen, 1984; Rosing et al., 1993).

To compare the ability of factor $\mathrm{Va}$ and $\mathrm{Va}_{(N O)}$ to assemble into a membranebound prothrombinase complex we determined initial steady state rates of prothrombin activation at a limited amount of factor $\mathrm{Xa}$ as a function of the factor $\mathrm{Va}$ or factor $\mathrm{Va}_{(\mathrm{NO})}$ concentration (Figure $3 \mathrm{~A}$ ). Low amounts of factor $\mathrm{Va}$ were required for full expression of prothrombinase activity whereas much higher amounts of $\mathrm{Va}_{(\mathrm{NO})}$ were needed in order to obtain similar activation rates. Halfmaximal prothrombinase complex formation was observed at $0.25 \mathrm{nM}$ and $2.01 \mathrm{nM}$ factor $\mathrm{Va}$ and factor $\mathrm{Va}_{(\mathrm{NO})}$, respectively. The double reciprocal plot shown in Figure $3 \mathrm{~B}$ shows that the intercepts at the $\mathrm{Y}$-axis were the same for both factor Va and $\mathrm{Va}_{(\mathrm{NO})}$ indicating that equal rates of prothrombin activation were obtained at saturating concentrations factor $\mathrm{Va}$ and $\mathrm{Va}_{(N O)}$. Thus, once formed both the factor $\mathrm{XaVa}$ and factor $\mathrm{XaVa}_{(\mathrm{NO})}$ complexes are equally capable of activating prothrombin.

With respect to the different cofactor activities of factor $\mathrm{Va}$ and $\mathrm{Va}_{(N O)}$, the possibility had to be ruled out that factor $\mathrm{Va}_{(\mathrm{NO})}$ lacks functional activity and that its cofactor activity is due to a small $(\sim 15 \%)$ remaining amount of factor Va. This possibility is excluded by the observations that a) titrations of fixed limiting amounts of factor $\mathrm{Va}$ or $\mathrm{Va}_{(\mathrm{NO})}$ with factor Xa yield $K_{\mathrm{d} \mathrm{XaVa}}$ of $0.24 \mathrm{nM}$ and $2.27 \mathrm{nM}$ for 
factor $\mathrm{XaVa}$ and $\mathrm{XaVa}_{(N O)}$ complexes, respectively (Table 2) and that b) a functional factor Va assay performed at saturating factor Xa $(5 \mathrm{nM})$, prothrombin (3 $\mu \mathrm{M}$ ) and phospholipid ( $50 \mu \mathrm{M}$ DOPS/DOPC, $20 / 80, \mathrm{M} / \mathrm{M}$ ) yield identical activities for factor $\mathrm{Va}$ and factor $\mathrm{Va}_{(N O)}$ (data not shown).

We also determined the kinetic parameters of prothrombin activation at a fixed factor $\mathrm{Xa}$ and phospholipid concentration and at saturating concentrations of factor $\mathrm{Va}$ or $\mathrm{Va}_{(\mathrm{NO})}$. Figure $4 \mathrm{~A}$ shows the rates of thrombin formation obtained for the factor $\mathrm{XaVa}$ and factor $\mathrm{XaVa}_{(N O)}$ complexes as a function of prothrombin concentration. From the Lineweaver-Burk plots shown in Figure $4 \mathrm{~B}$ it can be concluded that the reaction adhered to overall Michaelis-Menten kinetics. With factor XaVa the reaction was characterized by a $K_{\mathrm{m}}$ for prothrombin of $0.24 \mu \mathrm{M}$ and a $V_{\max }$ of $6860 \mathrm{~mol}$ prothrombin activated $/ \mathrm{min} / \mathrm{mole}$ factor Xa. This is in reasonable agreement with data reported earlier (Tans et al., 1991a; Rosing et al., 1993). In the case of the factor $\mathrm{XaVa}_{(N O)}$ complex the $K_{\mathrm{m}}$ was less favourable $(0.83 \mu \mathrm{M})$ whereas $V_{\max }$ was slightly higher ( $7685 \mathrm{~mol}$ prothrombin activated $/ \mathrm{min} / \mathrm{mole}$ factor $\mathrm{Xa}$ ). 


\section{DISCUSSION}

Factor Va exerts multiple effects in factor Xa-catalyzed prothrombin activation. The cofactor strongly increases the catalytic turnover $\left(k_{\text {cat }}\right)$ of the enzyme factor Xa and promotes the assembly of productive enzyme-substrate complexes at the procoagulant membrane by stimulating the binding of factor $\mathrm{Xa}$ and prothrombin to the membrane. Thus, it appears that factor $\mathrm{Va}$ is a multifunctional protein that promotes prothrombin activation via interaction with phospholipids, factor $\mathrm{Xa}$ and prothrombin. The phospholipid binding site of factor Va appears to be located on the light chain (van de Waart et al., 1983; Higgins and Mann, 1983; Pusey and Nelsestuen, 1984; Rosing et al., 1993), prothrombin has been reported to interact with the heavy chain (Guinto and Esmon, 1984), whereas both the heavy and light chain of factor Va have been implicated to interact with factor Xa (Guinto and Esmon, 1984; Tucker et al., 1983; Annamalai et al., 1987).

The data presented in this paper give additional insight into the domains of the Va molecule that are involved in the interaction with factor $\mathrm{Xa}$ and prothrombin. Using a protease purified from the venom of Naja naja oxiana we obtained a factor $\mathrm{Va}$ molecule (factor $\mathrm{Va}_{(\mathrm{NO})}$ ) that lacks 27 amino acid residues from the carboxylterminus of the heavy chain and that is further characterized by a greatly reduced cofactor activity.

Table 2 summarizes the functional properties of factor $\mathrm{Va}$ and factor $\mathrm{Va}\left(\mathrm{Va}_{(\mathrm{NO})}\right)$. Both factor $\mathrm{Va}$ and $\mathrm{Va}_{(N O)}$ bind equally well to negatively charged phospholipids. This is in agreement with earlier reports which indicate that the heavy chain of factor $\mathrm{Va}$ is not involved in membrane binding. The apparent $K_{\mathrm{d}}$ for XaVa complex. formation at the phospholipid membrane is, however, about an order of magnitude less favourable in the truncated factor $\mathrm{Va}_{(N O)}$ molecule (Table 2, Figure 3). This strongly suggests that the carboxyterminal residues of the heavy chain are important for the interaction of factor $\mathrm{Va}$ with factor $\mathrm{Xa}$. Once formed, the factor $\mathrm{XaVa}_{(\mathrm{NO})}$ complex also has somewhat less favourable kinetic parameters for prothrombin activation as evidenced by the increase in $K_{\mathrm{m}}$ for prothrombin (Table 2, Figure 4). The ability of factor Va to increase the enzymatic turnover $\left(k_{\mathrm{cat}}\right)$ of prothrombin activation is not affected in the factor $\mathrm{Va}_{(N O)}$ molecule (Table 2). Thus, the final 27 carboxylterminal residues of the factor Va heavy chain do not play a role in the increase of $k_{\text {cat }}$ of prothrombin activation but these residues are apparently involved in complex formation of factor $\mathrm{Va}$ with both factor $\mathrm{Xa}$ and prothrombin. 
The fact that the carboxylterminus of the factor Va heavy chain plays a role in protein-protein interactions between factor $\mathrm{Va}$ and other proteins can be appreciated on basis of the primary sequence of factor $\mathrm{V}(\mathrm{Va})$. The carboxyterminus of the heavy chain of factor Va is highly acidic (Jenny et al., 1087) and can, therefore, be expected to be at the surface of the molecule and to be readily available for interaction with other molecules. In this respect it is interesting to note that Kalafatis et al. (1990) recently reported that the heavy chain of bovine factor Va can be phosphorylated at $\mathrm{Ser}^{690}$ and that this phosphorylation renders the molecule more susceptible to inactivation by activated protein $C$. No data were given, however, on the effect of phosphorylation on the interaction of factor $\mathrm{Va}$ with factor $\mathrm{Xa}$ or prothrombin. Whether such phosphorylation can also occur in the human molecule is as yet also unknown. The literature data emphasise, however, that this region of the factor Va heavy chain is accessible for interaction with other macromolecules and plays an important role in the expression and regulation of factor Va cofactor activity.

The cleavage site at which the protease purified from Naja naja oxiana venom cleaves factor $\mathrm{Va}$ ( $\mathrm{His}^{682}$-Asp $^{683}$ ) is an unusual target site for proteolytic enzymes. There is, however, a report on an abnormal fibrinogen in which $\operatorname{Arg}^{16}$ of the $A \alpha$-chain is replaced by His ${ }^{16}$ and which appears to be cleaved quantitatively and selectively by thrombin after this histidine residue (Henschen and McDonagh, 1986). To our knowledge no other proteases have been identified which specifically cleave after a histidine residue. It is interesting, therefore, to further study this snake venom protease in order to gain more insight in the molecular basis for its proteolytic specificity.

\section{ACKNOWLEDGEMENTS}

We thank Rita Janssen and Dr. George Willems for performing the binding experiments on the ellipsometer. This work was supported by Program Grant 900526-192 from the Dutch Organisation for Scientific Research (NWO). Prof. L. Yukelson was supported by a grant from the Committee Cooperation Eastern Europe from the Dutch Organisation for Scientific Research (NWO). 



\section{Chapter 6}

\section{Characterization of two forms of human factor Va with different cofactor activities}

\section{ABSTRACT}

Factor $\mathrm{Va}$ is an essential cofactor in factor Xa-catalyzed prothrombin activation. Purified human factor Va appears to consist of a heavy chain (MW $\approx$ $105,000 \mathrm{Da}$ ) and a light chain doublet with $\mathrm{MWs}$ of $\approx 74,000 \mathrm{Da}$ and $\approx 71,000 \mathrm{Da}$, respectively. We separated factor $\mathrm{Va}$ by chromatography on a Mono $\mathrm{S}$ column into two fractions, designated factor $\mathrm{Va}_{1}$ and factor $\mathrm{Va}_{2}$. Factor $\mathrm{Va}_{1}$ contains the light chain with a $M W$ of $\approx 74,000 \mathrm{Da}$ and factor $\mathrm{Va}_{2}$ exclusively contains the light chain with a MW of $\approx 71,000 \mathrm{Da}$. The two forms of factor Va express different cofactor activities when prothrombin is activated at low phospholipid concentrations or on membranes containing low amounts of phosphatidylserine (PS) in phosphatidylcholine (PC). Compared with factor $\mathrm{Va}_{2}$, much higher amounts of factor $\mathrm{Va}_{1}$ are required for factor $\mathrm{XaVa}$ complex formation at the membrane surface. Once incorporated into the prothrombinase complex, factors $\mathrm{Va}_{1}$ and $\mathrm{Va}_{2}$ are equally active in prothrombin activation. This indicates that the two forms of factor $\mathrm{Va}$ do not differ in their ability to promote the catalytic activity of factor Xa or to interact with prothrombin. Direct binding experiments show that the different cofactor activities are explained by a greatly impaired ability of factor $\mathrm{Va}_{1}$ to bind to negatively charged membranes. Factor $V$ is also separated into two protein peaks after chromatography on Mono S column. Upon incubation with thrombin, the first peak yields factor $\mathrm{Va}_{1}$ and the second peak factor $\mathrm{Va}_{2}$. The same two forms of factor Va were generated when freshly prepared plasma samples or platelet suspensions were treated with thrombin. This shows that the heterogeneity of the light chain domain is an intrinsic property of both plasma and platelet factor V. It is hypothesized that the heterogeneity is caused by small differences in the carboxylterminal $\mathrm{C} 2$ domain of factor $\mathrm{V}$ that are introduced as the result of post-ribosomal processing . 


\section{INTRODUCTION}

Activated blood coagulation factor $\mathrm{V}$ (factor $\mathrm{Va}$ ) plays an essential role as cofactor in the conversion of prothrombin into thrombin by the serine protease factor $\mathrm{Xa}$. Factor Va accelerates factor Xa-catalyzed prothrombin activation four to five orders of magnitude by causing a 1000 -fold increase of the catalytic capacity $\left(k_{\text {cal }}\right)$ of factor Xa (Nesheim et al., 1979; Rosing el al, 1980) and by promoting the binding of both factor Xa and prothrombin to procoagulant membranes (Nesheim et al., 1979; Lindhout et al., 1982; van Rijn et al., 1984).

Factor $\mathrm{Va}$ is generated from the pro-cofactor, factor $\mathrm{V}$, which circulates in plasma as a single chain glycoprotein with a MW of about $330,000 \mathrm{Da}$ (Dahlbäck, 1980; Kane and Majerus, 1981). Factor V has little or no procoagulant activity (Nesheim et al, 1979) and is converted into factor Va after proteolysis of specific peptide bonds which among others can be catalyzed by thrombin (Dahlbäck, 1980; Kane and Majerus, 1981; Suzuki et al., 1982). Thrombin-activated factor V is a twochain molecule (Suzuki et al., 1982), that consists of a heavy chain and light chain held together by a tightly-bound calcium ion (Esmon, 1979; Guinto and Esmon, 1982). The heavy chainis derived from the amino-terminal region of factor $\mathrm{V}$ and has a MW of $105,000 \mathrm{Da}$. The light chain originates from the carboxyl-terminal region and appears on SDS-polyacrylamide gels as a doublet with apparent MWs of 71,000 and 74,000Da, both in case of human (Suzuki et al., 1982) and bovine factor Va (Nesheim et al., 1984; Odegaard and Mann, 1987).

There is as yet no good explanation for the heterogeneity of the light chain of factor Va. It is likely, however, that the structural basis for the light chain doublet has to be sought in its carboxyl-terminal region since large parts of the aminoterminal region of the light chain (with MW up to 62,000Da) appear as single bands after SDS-gelelectrophoretic analysis (Odegaard and Mann, 1987; Ortel et al., 1992).

In this paper we show that the heterogeneity of the carboxyl-terminal domain of the light chain region of factor $\mathrm{Va}$ is already observed in factor $\mathrm{V}$ present in fresh plasma and platelet samples. We further report the separation of factor Va into two fractions that are homogeneous with respect to their light chain composition. The factor Va preparation with the $71,000 \mathrm{Da}$ light chain is characterized by a more efficient incorporation in the prothrombinase complex than the factor Va that contains the light chain with $\mathrm{MW}=74,000 \mathrm{Da}$. This difference in cofactor function appears to be due to different binding affinities for procoagulant membranes. 


\section{EXPERIMENTAL PROCEDURES}

Materials - Bovine serum albumin, chicken egg albumin (ovalbumin), soybean trypin inhibitor (type IS), bovine brain PS, egg-yolk PC, Russell's viper venom, Hepes and Tris were purchased from Sigma Chemical Co., St Louis, MO., USA. DOPC and DOPS were obtained from Avanti Polar Lipids, Pelham, AL., USA. S2238, S2337 and 12581 were supplied by AB Kabi Diagnostica, Stockholm, Sweden. PPACK was obtained from Calbiochem and p-NPGB was from Nutritional Biochemicals. Column materials and FPLC equipment used for protein purification were purchased from Pharmacia, Uppsala, Sweden.

Proteins- The human coagulation factors used in this study were purified from fresh frozen plasma. Human prothrombin and factor $\mathrm{X}$ were purified according to DiScipio et al. (1977). Human thrombin was prepared from prothrombin activation mixtures by the method of Pletcher and Nelsestuen (1982). Human factor $\mathrm{Xa}$ was obtained from purified factor $\mathrm{X}$ after activation with RVV-X and isolation from the activation mixture by affinity chromatography on soybean trypsin inhibitorSepharose (Bock et al., 1989). RVV-X was purified from Russell's viper venom according to Schiffman et al. (1969). Human factor V was purified essentially as described by Dahlbäck (1980) with minor modifications (Tans et al., 1991). Factor Va was prepared by incubating factor $\mathrm{V}(0.3 \mathrm{mg} / \mathrm{ml})$ for $20 \mathrm{~min}$ with $30 \mathrm{nM}$ thrombin in a buffer containing $10 \mathrm{mM}$ Hepes (pH 7.5), $50 \mathrm{mM} \mathrm{NaCl}$ and $5 \mathrm{mM}$ $\mathrm{CaCl}_{2}$. After activation $60 \mathrm{nM}$ PPACK was added to inhibit thrombin. The factor Va preparation was subsequently applied to a $1 \mathrm{ml}$ prothrombin-CL4B-Sepharose column and eluted with a linear gradient of $50-500 \mathrm{mM} \mathrm{NH}_{4} \mathrm{Cl}$ in $10 \mathrm{mM}$ Hepes (pH 7.5). Factor $\mathrm{Va}$ eluted at $260 \mathrm{mM} \mathrm{NH}_{4} \mathrm{Cl}$. The factor Va containing fractions were pooled and diluted in a buffer containing $25 \mathrm{mM}$ Hepes $(\mathrm{pH} 7.5), 100 \mathrm{mM} \mathrm{NH}_{4} \mathrm{Cl}$, $5 \mathrm{mM} \mathrm{CaCl}_{2}$ and $5 \mathrm{mg} / \mathrm{ml} \mathrm{BSA}$. Prothrombin, factor $\mathrm{Xa}$, factor $\mathrm{V}$ and factor $\mathrm{Va}$ were stored at $-80{ }^{\circ} \mathrm{C}$. Protein preparations were homogeneous and $>95 \%$ pure as judged by SDS-PAGE according to Laemmli (1970).

Separation of the Two Forms of Factor Va (Factor Va, and Factor Va) - The factor Va obtained fron the prothrombin-CL4B-Sepharose column (see previous paragraph) was further subjected to fast protein liquid chromatography (FPLC) on a Mono S column (HR 5/5) at room temperature. The flow rate during the whole purification procedure was $0.5 \mathrm{ml} / \mathrm{min}$. After application of $0.6 \mathrm{mg}$ factor Va the column was washed with $15 \mathrm{ml}$ of a buffer containing $25 \mathrm{mM}$ Hepes (pH 7.5), 50 $\mathrm{mM} \mathrm{NH}{ }_{4} \mathrm{Cl}$ and $5 \mathrm{mM} \mathrm{CaCl}_{2}$. No factor $\mathrm{Va}$ activity eluted during the application 
and wash procedure. The Mono-S column was then developed with $15 \mathrm{ml}$ of a linear gradient $\left(50 \mathrm{mM}-1000 \mathrm{mM} \mathrm{NH}_{4} \mathrm{Cl}\right)$ in the same buffer. Factor Va activity eluted from the column in two well-separated protein peaks at $450 \mathrm{mM}$ and $750 \mathrm{mM}$ $\mathrm{NH}_{4} \mathrm{Cl}$, respectively. The first factor Va peak contained the light chain with $\mathrm{MW}=$ $74,000 \mathrm{Da}$ (factor $\mathrm{Va}_{1}$ ) and the second peak consisted of factor $\mathrm{Va}$ with a light chain with $\mathrm{MW}=71,000 \mathrm{Da}$ (factor $\mathrm{Va}_{2}$ ). The two factor $\mathrm{Va}$ containing peaks were pooled separately and contained pure and homogeneous factor Va as judged by SDS-PAGE according to Schägger and von Jagow (1987). In a large number of factor Va preparations isolated from different batches of human plasma the amount of protein present in peak 1 was about half of that present in peak 2.

Separation and identification of different factor $V$ forms present in purified factor $\mathrm{V}$ preparations and in plasma and platelet samples was accomplished by the same procedure and is described in the legends to the figures.

Gel Electrophoretic Techniques - Factor Va preparations and the activation patterns of factor $V$ activated with thrombin were analysed by SDS-PAGE in the presence of Tricine according to Schägger and von Jagow (1987). This electrophoretic technique has the advantage that the separation of protein bands in the gel is hardly affected by the ionic strength of the samples.

Protein Concentrations - Protein concentrations were determined according to Lowry et al. (1951). Molar thrombin and factor Xa concentrations were determined by active site titration with p-NPGB (Chase and Shaw, 1969; Smith, 1973). Prothrombin concentrations were determined after complete activation of prothrombin with Echis carinatus venom and quantitation of thrombin with pNPGB. Factor $V$ concentrations were estimated from the absorbance at $280 \mathrm{~nm}$ using an $A_{280} 1 \%$ of 8.9 (Kane and Majerus, 1981). Factor Va concentrations were determined as described by Lindhout et al. (1982).

Phospholipid vesicle preparations - Appropriate quantities of phospholipids dissolved in $\mathrm{CHCl}_{3} / \mathrm{CH}_{3} \mathrm{OH}(1 / 1, \mathrm{v} / \mathrm{v})$ were mixed in a glass tube and dried under a mild flow of $\mathrm{N}_{2}$. The phospholipids were suspended in $2 \mathrm{ml}$ buffer $(25 \mathrm{mM}$ Hepes, $\mathrm{pH} 7.5,175 \mathrm{mM} \mathrm{NaCl}$ ) and vigorously vortexed for $1 \mathrm{~min}$. The phospholipid suspension was subsequently sonicated for $10 \mathrm{~min}$ at $0{ }^{\circ} \mathrm{C}$ using a MSE Mark II $150-\mathrm{W}$ ultrasonic disintegrator set at $\$ \mu \mathrm{m}$ peak to peak amplitude. Phospholipid concentrations were determined by phosphate analysis (Böttcher et al., 1961).

Factor Va assay - Factor Va was quantitated by measuring its cofactor activity in factor Xa-catalyzed prothrombin activation at saturating concentrations of factor $\mathrm{Xa}$, phospholipid vesicles and prothrombin and at a limiting amount of factor Va (Tans et al., 1991). The factor Va concentration in the assay mixture was 
calculated from the rate of prothrombin activation using a turnover number of 6000 moles prothrombin activated per min per mole of factor XaVa complex (Tans et al., 1991).

It should be emphasized that the quantitation of the two forms of factor Va (factor $\mathrm{Va}_{1}$ and factor $\mathrm{Va}_{2}$ ) that are studied in this paper is correct despite the fact that there are reaction conditions at which they express different cofactor activities in prothrombin activation. This is inherent to the fact that the high concentrations of factor Xa, prothrombin and phospholipids used in the assay system nullify the differences in cofactor activities (see Results, Table 1)

Kinetic data analysis - Complex formation between membrane-bound factor $\mathrm{Xa}$ and factor $\mathrm{Va}$ was determined by measuring the rate of prothrombin activation in the presence of phospholipid vesicles at a fixed limiting concentration of factor Xa and varying amounts of factor $\mathrm{Va}$. Factor $\mathrm{Va}$, factor $\mathrm{Xa}$ and phospholipid vesicles were preincubated for 5 minutes at $37{ }^{\circ} \mathrm{C}$ in $25 \mathrm{mM}$ Hepes (pH 7.5), $175 \mathrm{mM} \mathrm{NaCl}$, $2 \mathrm{mM} \mathrm{CaCl}$ and $5 \mathrm{mg} / \mathrm{ml} \mathrm{BSA}$. Activation was started by addition of prothrombin (preincubated at $37^{\circ} \mathrm{C}$ in the same buffer). Rates of prothrombin activation were determined with the chromogenic substrate S2238 (Rosing et al., 1980). The apparent $K_{d}$ for dissociation of the membrane-bound factor XaVa complex $\left(K_{1 / 2 \mathrm{Va}}\right)$ and the prothrombin-converting activity of this complex at [factor $\mathrm{Va}] \rightarrow \infty\left(V_{\mathrm{Va}-\infty}\right)$ were obtained from a plot of the rate of prothrombin activation as function of the factor $\mathrm{Va}$ concentration that was fitted to the equation for a single site binding isotherm (hyperbola) in the computerprogram "Enzfitter".

The kinetic parameters of factor Xa-catalyzed prothrombin activation $\left(K_{\mathrm{m}}\right.$ for prothrombin and $V_{\max }$ of prothrombin activation) were determined by measuring the rate of thrombin formation at varying prothrombin concentrations in the presence of a fixed phospholipid concentration, a limiting amount of factor Xa and a saturating concentration factor $\mathrm{Va}$ under conditions described in the previous paragraph. The kinetic parameters were obtained by fitting the data to the Michaelis-Menten equation using the Enzfitter computer program.

Binding Studies - Binding parameters for factor Va-membrane association were determined on planar phospholipid bilayers. The concentrations of membranebound factor Va were determined by ellipsometry (Cuypers et al., 1983) and the free factor Va concentrations were determined with the functional assay described above. Amounts of phospholipid-bound factor Va were plotted as function of the free factor Va concentration and the binding parameters $\left(K_{\mathrm{d}}\right.$ and number of membrane binding sites) were obtained by fitting the data to the equation for a single site binding isotherm in the computerprogram "Enzfitter". 


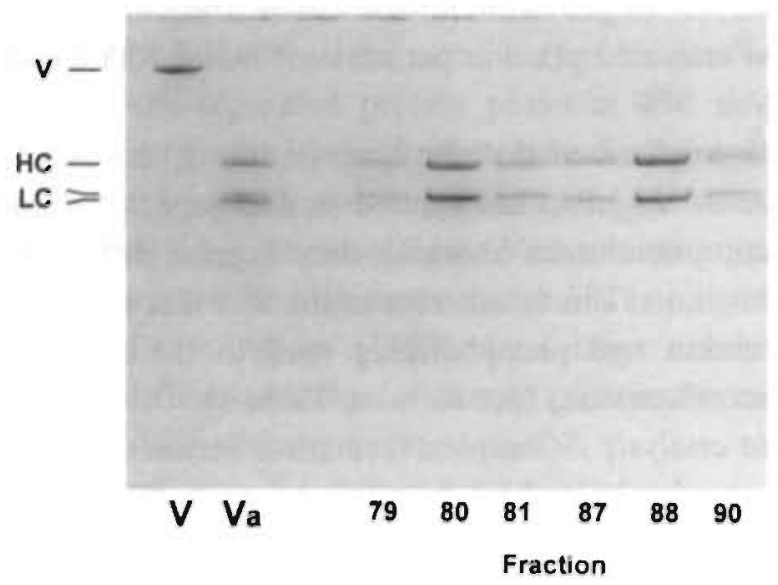

Figure 1. Gelelectrophoretic analysis of factor $\mathrm{V}$ and $\mathrm{Va}$ preparations. Factor $\mathrm{V}$, thrombin-activated factor $\mathrm{V}$, and factor $\mathrm{Va}_{1}$ and Factor $\mathrm{Va}_{2}$ that eluted from the mono-S column were subjected to SDSPAGE on slabgels containing $7.5 \%$ acrylamide (Schägger and von Jachow, 1987). $20 \mu \mathrm{l}$ of a factor $\mathrm{V}$ or Va-containing sample (0.6-5 $\mu$ g protein) was mixed with $5 \mu$ l electrophoresis sample buffer and applied to the gel. Lane 1, factor V; lane 2, thrombin-activated factor V (factor Va); fraction 79-81 = factor $\mathrm{Va}_{1}$; fraction $87-90=$ factor $\mathrm{Va}_{2}$. Gels were stained with Coomassie brilliant blue $\mathrm{R}-250$.

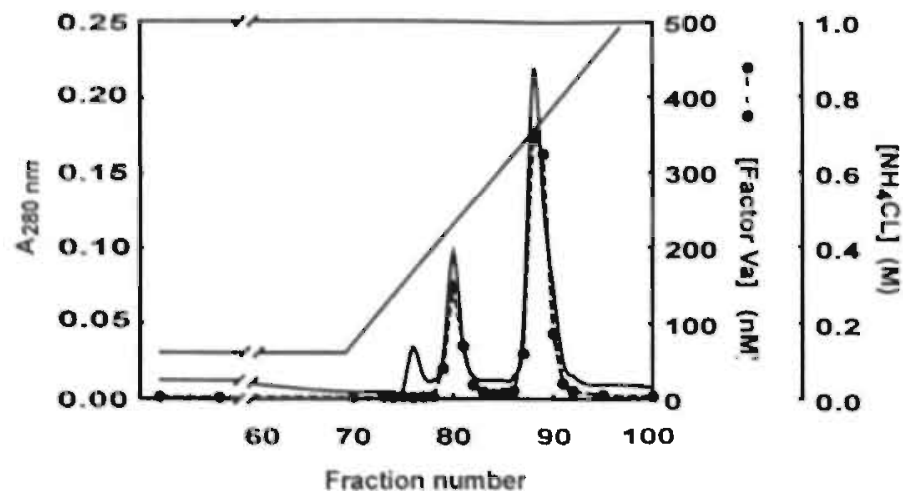

Figure 2. Chromatography of factor $\mathrm{Va}$ on mono-S. Factor Va obtained from prothrombin CL 4BSepharose was diluted to $0.6 \mathrm{mg} / 20 \mathrm{ml}$ in a buffer containing $25 \mathrm{mM} \mathrm{HEPES} \mathrm{pH} 7.5,50 \mathrm{mM} \mathrm{NH}_{4} \mathrm{Cl}$ and $5 \mathrm{mM} \mathrm{CaCl}_{2}$ and was applied to a mono-S column (HR 5/5) that was equilibrated with the same buffer. After application of factor $\mathrm{Va}$ the column was washed with $15 \mathrm{ml}$ buffer. Factor $\mathrm{Va}$ was subsequently eluted from the column with $15 \mathrm{ml}$ of a linear gradient ( 50 to $1000 \mathrm{mM} \mathrm{NH} 4 \mathrm{Cl}$ ) in 25 $\mathrm{mM}$ HEPES (pH 7.5), $5 \mathrm{mM} \mathrm{CaCl} 2$. Fractions $(0.5 \mathrm{ml})$ were collected and assayed for factor $\mathrm{Va}$ activity $(\bullet)$ as described under the EXPERIMENTAL PROCEDURES. Fractions from peak $1(79-81)$ and peak $2(87-90)$ were subjected to SDS-PAGE (figure 1). 


\section{RESULTS}

Separation of two forms of Factor Va by FPLC on a MonoS column Purified human factor $\mathrm{V}$ was converted into factor Va with thrombin. Factor Va was subsequently separated from the activation fragments by chromatography on a prothrombin-Sepharose column ( $c f$. Guinto and Esmon, 1984). SDSgelelectrophoretic analysis showed that this procedure yielded a pure factor $\mathrm{Va}$ preparation that consisted of a heavy chain with a MW of 105,000Da and the characteristic light chain doublet migrating in the 71,000-74,000 molecular weight region (Figure 1, lane 2).

Although anion exchangers are usually employed in the purification of factor $\mathrm{V}$ and $\mathrm{Va}$ it appears that the light chain of factor $\mathrm{Va}$ is a basic protein with a high affinity for cation exchangers (Lindhout et al., 1982; Odegaard and Mann, 1987). Figure 2 shows that factor $\mathrm{Va}$ also bound to a Mono-S column. Subsequent elution with a $\mathrm{NH}_{4} \mathrm{Cl}$ gradient yielded two protein peaks with factor Va activity. SDSPAGE analysis showed that the first peak consisted of factor Va molecules with a light chain of $\mathrm{MW}=74,000 \mathrm{Da}$ (Figure 1, fraction 79-81) and that the factor Va that eluted in the second peak contained the light chain with a $\mathrm{MW}=71,000 \mathrm{Da}$ (Figure 1 , fraction 87-90). In the text that follows we will designate the factor Va present in the first peak, factor $\mathrm{Va}_{1}$, while the factor $\mathrm{Va}$ present in the second peak will be called factor $\mathrm{Va}_{2}$.

Separation of Two Forms of Factor $V$ on a Mono-S Column - Non-activated human factor $\mathrm{V}$ showed a chromatographic behaviour that strongly resembled factor $\mathrm{Va}$. Factor $\mathrm{V}$ also bound to the Mono $\mathrm{S}$ column and eluted as a double peak when the column was developed with a $\mathrm{NH}_{4} \mathrm{Cl}$ gradient (Figure $3 \mathrm{~A}$ ). Incubation of the protein fractions with thrombin yielded two factor $\mathrm{Va}$ activity peaks which, as shown by SDS-PAGE analysis (Figure 3B), were highly enriched in the 74,000Da and $71,000 \mathrm{Da}$ light chains, respectively. This experiment indicates that the light chain doublet present on SDS gels of factor Va preparations does not result from additional peptide bond cleavages that occur during the activation of factor $\mathrm{V}$ by thrombin but shows that the heterogeneity in the light chain domain is already present in factor $\mathrm{V}$.

Structural Properties of Plasma and Platelet Factor V Present in Freshly Collected Blood Samples - The experiments presented in the previous paragraph strongly suggest that purified factor $\mathrm{V}$ preparations already contain two forms of 


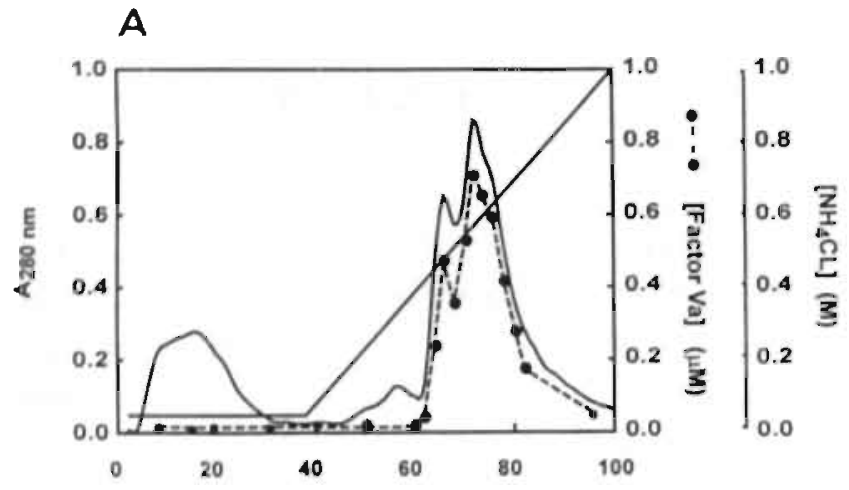

Fraction number

B

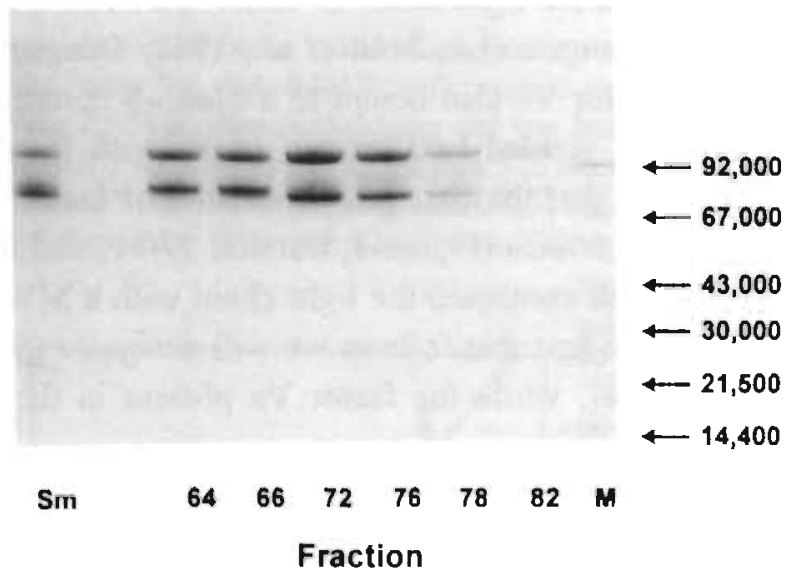

Figure 3. (A) Chromatography of factor $\mathrm{V}$ on monoS. $5 \mathrm{ml}$ of purified factor $\mathrm{V}(5 \mathrm{mg})$ in $10 \mathrm{mM}$ HEPES (pH 7.5), $50 \mathrm{mM} \mathrm{NaCl}$ was applied to a Mono $\mathrm{S}$ column (HR 5/5). The column was washed with $15 \mathrm{ml}$ of a buffer containing $25 \mathrm{mM}$ HEPES ( $\mathrm{pH} 7.5$ ), $50 \mathrm{mM} \mathrm{NH}_{4} \mathrm{Cl}$ and $5 \mathrm{mM} \mathrm{CaCl}_{2}$ and subsequently developed with $30 \mathrm{ml}$ of a linear gradient from 50 to $1000 \mathrm{mM} \mathrm{NH}_{4} \mathrm{Cl}$ in $25 \mathrm{mM}$ HEPES (pH 7.5) and $5 \mathrm{mM} \mathrm{CaCl} 2$. Samples from the column fractions were incubated for 1 hour at $37^{\circ} \mathrm{C}$ with thrombin (final concentration $25 \mathrm{nM}$ ) and the factor Va generated (•) was assayed as described under EXPERIMENTAL. PROCEDURES. (B) Gelelectrophoretic analysis of factor Va generated in the factor $\mathrm{V}$ fractions that eluted from the monoS column. Aliquots $(50 \mu \mathrm{l})$ from the column fractions $(64,66,72,76,78$, and 82$)$ were activated with thrombin (Figure 3A) and subsequently mixed wih $12.5 \mu \mathrm{l}$ gelelectrophoresis sample buffer (Schăgger and von Jachow, 1987). $20 \mu \mathrm{l}$ of the gelsamples were then applied to a $7.5 \%$ slabgel and subjected to SDS-PAGE (Schägger and von Jachow, 1987). Sm is a lane with starting material (factor V) activated with thrombin, MW is a lane with molecular weight markers. The proteins on the gel were stained with Coomassie brilliant blue $\mathrm{R} \cdot 250$. 
factor V. However, this does not necessarily mean that there are also two forms of factor $\mathrm{V}$ circulating in plasma, since it is possible that the heterogeneity of purified factor $\mathrm{V}$ preparations results from reactions that occurred during the purification procedure. In order to exclude this possibility we performed the following experiment. Freshly collected blood samples were subjected to two centrifugation steps which successively removed the erythrocytes and blood platelets and yielded platelet-poor plasma. The platelet pellet was resuspended in buffer and thrombin was added to both the platelet poor plasma and to the platelet suspension. The generation of factor $\mathrm{Va}$ activity was followed and after complete activation of factor $\mathrm{V}$ the plasma and platetet suspensions were diluted and applied to a MonoS column. Development of this column with a linear $\mathrm{NH}_{4} \mathrm{Cl}$ gradient yielded both for the plasma (Figure 4) and the platelet sample (data not shown) two factor Va activity peaks that eluted between $450-500 \mathrm{mM}$ and $700-750 \mathrm{mM} \mathrm{NH}_{4} \mathrm{Cl}$, respectively.

From the fact that the time interval between taking the blood samples and separating the plasma and platelet factor Va samples on the MonoS column was only $50 \mathrm{~min}$ and since the activity ratios of the two factor Va peaks in the plasma and platelet samples were approximately the same as those observed in purified factor $V(a)$ preparations (the purification of which took 4 days) we conclude that the heterogeneity of factor $\mathrm{V}$ does not result from reactions that have occurred during the purification procedure. The presence of two forms of factor $V$ in fresh plasma and platelet samples indicates that the heterogeneity is an intrinsic property of factor $\mathrm{V}{ }^{\star}$

Cofactor activities of the two forms of factor $\mathrm{Va}$ - Expression of the cofactor activity of factor $\mathrm{Va}$ is dependent on direct interactions with prothrombin, factor $\mathrm{Xa}$ and phospholipid. In the factor Va assay (see EXPERIMENTAL PROCEDURES) the reaction conditions are chosen such that factor $\mathrm{Va}$ is the limiting factor and all other components are present in excess. This means that under these conditions differences in protein-protein or protein-lipid interactions between the two forms of factor Va may nullify and escape attention.

\footnotetext{
* In the factor $\mathrm{Va}$ assay reaction conditions were such that factor $\mathrm{Va}$ was present at a limiting. concentration and all other components were added in excess. The phospholipid concentration and composition (100 $\mu \mathrm{M}$ PS/PC, 10/90, M/M) and the high factor Xa concentration ( $5 \mathrm{nM}$ ) ensures full incorporation of factor $\mathrm{Va}$ into the membrane-bound factor $\mathrm{XaVa}$ complex. Complete incorporation of both factor $\mathrm{Va}_{1}$ and factor $\mathrm{Va}_{2}$ into the prothrombinase complex is shown by the fact that rates of prothrombin activation were not further increased when the prothrombin, phospholipid and factor Xa concentrations in the assay mixture were increased. The validity of this assay for quantitating factor $\mathrm{Va}_{1}$ and $\mathrm{Va}_{2}$ preparations is also shown by the fact that preparations which were set at the same protein concentration on basis of $\mathrm{A}_{280}$ yielded the same concentrations in the functional assay.
} 


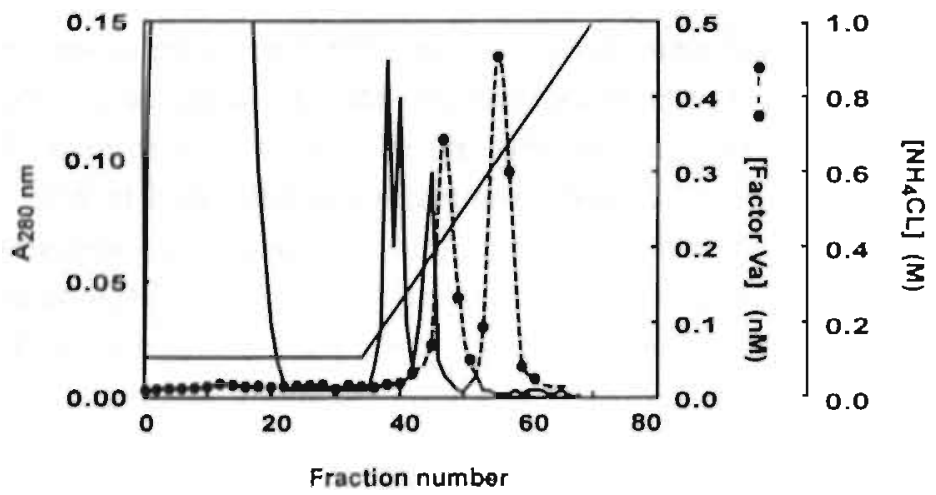

Figure 4. Cliromatography of thrombin-activated plasma on a monoS column. Platelet poor plasma derived from blood collected in eitric acid was brought at $5 \mathrm{mM}$ free $\mathrm{CaCl}_{2}$ and incubated for 10 min at $37^{\circ} \mathrm{C}$ with thrombin (final concentration $10 \mathrm{nM}$ ). The fibrin clot that was formed was removed and $1 \mathrm{ml}$ of the serum was diluted 5 times with column buffer $(25 \mathrm{mM}$ HEPES pH $7.5,5 \mathrm{mM} \mathrm{CaCl}$ ) and applied to a monoS column (HR 5/5). The column was washed with $13 \mathrm{ml}$ of a buffer containing $25 \mathrm{mM}$ HEPES (pH 7.5), $150 \mathrm{mM} \mathrm{NH}_{4} \mathrm{Cl}$, and $5 \mathrm{mM} \mathrm{CaCl}_{2}$ and the proteins bound to the column were subsequently eluted with $15 \mathrm{ml}$ of a salt gradient from 50 to $1000 \mathrm{mM} \mathrm{NH}_{4} \mathrm{Cl}$ in $25 \mathrm{mM}$ HEPES ( $\mathrm{pH} 7.5)$ and $5 \mathrm{mM} \mathrm{CaCl}$. Column fractions $(0.5 \mathrm{ml})$ were assayed for factor $\mathrm{Va}$ activity (•) as described under EXPERIMENTAL PROCEDURES.
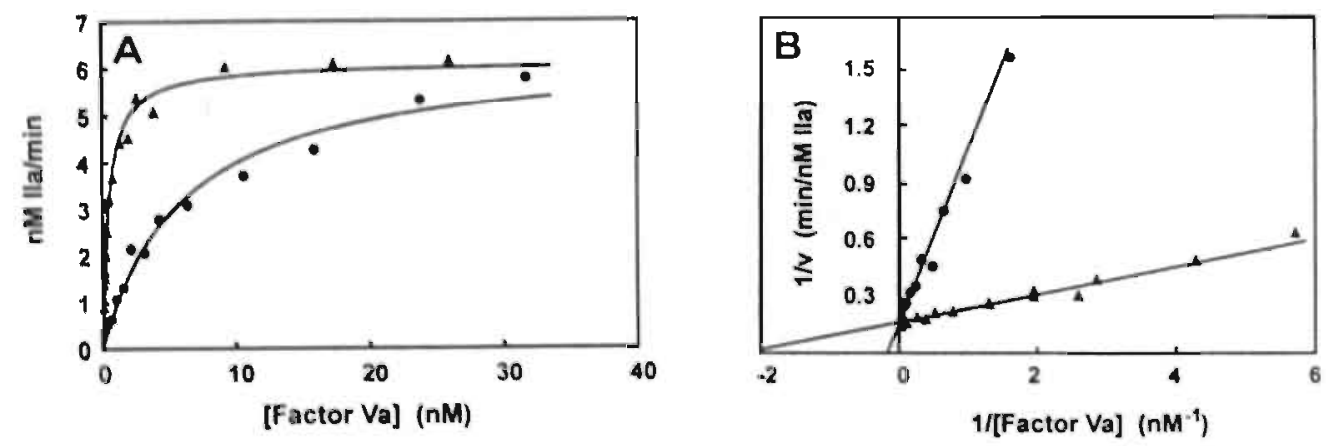

Figure 5. Comparison of cofactor activities of factor $\mathrm{Va}_{1}$ and factor $\mathrm{Va}_{2}$. Rates of prothrombin activation at limiting factor $\mathrm{Xa}$ were determined in at reaction mixture containing $25 \mathrm{mM}$ Hepes $(\mathrm{pH}$ 7.5), $175 \mathrm{mM} \mathrm{NaCl}, 2 \mathrm{mM} \mathrm{CaCl}, 5 \mathrm{mg} / \mathrm{ml} \mathrm{BSA}, 2$ MM phospholipid vesicles (DOPS/DOPC, 5/95, $\mathrm{M} / \mathrm{M}$ ), $3 \mathrm{pM}$ factor $\mathrm{Xa}, 1 \mu \mathrm{M}$ prothrombin and amounts of factor $\mathrm{Va}_{1}$ (o) or factor $\mathrm{Va}_{2}$ ( $\mathbf{( \Delta )}$ indicated in the figure. Further experimental conditions are described under EXPERIMENTAL. PROCEDURES. (A) Rate of prothrombin activation as function of the concentration factor $\mathrm{Va}_{1}$ or factor $\mathrm{Va}_{2}$. The solid lines represent hyperbola obtained after fitting the data with $K_{1 / 2} \mathrm{Va}_{1}=5.93 \mathrm{nM}$ and $V_{\mathrm{Va} \rightarrow \infty}=5.35 \mathrm{nM} \mathrm{Ila} / \min (\bullet)$ or $K_{1 / 2 \mathrm{~V}_{2}}=0.45 \mathrm{nM}$ and $V_{\mathrm{Va} \rightarrow \infty}=5.15 \mathrm{nM} \mathrm{IIa/min}(\mathbf{A})$. (B) Double reciprocal plots of the same data. 
To compare the cofactor activities of the two forms of factor Va we have, therefore, performed a kinetic analysis of the stimulatory effects of the factor Va preparations on prothrombin activation under suboptimal reaction conditions i.e. at a limiting amount of factor $\mathrm{Xa}$ and at a low concentration of phospholipid vesicles containing a low mole percentage PS $(2 \mu \mathrm{M}$ DOPS/DOPC, $5 / 95, \mathrm{M} / \mathrm{M})$. Figure 5 shows that there was a rather large difference between the amounts of factor $\mathrm{Va}_{1}$ and factor $\mathrm{Va}_{2}$ required for the assembly of a functionally active membrane-bound factor $\mathrm{XaVa}$ complex. Half maximal prothrombinase complex formation was observed at $5.93 \mathrm{nM}$ factor $\mathrm{Va}_{1}$ and $0.45 \mathrm{nM}$ factor $\mathrm{Va}_{2}$, respectively. A double reciprocal plot of these data (Figure 5B) shows that the rates of prothrombin activation attained at saturating levels of factor Va were approximately the same (Table 1), which indicates that the factor $\mathrm{XaVa}_{1}$ and $\mathrm{XaVa}_{2}$ complexes, once they are formed, have equal catalytic activities.

The differences in factor XaVa complex formation dissappeared when the same experiment was performed with phospholipid vesicles that contained a high mole percentage PS (i.e. $2 \mu \mathrm{M}$ PS/PC, $20 / 80 \mathrm{M} / \mathrm{M}$ ). On these membranes half maximal prothrombinase complex formation required $0.047 \mathrm{nM}$ factor $\mathrm{Va}_{1}$ and $0.044 \mathrm{nM}$ factor $\mathrm{Va}_{2}$, respectively (Table 1). This experiment indicates that the different efficiencies by which factors $V_{a_{1}}$ and $V_{a_{2}}$ incorporate in the

Table 1. Kinetic analysis of the functional activities of Factor $\mathrm{Va}_{1}$ and $\mathrm{Va}_{2}$. Cofactor activities of factor $\mathrm{Va}_{\mathrm{J}}$ and factor $\mathrm{Va}_{2}$ were determined by measuring rates of prothrombin activation at a limiting factor $\mathrm{Xa}$ concentration in a reaction mixture containing $25 \mathrm{mM}$ Hepes (pH 7.5), $175 \mathrm{mM} \mathrm{NaCl}, 2$ $\mathrm{mM} \mathrm{CaCl} 2,5 \mathrm{mg} / \mathrm{ml}$ BSA, $3 \mathrm{pM}$ factor Xa, $1 \mu \mathrm{M}$ prothrombin, varying amounts of factor $\mathrm{Var}_{1}$ or factor $\mathrm{Va}_{2}$ and phospholipid vesicles as indicated in the Table. Rates of prothrombin activation were plotted against the factor $\mathrm{Va}$ concentrations and $K_{1 / 2} \mathrm{Va}_{\mathrm{a}}$ and $V_{\mathrm{Va} \rightarrow \infty}$ were obtained by fitting the data. to a hyperbola (see Figure 5). Further experimental conditions are given under EXPERIMENTAL. PROCEDURES.

\begin{tabular}{llclc}
\hline & \multicolumn{2}{c}{ Factor $\mathrm{Va}_{1}$} & \multicolumn{2}{c}{ Factor $\mathrm{Va}_{2}$} \\
\cline { 2 - 5 } Phospholipid & $\begin{array}{c}K_{1 / 2 \mathrm{Va}_{1}} \\
(\mathrm{nM})\end{array}$ & $\begin{array}{c}V_{\mathrm{Va}_{\mathrm{a}} \rightarrow \infty} \\
(\mathrm{nM} \mathrm{IIa/min})\end{array}$ & $\begin{array}{c}K_{1 / 2 \mathrm{Va}_{2}} \\
(\mathrm{nM})\end{array}$ & $\begin{array}{c}V_{\mathrm{Va} \rightarrow \infty} \\
(\mathrm{nM} \mathrm{IIa/min})\end{array}$ \\
\hline $2 \mu \mathrm{M}$ PS/PC (5/95) & 5.93 & 5.35 & 0.45 & 5.15 \\
$2 \mu \mathrm{M}$ PS/PC $(20 / 80)$ & 0.047 & 18.6 & 0.044 & 17.9 \\
$0.1 \mu \mathrm{M}$ PS/PC (20/80) & 0.39 & 12.8 & 0.044 & 13.5 \\
\hline
\end{tabular}


Table 2. Kinetic parameters of prothrombin activation. Rates of prothrombin activation at a limiting factor Xa concentration were determined in a reaction mixture containing $25 \mathrm{mM}$ Hepes (pH 7.5), $175 \mathrm{mM} \mathrm{NaCl}, 2 \mathrm{mM} \mathrm{CaCl} 2,5 \mathrm{mg} / \mathrm{ml} \mathrm{BSA}, 10 \mu \mathrm{M}$ phospholipid vesicles (DOPS/DOPC, 5/95, $\mathrm{M} / \mathrm{M}), 3 \mathrm{pM}$ factor $\mathrm{Xa}, 25 \mathrm{nM}$ factor $\mathrm{Va}_{1}$ or factor $\mathrm{Va}_{2}$ and varying amounts of prothrombin. Kinetic parameters $\left(K_{\mathrm{m}}\right.$ and $V_{\max }$ ) were obtained by fitting the data to the Michaelis-Menten equation using the Enzfitter computer program. Further experimental conditions are given under EXPERIMENTAL PROCEDURES.

\begin{tabular}{lcc}
\hline & $\begin{array}{c}K_{\mathrm{m}} \\
(\mu \mathrm{M})\end{array}$ & $\begin{array}{c}V_{\max } \\
(\mathrm{mol} / \mathrm{min} / \mathrm{mol} \mathrm{Xa})\end{array}$ \\
\hline Factor $\mathrm{Va}_{1}$ & 0.32 & 5386 \\
Factor $\mathrm{Va}_{2}$ & 0.16 & 5687 \\
\hline
\end{tabular}

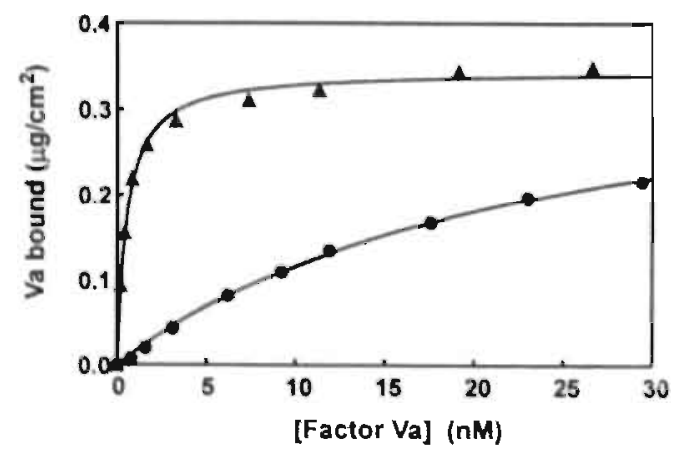

Figure 6. Binding of factor $\mathrm{Va}_{1}$ and $\mathrm{Va}_{2}$ to planar phospholipid bilayers. Binding of factor $\mathrm{Va}_{1}$ (e) and factor $\mathrm{Va}_{2}(\mathbf{A})$ to planar phospholipid bilayers (DOPS/DOPC, 20/80, M/M) was determined by ellipsometry (Cuypers et al., 19883) in a reaction mixture containing $25 \mathrm{mM}$ Hepes (pH 7.5), 150 $\mathrm{mM} \mathrm{NH}_{4} \mathrm{Cl}, 5 \mathrm{mM} \mathrm{CaCl}$ and $5 \mathrm{mg} / \mathrm{ml} \mathrm{BSA}$. The solid lines represent hyperbolas obtained after fitting the data with $\mathrm{K}_{\mathrm{d} \mathrm{Va}_{1}}=24 \mathrm{nM}$ and $0.397 \mu \mathrm{g}$ factor $\mathrm{Va}_{2}$ bound $/ \mathrm{cm}^{2}$ phospholipid at saturating factor $\mathrm{Va}_{1}$ or $\mathrm{K}_{\mathrm{d} \mathrm{Va}_{2}}=0.53 \mathrm{nM}$ and $0.364 \mu \mathrm{g}$. factor $\mathrm{Va}_{2}$ bound $/ \mathrm{cm}^{2}$ phospholipid at an infinite concentration of factor $\mathrm{Va}_{2}$. 
prothrombinase complex are likely compensated by an increased binding affinity and an increased number of binding sites for factor $\mathrm{Xa}$ and $\mathrm{Va}$ on membranes containing 20 mole \% PS (Lindhout et al., 1982; van de Waart et al., 1983; Nelsestuen and Broderius, 1977; Bloom et al., Pusey et al., 1982; Krishnaswamy and Mann, 1988). This argumentation predicts that differences between factors $\mathrm{Va}_{1}$ and $\mathrm{Va}_{2}$ can also be observed on membranes with $20 \mathrm{~mole} \% \mathrm{PS}$, provided that the experiment is performed at a lower phospholipid concentration. Indeed titration of a limited amount of factor Xa with factor $\mathrm{Va}_{1}$ or factor $\mathrm{Va}_{2}$ on $0.1 \mathrm{uM}$ PS/PC $(20 / 80, \mathrm{M} / \mathrm{M})$ vesicles again showed a difference between the two forms of factor Va (Table 1). At this phospholipid concentration a 9-fold higher concentration of factor $\mathrm{Va}_{1}$ was required to obtain half maximal rates of prothrombin activation $(0.389 \mathrm{nM}$ factor $\mathrm{Va}_{1}$ versus $0.044 \mathrm{nM}$ factor $\mathrm{Va}_{2}$ ).

With respect to the different functional properties of factors $\mathrm{Va}_{1}$ and $\mathrm{Va}_{2}$ the possibility has to be ruled out that factor $\mathrm{Va}_{4}$ lacks functional activity and that the cofactor activity of factor $V \mathrm{~V}_{1}$ is due to a small $(\sim 8 \%)$ contamination with factor $\mathrm{Va}_{2}$. This possibility is excluded by the observations that a) the amounts of factor $\mathrm{Va}_{1}$ and factor $\mathrm{Va}_{2}$ required for factor $\mathrm{XaVa}$ complex formation on $2 \mu \mathrm{M}$ PS/PC (20/80) were the same (Table 1) and b) that equal protein amounts or factor $\mathrm{Va}_{1}$ or factor $\mathrm{Va}_{2}$ yield the same concentrations in the quantitative functional assay (Rosing et al., 1980).

Table 2 summarizes the kinetic parameters for prothrombin activation determined at saturating concentrations of factor $\mathrm{Va}_{1}$ or factor $\mathrm{Va}_{2}$. Similar values were obtained for the $K_{\mathrm{m}}$ for prothrombin and the $V_{\max }$ of prothrombin activation for both forms of factor $\mathrm{Va}$. This indicates that factor $\mathrm{Va}_{1}$ and $\mathrm{Va}_{2}$ neither differ in their interaction with prothrombin nor in their capacity to promote the catalytic activity of factor Xa, but exhibit considerable differences in their ability to assemble into a membrane-bound factor XaVa complex.

Membrane Binding Properties of Factor $\mathrm{Va}_{1}$ and Factor $\mathrm{Va}_{2}$ - The impaired incorporation of factor $\mathrm{Va}_{1}$ into the membrane-bound factor $\mathrm{XaVa}$ complex most likely results from a decreased affinity for either phospholipid or factor $\mathrm{Xa}$. To distinguish between these possibilities we have determined the affinity of both forms of factor Va for

PS-containing membranes (Figure 6). Factor $\mathrm{Va}_{2}$ bound with high affinity to membranes composed of $20 \mathrm{~mole} \%$ PS in PC. A hyperbolic fit of the binding data yielded a $K_{\mathrm{d}}$ of $0.53 \mathrm{nM}$ and $0.364 \mu \mathrm{g}$ factor $\mathrm{Va}_{2}$ bound $/ \mathrm{cm}^{2}$ phospholipid at saturating factor $\mathrm{Va}$. Factor $\mathrm{Va}_{1}$ had a much lower affinity for phospholipid and with 
the amounts of factor $\mathrm{Va}_{1}$ available we were unable to add sufficiently high concentrations to achieve saturation of the membrane surface (Figure 6). From a hyperbolic fit of the binding curve it can be estimated, however, that the interaction between factor $\mathrm{Va}_{1}$ and the membrane is characterized by a $K_{\mathrm{d}}$ of about $24 \mathrm{nM}$ and $0.397 \mu \mathrm{g}$ factor $\mathrm{Va}_{2}$ bound $/ \mathrm{cm}^{2}$ phospholipid at saturating factor $\mathrm{Va}_{1}$. From the molecular weights of factor $\mathrm{Va}(\sim 180,000)$ and the phospholipid used $(\sim 800)$ and considering that $1 \mathrm{~cm}^{2}$ of a bilayer phospholipid surface contains $0.4 \mu \mathrm{g}$ phospholipid it can be calculated that phospholipid to factor $\mathrm{Va}$ ratios at saturation are 227 and 247 for factor $\mathrm{Va}_{1}$ and factor $\mathrm{Va}_{2}$, respectively.

These observations show that the two forms of factor Va differ considerably in their affinity for phospholipids while the number of binding sites for factor $\mathrm{Va}_{1}$ and factor $\mathrm{Va}_{2}$ on the phospholipid surface are the same. The large affinity difference very likely explains the different cofactor activities of factor $\mathrm{Va}_{1}$ and afertor $\mathrm{N}_{2}$ - ir porthermbinastivation 


\section{DISCUSSION}

Purified human factor Va preparations have been reported to consist of a heavy chain with a $\mathrm{MW}$ of $\approx 105,000 \mathrm{Da}$ and a doublet light chain with $\mathrm{MWs}$ of $\approx$ $71,000 \mathrm{Da}$ and $\mathrm{MW} \approx 74,000 \mathrm{Da}$, respectively (Suzuki et al., 1982). The data presented in this paper show that it is possible to bind factor Va to a MonoS column and to separate two forms of factor $\mathrm{Va}$ by developing the column with a $\mathrm{NH}_{4} \mathrm{Cl}$ gradient. The peak eluting at the low salt concentration consisted of factor $\mathrm{Va}\left(\mathrm{Va}_{1}\right)$ with the $\approx 74,000 \mathrm{Da}$ light chain, whereas factor Va with $\mathrm{a} \approx 71,000 \mathrm{Da}$ light chain (factor $\mathrm{Va}_{2}$ ) eluted at a much higher salt concentration. It is likely that the factor $\mathrm{Va}$ bound to the MonoS column via its light chain since this subunit is considered to be a basic protein which exhibits a high affinity for cation exchangers (Lindhout et al,, 1982; Odegaard and Mann, 1987). The elution profile from the MonoS column is, therefore, indicative for a charge difference between the light chains of factors $\mathrm{Va}_{1}$ and $\mathrm{Va}_{2}$, in the sense that the light chain of factor $\mathrm{Va}_{2}$ is more positively charged than the light chain of factor $V a_{1}$.

The interaction of factor Va with procoagulant membranes appears to depend on both hydrophobic interactions (Higgins and Mann, 1983; Lecompte et al., 1987; Krieg et al., 1987; Kalafatis et al., 1990) and on electrostatic interactions between the positively charged light chain and negatively charged phospholipids (Pusey et al., 1982; van de Waart et al., 1983; Pusey and Nelsestuen, 1984). Considering that electrostatic interactions are important for factor Va-membrane association and that there might be a considerable charge difference between the light chains of the two factors $\mathrm{Va}$ forms, we hypothesized that factor $\mathrm{Va}{ }_{1}$ may exhibit a lower affinity for negatively charged membranes than factor $\mathrm{Va}_{2}$. Direct binding experiments show that this is indeed the case. Factor $\mathrm{Va}_{2}$ binds with a high affinity $\left(K_{\mathrm{d}}=0.53 \mathrm{nM}\right)$ to PS-containing membranes (PS/PC, 20/80), whereas the affinity of factor $\mathrm{Va}_{1}$ for such membranes is much less $\left(K_{\mathrm{d}} \approx 24 \mathrm{nM}\right)$. The lipid/factor Va ratios $(\mathrm{n})$ at protein saturation were approximately the same $\left(n=227\right.$ for factor $V a_{1}$ and $n=247$ for factor $\mathrm{Va}_{2}$ ) which shows that the membrane surface contains the same number of binding sites for both forms of factor $\mathrm{Va}$. It is difficult to compare the binding parameters with literature values since the interaction of human factor $\mathrm{Va}$ with membranes is not well documented whereas a wide range of binding parameters $\left(K_{\mathrm{d}}=0.05-10 \mathrm{nM}\right.$ and $n=42-250$ ) is reported to describe the interaction of bovine factor Va with PC membranes that contain 25 mole \% PS (Bloom et al., 1979; Pusey et al., 1982; van 
de Waart et al., 1983; Pusey and Nelsestuen, 1984; Krishnaswamy and Mann, 1988).

Factor Va plays an important role in both the assembly and expression of the catalytic activity of the prothrombinase complex on procoagulant membrane surfaces (Nesheim et al., 1979; Rosing et al., 1980; Lindhout et al., 1982; van Rijn et al., 1984). Since proper cofactor function requires the binding of factor $V a$ to the membrane it is to be expected that the different affinities of factors $\mathrm{Va}_{1}$ and $\mathrm{Va}_{2}$ for negatively charged membranes will result in different efficiencies to act as a cofactor in prothrombin activation. Kinetic experiments showed that the cofactor function of factor $\mathrm{Va}_{1}$ is indeed impaired. Much higher amounts of factor $\mathrm{Va}_{1}$ were required for full assembly of the prothrombinase (factor $\mathrm{XaVa}$ ) complex at the membrane surface. Once formed, the factor $\mathrm{XaVa}_{1}$ and $\mathrm{XaVa}_{2}$ complexes exhibit the same catalytic activity in prothrombin activation. This can be inferred from the fact that the kinetic parameters $\left(k_{\mathrm{cat}}\right.$ and $\left.K_{\mathrm{m}}\right)$ for prothrombin activation are similar (Table 2). Differences in efficiencies by which factor $\mathrm{Va}_{1}$ and $\mathrm{Va}_{2}$ assemble into a membranebound factor $\mathrm{XaVa}$ complex were only observed on membranes that contain low amounts PS or when prothrombin is activated at low phospholipid concentrations. This is not surprising if one considers that factor XaVa complex formation on the phospholipid surface is a reflection of the concentrations of surface-bound factor $\mathrm{Va}$ and factor Xa (Lindhout et al., 1982; Krishnaswamy et al., 1988). At high mole percentages PS and at high phospholipid concentrations differences between factor $\mathrm{Va}_{1}$ and $\mathrm{Va}_{2}$ will be nullified when the concentration of factor $\mathrm{Va}$ binding sites exceeds the $K_{\mathrm{d}}$ 's for the membrane-factor Va complexes since this condition results in virtually complete binding of both forms of factor $\mathrm{Va}$.

The heterogeneity in the light chains of factor $\mathrm{Va}$ is not a unique property of factor Va but is already present in factor V. It appears that the purified factor $\mathrm{V}$ preparations and even freshly prepared plasma samples and platelet suspensions contain two forms of factor $\mathrm{V}$ which after activation with thrombin are converted into factor $\mathrm{Va}_{1}$ and $\mathrm{Va}_{2}$, respectively. This shows that the heterogeneity is an intrinsic property of factor $\mathrm{V}$ and is not caused by reactions occurring during the purification procedure or to additional peptide bond cleavages that take place when factor $V$ is activated with thrombin.

Our experiments give no direct insight in the structural basis underlying the difference between the light chain regions of the two forms of factor V. However, combination of information presented in this paper with data recently reported by Ortel et al. (1992) strongly suggest that the observed heterogeneity originates from 
the carboxyl-terminal $\mathrm{C} 2$ domain of the light chain region of factor V. Ortel et al. (1992) isolated recombinant human factor $\mathrm{V}$ and showed that activation with thrombin resulted in the formation of a light chain doublet. Activation of mutant molecules that lack the carboxyl-terminal C2 domain (ie. amino acid residues 2037 2196) yield a factor Va molecule with a single truncated light chain with a MW of $\approx$ $62,000 \mathrm{Da}$. Deletion of the $\mathrm{C} 2$ domain caused an essentially complete loss of the ability of the mutant factor Va molecule to bind to negatively charged membranes. This indicates that the occurrence of two forms of factor $\mathrm{Va}\left(\mathrm{Va}_{\mathrm{i}}\right.$ and $\left.\mathrm{Va}_{2}\right)$ with different affinities for procoagulant membranes results from the presence of two light chains with structural differences in the $\mathrm{C} 2$ domain. The fact that heterogeneity is also observed in the factor $\mathrm{V}$ present in freshly prepared platelet and plasma samples and in recombinant factor V (Ortel et al., 1992) strongly suggests that the heterogeneity is due to differences in post-ribosomal processing or post-ribosomal modification (e.g. glycosylation) of the two factor $\mathrm{V}$ molecules. Whether the presence of two forms of factor $\mathrm{V}$ in plasma has a physiological function remains to be clarified.

\section{ACKNOWLEDGEMENTS}

We thank Rita Janssen and Dr. George Willems for performing the binding experiments on the ellipsometer. This work was supported by Program Grant 900526-192 from the Dutch Organisation for Scientific Research (NWO). 



\section{Chapter 7}

\section{SUMMARY and CONCLUDING REMARKS}

The purpose of the work described in this thesis was to gain more insight in some of the mechanisms of which thrombin formation is controlled during haemostasis, in particular with respect to the plasma proteins factor V (Va), activated protein $\mathrm{C}$ and protein $\mathrm{S}$. The first chapter gives an overview of the blood coagulation mechanism and to the literature pertinent to the current hypothesis concerning the mode of action of these proteins in the regulation of prothrombin activation. Purification of factor $\mathrm{V}$ from human plasma is described in Chapter 2. Factor $\mathrm{V}$ circulates in plasma in a concentration of approximately $8 \mu \mathrm{g} / \mathrm{ml}(\sim 25$ $\mathrm{nM}$ ). Due to the lability of factor $V$ complete inhibition of proteases during the isolation procedure is essential. The factor $\mathrm{V}$ purification method is in part based on the procedure developed by Dahlbăck (1980) and Suzuki et al. (1982). Modifications we made to this procedure resulted in decrease of the isolation time, higher yield, higher concentration of factor $\mathrm{V}$ and less contamination in the final preparation. Gel filtration (AcA-34 in the original procedures) is now performed with a Superdex-200 column coupled to a Pharmacia FPLC system. We also included a final ionexchange chromatography step using a MonoS column with the FPLC system to remove final remaining contaminations. This considerably improved our factor $\mathrm{V}$ isolation in terms of speed, quantity, and quality compared to the preparations chromatographed on low pressure gel filtration materials. Using this procedure, factor $V$ was purified from plasma more than 4000 -fold with a yield of $20 \%$ in 55 hours.

Protein C, when activated, is an important regulator of factor Va (see Chapter 4) and VIIIa activity. Activation of protein $C$ by non-physiological activators is of special interest since such activators can be used as tools in studies on the structurefunction relationship of protein $\mathrm{C}$, in the preparation of $\mathrm{APC}$ from protein $\mathrm{C}$, and in the development of functional protein $\mathrm{C}$ assays. Current quantitative protein $\mathrm{C}$ assay methods use a protein $\mathrm{C}$ activator isolated from the venom of Agkistrodon contortrix contoritix. This reaction is strongly inhibited by calcium ions and (at least in the case of human protein $\mathrm{C}$ ) by $\mathrm{NaCl}$. This phenomenon is of special importance for the use of this activator in a quantitative protein $\mathrm{C}$ assay, which, because of this sensitivity, requires well-controlled ionic strength and free $\mathrm{CaCl}_{2}$ concentration. 
Chapter 3 describes the purification and characterization of a protein $\mathrm{C}$ activator from the venom of Agkistrodon halys halys. The protein $\mathrm{C}$ activator from Agkistrodon halys halys venom was purified 533-fold by ion-exchange chromatography on QAE-Sephadex A-50, affinity chromatography on aprotininSepharose and MonoQ fast protein liquid chromatography (FPLC). The purified enzyme is a single chain protein with an apparent molecular weight of 36,000 . Activation of human protein $\mathrm{C}$ results from a specific cleavage in the heavy chain of the molecule. In the case of protein $C$ activation by its physiological activator, thrombin, this cleavage has been identified to result in the removal of a dodecapeptide of 1,400Da from the amino-terminus of the heavy chain (Kisiel, 1979). The protein $C$ activator purified from Agkistrodon halys halys very likely activates human protein $C$ via the same pathway. The protein $C$ activator exhibits a high amidolytic activity towards the chromogenic substrates S2302 and S2238. The activity of the activator is not affected by thiolprotease or metalloprotease inhibitors. Considerable inhibition, however, is observed when the protein $\mathrm{C}$ activator is incubated with the serine protease inhibitors benzamidin and soybean trypsin inhibitor, and virtually complete inhibition with the active site titrant pNPGB and inhibitor PPACK. This indicates that the protein $\mathrm{C}$ activator from Agkistrodon halys halys contains an active site serine and histidine which classifies the enzyme as a serine protease. The purified protease can activate both human and bovine protein $\mathrm{C}$. Activation of human protein $\mathrm{C}$ only occurs at an appreciable rate in a calcium-free reaction medium at low ionic strength. $\mathrm{Ca}^{2+}$ ions inhibited the activation of human protein $\mathrm{C}$ with an apparent $K_{\mathrm{i}}$ of $0.8 \mathrm{mM}$. Sodium chloride also strongly inhibits human protein $\mathrm{C}$ activation (with a $K_{\mathrm{i}}$ app of $20 \mathrm{mM} \mathrm{NaCl}$ ). In contrast, activation of bovine protein $\mathrm{C}$ is hardly affected by variation of $\mathrm{Ca}^{2+}$ and $\mathrm{NaCl}$ concentrations in the reaction medium. The apparent $K_{\mathrm{i}}^{\prime}$ s for calcium ion and $\mathrm{NaCl}$ inhibition of bovine protein $\mathrm{C}$ activation are $>10 \mathrm{mM}$ and $220 \mathrm{mM}$, respectively. Kinetic analysis of human protein $\mathrm{C}$ activation by the venom activator (in a calcium-free medium and at low ionic strength, $\mathrm{I}=0.05$ ) revealed an apparent $K_{\mathrm{m}}$ for protein $\mathrm{C}$ of $0.52 \mu \mathrm{M}$ and a $k_{\text {cat }}$ of $0.17 \mathrm{~s}^{-1}$. The catalytic efficiency $\left(k_{\text {cal }} / K_{\mathrm{m}}\right)$ observed is $3.3 * 10^{5} \mathrm{M}^{-1} \mathrm{~s}^{-1}$. At higher ionic strength $(\mathbb{I}=0.15)$ rates of human protein $C$ activation become linear with protein $\mathrm{C}$, indicating a strong increase in $K_{\mathrm{m}}$ with increasing ionic strength. Bovine protein $\mathrm{C}$ is activated (in the absence of $\mathrm{Ca}^{2+}$ ions and at $\mathrm{I}=0.1$ ) with a $K_{\mathrm{m}}$ of $0.056 \mu \mathrm{M}$ and a $k_{\text {cat }}$ of $0.24 \mathrm{~s}^{-1}$. The catalytic efficiency of bovine protein $\mathrm{C}$ activation $\left(k_{\mathrm{cat}} / K_{\mathrm{m}}=4.3 * 10^{6} \mathrm{M}^{-1} \mathrm{~s}^{-1}\right)$ is 13 -fold higher than of human protein $\mathrm{C}$ activation $\left(3.3 * 10^{5} \mathrm{M}^{-1} \mathrm{~s}^{-1}\right)$. This is caused by a lower $K_{\mathrm{m}}$ of the venom activator for 
bovine protein $\mathrm{C}$. These data are indicative for a rather large conformational and/or structural difference between human and bovine protein $\mathrm{C}$ at physiological ionic strength. In addition it seems likely that, in contrast to bovine protein $\mathrm{C}$, the conformation of human protein $\mathrm{C}$ changes considerable with changing ionic strength. Protein $\mathrm{C}$ activation by thrombin is also inhibited by calcium-ions but when thrombomodulin is present this reaction requires the presence of $\mathrm{Ca}^{2+}$.

Factor Va cofactor activity in vivo is down regulated by activated protein $\mathrm{C}$ in concert with protein $\mathrm{S}$. In Chapter 4 , we have analyzed the effects of $\mathrm{Ca}^{2+}$ ions, phospholipids and protein S on the kinetic parameters of APC-catalyzed factor Va inactivation using purified human proteins. In agreement with earlier reports, we observed that factor $\mathrm{Va}$ inactivation by APC is not strictly dependent on the presence of phospholipids and protein $\mathrm{S}$. The reaction in free solution requires the presence of $\mathrm{Ca}^{2+}$ ions, and at the optimal $\mathrm{Ca}^{2+}$ ion concentration $(2 \mathrm{mM})$, the reaction proceeds with a second order rate constant of $6.1 \times 10^{5} \mathrm{M}^{-1} \mathrm{~s}^{-1}$. The inactivation reaction in free solution has a high $K_{\mathrm{m}}$ for factor Va $(>78 \mathrm{nM})$. APCcatalyzed factor $\mathrm{Va}$ inactivation is greatly accelerated by negatively charged phospholipid vesicles. The extend to which phospholipids stimulate the reaction is dependent on the phospholipid concentration and composition. Optimal rates of factor $\mathrm{Va}$ inactivation are obtained in the presence of $10 \mu \mathrm{M}$ phospholipid vesicles with high mole percentage anionic phospholipid (DOPS/DOPC; 20/80; M/M). Under these reaction conditions $\mathrm{APC}$-catalyzed factor $\mathrm{Va}$ inactivation was characterized by an apparent second order rate constant of $1.4 \times 10^{8} \mathrm{M}^{-1} \mathrm{~s}^{-1}$. This is 230 -fold higher than the rate constant in free solution. The stimulatory effect of phospholipids on APC-catalyzed factor Va inactivation exhibits a clear optimum both with respect to the phospholipid concentration and DOPS/DOPC composition. Membranes that are solely composed of the neutral phospholipid phosphatidylcholine are not able to accelerate APC-catalyzed factor Va inactivation. Thus, in order to stimulate factor $\mathrm{Va}$ inactivation, membranes have to contain anionic phospholipids. The ability to stimulate factor $\mathrm{Va}$ inactivation is not strictly confined to phosphatidylserinecontaining membranes since membranes with other anionic phospholipids considerably enhance factor Va inactivation as well. The ability of different anionic phospholipids to enhance factor $\mathrm{Va}$ inactivation increased in the order phosphatidylethanolamine < oleic acid < phosphatidic acid < phosphatidylglycerol < phosphatidylmethanol < phosphatidylserine. Acceleration of APC-catalyzed factor 
$\mathrm{Va}$ inactivation by negatively charged membranes is presumably a reflection of the fact that both APC and factor Va bind to such membranes. This allows the inactivation of membrane-bound factor Va by membrane-bound APC. The apparent $K_{\mathrm{m}}$ for factor $\mathrm{Va}$ is greatly decreased in the presence of phospholipid membranes and appears to be a function of the phospholipid concentration present in the reaction medium. When the concentration of phospholipid is increased there is a parallel increase of the $K_{\mathrm{m}}$. Also the $V_{\max }$ of APC-catalyzed inactivation of factor $\mathrm{Va}$ appears to be a function of the phospholipid concentration. The $V_{\max }$ increases with the amount of phospholipid present and reaches a plateau at $10 \mu \mathrm{M}$ phospholipid. This strongly suggests that, in the presence of phospholipid, surfacebound factor $\mathrm{Va}$ is inactivated by surface-bound APC. In addition, the experiments presented in Chapter 4 indicate clearly that the promotion by protein S of APC binding to membranes is of minor importance in purified human system. In a model in which protein S promotes the binding of APC to phosphatidylserine containing membranes, one would expect that protein $S$ exerts its stimulatory effect preferentially at low phospholipid concentrations and on membranes with low amounts of phosphatidylserine, i.e. at conditions under which the rate of factor $\mathrm{Va}$ inactivation would be limited by the binding of APC to the membrane. The lack of such preferential stimulation may be regarded to support the altemative hypothesis that protein $\mathrm{S}$ abrogates the ability of factor Xa to protect factor Va from inactivation by APC, or that other proteins (e.g. a plasma protein S-binding protein) are required for full expression of protein S anticoagulant activity (Walker, 1986). Furthermore it is possible that protein S exhibits other anticoagulant properties, such as the recently described APC independent interaction of protein S with factor Va (Heeb et al., 1993). It is clear that the precise mechanisms of action of protein $S$ as an antithrombotic or anticoagulant remains to be established.

Snake venom proteases have been shown to be excellent tools in studying the structure-function relationship of coagulation factors. A proteolytic enzyme capable of inactivating factor Va was previously isolated from venom of the Elapid snake Naja naja oxiana (NO) (Gerads et al., 1992). The Naja naja oxiana enzyme alters factor $\mathrm{Va}$ into a molecule with greatly diminished cofactor activity (factor $\mathrm{Va}_{(\mathrm{NO})}$ ). Incubation of factor $\mathrm{Va}$ with the venom protease results in a time-dependent loss of factor Va activity with a stable residual activity of some $10-15 \%$ after 40 minutes of incubation. In Chapter 5, we describe the structural changes in factor Va following incubation with the Naja naja oxiana enzyme. The resulting change in cofactor activity of factor $\mathrm{Va}_{(\mathrm{NO})}$ was subsequently analyzed. SDS-PAGE revealed that the 
molecular weight of the heavy chain changed from $105 \mathrm{kD}$ to approximately $100 \mathrm{kD}$ after incubation with the venom protease. The light chain is not affected by incubation of factor $\mathrm{Va}$ with the $N O$ protease. Direct binding studies on planar phospholipid bilayers in an ellipsometer show that factor $\mathrm{Va}$ and factor $\mathrm{Va}_{(\mathrm{NO})}$ bound with comparable affinity to a phospholipid membrane $\left(K_{\mathrm{d}}\right.$ 's of 4.2 and $2.8 \mathrm{nM}$ respectively). From this experiment we conclude that the decreased cofactor activity of factor $\mathrm{Va}_{(\mathrm{NO})}$ in prothrombin activation is not due to reduced binding affinity of $\mathrm{Va}_{(N O)}$ for phospholipid membranes. $\mathrm{N}$-terminal amino acid sequence analysis showed that the factor $\mathrm{Va}_{(\mathrm{NO})}$ preparation contains, in addition to the known termini of the heavy and light chains of factor Va, a new amino-terminus with the amino acid sequence Asp-Arg-Leu-Glu-Pro-Glu. Matching the newly formed N-terminus in factor $\mathrm{Va}_{(\mathrm{NO})}$ with the known complete aminoacid sequence of factor $\mathrm{V}$ indicates that the venom enzyme cleaves the heavy chain between His ${ }^{682}-$ Asp $^{683}$, removing 27 amino acids from the carboxyterminal part of the heavy chain. The cofactor activities of factor $\mathrm{Va}$ and factor $\mathrm{Va}_{(\mathrm{NO})}$ were compared by measuring their ability to support factor Xa-catalyzed prothrombin activation in the presence of phospholipids and calcium ions. Both factor $\mathrm{Va}$ and $\mathrm{Va}_{(\mathrm{NO})}$ molecules stimulate the binding of factor $\mathrm{Xa}$ to negatively charged phospholipids. However, the amounts of factor Va and $\mathrm{Va}_{(\mathrm{NO})}$ required for half maximal prothrombinase complex formation differ considerably $\left(0.7 \mathrm{nM}\right.$ factor Va versus $9.42 \mathrm{nM}$ factor $\left.\mathrm{Va}_{(N O)}\right)$. Further kinetic analysis revealed that saturating amounts of both forms of factor $\mathrm{Va}$ yielded the same $k_{\text {cat }}$ for prothrombin activation. The $K_{\mathrm{m}}$ of prothrombin determined at a saturating concentration of factor $\mathrm{Va}_{(N O)}$ is approximately 3 times higher than in the case of saturation with factor $\mathrm{Va}(0.87 \mu \mathrm{M}$ versus $0.24 \mu \mathrm{M})$. These data indicate that factor $\mathrm{Va}_{(N O)}$ is impaired in its ability to interact with factor $\mathrm{Xa}$ and, to a lesser extent with prothrombin. In combination with the kinetic data this indicates that the small carboxyterminal peptide is required for optimal interaction of factor Va with prothrombin and factor $\mathrm{Xa}$.

It has been known for a long time that gel electrophoresis of purified human factor Va shows a heavy chain of $105 \mathrm{kD}$ and two slightly different light chains of 74 and $71 \mathrm{kD}$, respectively. Because factor Va consists of an equimolar complex of a heavy chain and a light chain, two different molecular forms of factor Va must exist. This posed the following questions 1 ). are these two forms of factor Val functionally identical, and 2). do they originate from two forms of circulating factor $V$ in plasma or are they generated during activation by thrombin. In Chapter 6, we addressed these questions and we describe the separation and kinetic analysis of these two 
forms of factor Va. We separated purified factor Va on a MonoS column, factor Va bound to the column and eluted in two separate peaks in a linear $\mathrm{NH}_{4} \mathrm{Cl}$ gradient. Factor Va with a $74 \mathrm{kD}$ light chain eluted at $450 \mathrm{mM} \mathrm{NH}_{4} \mathrm{Cl}$ (factor $\mathrm{Va}_{1}$ ), whereas factor $\mathrm{Va}$ with the $71 \mathrm{kD}$ light chain eluted at $750 \mathrm{mM} \mathrm{NH}_{4} \mathrm{Cl}$ (factor $\mathrm{Va}_{2}$ ) indicating that the two forms differ considerably in charge. Approximately $1 / 3$ of the factor $\mathrm{Va}$ eluted as factor $\mathrm{Va}_{1}$ and $2 / 3$ as factor $\mathrm{Va}_{2}$. When tested under reaction conditions suboptimal with respect to factor $\mathrm{Xa}$ and phospholipid concentrations the two factor $\mathrm{Va}$ forms express different cofactor activity in the prothrombinase complex. Using rates of prothrombin activation as a measure for the amount of factor $\mathrm{Xa}-\mathrm{Va}$ complexes formed, an apparent $K_{\mathrm{d}}\left(K_{1 / 2 \mathrm{Va}}\right)$ for Xa-Va complex formation of $5.9 \mathrm{nM}$ for factor $\mathrm{Va}_{1}$ and $0.45 \mathrm{nM}$ for factor $\mathrm{Va}_{2}$ was obtained. These results were obtained with phospholipids containing a low percentage anionic phospholipid (DOPS/DOPC; $5 / 95 ; \mathrm{M} / \mathrm{M} ; 2 \mu \mathrm{M}$ ). When the mole percentage PS is increased (to 20 mole $\%$ PS) the difference in factor Xa-Va complex formation disappear ( $K_{\mathrm{d}}$ app $0.047 \mathrm{nM}$ factor $\mathrm{Va}_{1}$ versus $0.044 \mathrm{nM}$ factor $\mathrm{Va}_{2}$ ). However, even with these phospholipids differences between factor $\mathrm{Va}_{1}$ and factor $\mathrm{Va}_{2}$ can be observed provided the concentration of phospholipid is sufficient low. Thus at a 20 -fold lower phospholipid concentration $(0.1 \mu \mathrm{M})$ the $\mathrm{K}_{\mathrm{d} \text { app }}$ for factor Xa-Va complex formation at the phospholipid membrane surface is 0.4 versus $0.044 \mathrm{nM}$ for factor $\mathrm{Va}_{1}$ and factor $\mathrm{Va}_{2}$ respectively. This indicates that the different efficiencies by which factors $V a_{1}$ and $\mathrm{Va}_{2}$ incorporate in the prothrombinase complex are at higher phospholipid concentrations compensated by an increased number of binding sites on the phospholipid membrane. At saturating factor Va concentrations prothrombin activation rates were essentially the same in these experiments, indicating that the two forms express the same catalytic activity in prothrombin activation but differ in their ability to form a. Xa-Va complex at the phospholipid surface. Direct binding experiments to a planar phospholipid bilayer in an ellipsometer indicated that factor $\mathrm{Va}_{2}$ bound with high affinity $\left(K_{\mathrm{d}}=0.53 \mathrm{nM}\right)$ whereas binding affinity of factor $\mathrm{Va}_{1}$ was relatively low $\left(K_{\mathrm{d}}=24 \mathrm{nM}\right)$. These results show that factor $\mathrm{Va}_{1}$ and $\mathrm{Va}_{2}$ are not identical, but differ in their ability to assemble into a Xa-Va complex on a phospholipid membrane and this difference is caused by different binding properties. Purified plasma factor $\mathrm{V}$ also binds to MonoS and elutes in two (overlapping) peaks. Upon activation of the factor $V$ containing fractions with thrombin, factor $V$ eluting at a low salt concentration in the gradient yielded the $74 \mathrm{kD}$ light chain whereas factor V eluting at a higher salt concentration yielded the $71 \mathrm{kD}$ light chain. It is concluded that the basis for the two factor Va forms is already present in the factor 
$\mathrm{V}$ molecule. When platelets are activated with thrombin and passed over MonoS, factor $\mathrm{Va}$ activity elutes at 450 and $750 \mathrm{mM} \mathrm{NH}_{4} \mathrm{Cl}$, respectively, indicating that platelet factor $\mathrm{V}$ is also heterogeneous. The conclusion from the experiments described in Chapter 6 therefore is that factor $\mathrm{V}$ is present in plasma and blood platelets in two forms which differ in the carboxyterminal domain of factor $\mathrm{V}$ (the domain from which the light chain originates). Upon activation these two factor $\mathrm{Va}$ forms neither differ in their interaction with prothrombin nor in their capacity to promote the catalytic activity of factor $\mathrm{Xa}$, but exhibit considerable differences in their ability to assemble into a membrane-bound factor Xa-Va complex caused by a different affinity for the procoagulant membrane. This heterogeneity in factor $\mathrm{V}$ molecules might be introduced during post-ribosomal processing of factor $\mathrm{V}$. Recently, Ortel and coworkers (1992) showed that the structural basis for the light chain doublet is found in the $\mathrm{C} 2$ domain. Furthermore, this group has shown that within the $\mathrm{C} 2$ domain of factor $\mathrm{Va}$ a phosphatidylserine-specific binding site is located (Ortel. et al., 1992). It is conceivable that this PS binding site is more exposed in the factor $\mathrm{Va}_{2}$ form accompanied with a relatively increased positive charge of the light chain. Further experiments are needed to resolve the question what the structural difference is between the two factor Va forms. Differences at the carbcxyterminus of factor $\mathrm{V}$ might be shown using C-terminal amino acid sequencing techniques. Alternatively differences in the carbohydrate moieties on the light chain may also be the cause of factor V heterogeneity. Questions arise whether there is a difference in activation of the two factor $\mathrm{V}$ forms. Furthermore, it is interesting to see whether activated platelets support $\mathrm{Xa}-\mathrm{Va}$ complex formation with both factor $\mathrm{Va}$ forms to the same extend.

The light chain of factor $\mathrm{Va}$ is reported to be involved in binding of activated protein $\mathrm{C}$ (APC). In factor $\mathrm{Va}$ and VIIla light chain a binding site for protein $\mathrm{C}$ has been identified. This APC binding site is located in the A3 domain of factor Va and factor VIIIa (Krishnaswamy e! al., 1986; Fay and Walker, 1989; Walker et al., 1990). It is possible that the two factor Va light chains have different binding affinities for APC. This consequently results in differences in inactivation rates for the two factor Va forms. Another phenomenon is the effect of factor Va light chain on the activation of protein C. Salem and coworkers (1984) showed that factor Va light chain accelerate protein $C$ activation by thrombin. Again it is not clear whether both factor $\mathrm{Va}$ forms accelerate this reaction to the same extend. The effects of both factor $\mathrm{Va}$ forms in the protein $\mathrm{C}$ pathway as described above remains to be examined. It might be expected that at the early stages of coagulation small amounts 
of membrane surfaces for factor Va binding are formed. In this case, factor $\mathrm{Va}_{2}$ (high affinity fraction) will bind first to the membranes forming a receptor for factor Xa. When more procoagulant membranes are generated (activated platelets) also factor $\mathrm{Va}_{1}$ will bind. It is possible that factor $\mathrm{Va}_{1}$ preferentially plays a role in the protein $\mathrm{C}$ pathway. In this light, it is conceivable that in patients with mild bleeding or thrombotic tendencies the ratio of the two factor Va forms is altered. The function of the two different forms of factor V (and factor Va) remains to be established. 



\section{Hoofdstuk 7}

\section{SAMENVATTING en SLOTOPMERKINGEN}

Deze sectie is voornamelijk bedoeld voor diegenen die het Engels niet goed beheersen, en onbekend zijn met de biochemie van de bloedstolling. Daarom geef ik in deze Nederlandse samenvatting eerst een korte inleiding over wat bloedstolling is, daarna volgt een samenvatting van de hoofdstukken, afgesloten door suggesties voor nieuw onderzoek.

Als een bloedvat beschadigd wordt treed er bloedverlies op. Bloedstolling is de omzetting door het enzym trombine van het oplosbare fibrinogeen naar het onoplosbare fibrine. Het basale beschermingsmechanisme ter voorkoming van bloedverlies omvat verscheidene cellulaire en (bloed)plasmacomponenten Daarnaast zijn er fysiologische effecten op de betrokken bloedvaten. Het stoppen van bloedingen in kleine bloedvaten kan spontaan gebeuren door het samentrekken van het bloedvat. In grote bloedvaten is een bloedprop gevormd uit bloedplaatjes en fibrine het belangrijkste mechanisme van bloedstelping. Deze hemostatische bloedprop wordt in eerste instantie gevormd door aggregatie van bloedplaatjes waarna fibrinedraden worden gevormd. Het volledig gevormde solsel bevat bloedplaatjes, rode en witte bloedlichaampjes in een fibrine netwerk. Het biochemische proces dat leid tot bloedstolling is feitelijk een serie opeenvolgende activeringen waarbij inactieve pro-enzymen geactiveerd worden tot proteolytische (eiwitsplitsende) enzymen. Een typisch aspect van deze cascade is de grote versterking als gevolg van opeenvolgende reacties. De totale versterking van dit proces kan in de orde van $10^{6}$ (miljoen) maal zijn. De enzymen die betrokken zijn bij de bloedstolling circuleren in de bloedstroom als pro-enzymen in een inactieve vorm. Ze worden geactiveerd tot actieve eiwitsplitsende enzymen door splitsing van een of twee peptide bindingen. Deze pro-enzymen worden aangeduid met R.omeinse cijfers. De geactiveerde stollingsfactor wordt aangeduid door toevoeging van een kleine ' $a$ '.

Het enzym trombine (factor Пla) wordt gevormd uit het pro-enzym protrombine (factor II), deze activering kan verlopen via twee routes, de intrinsieke 


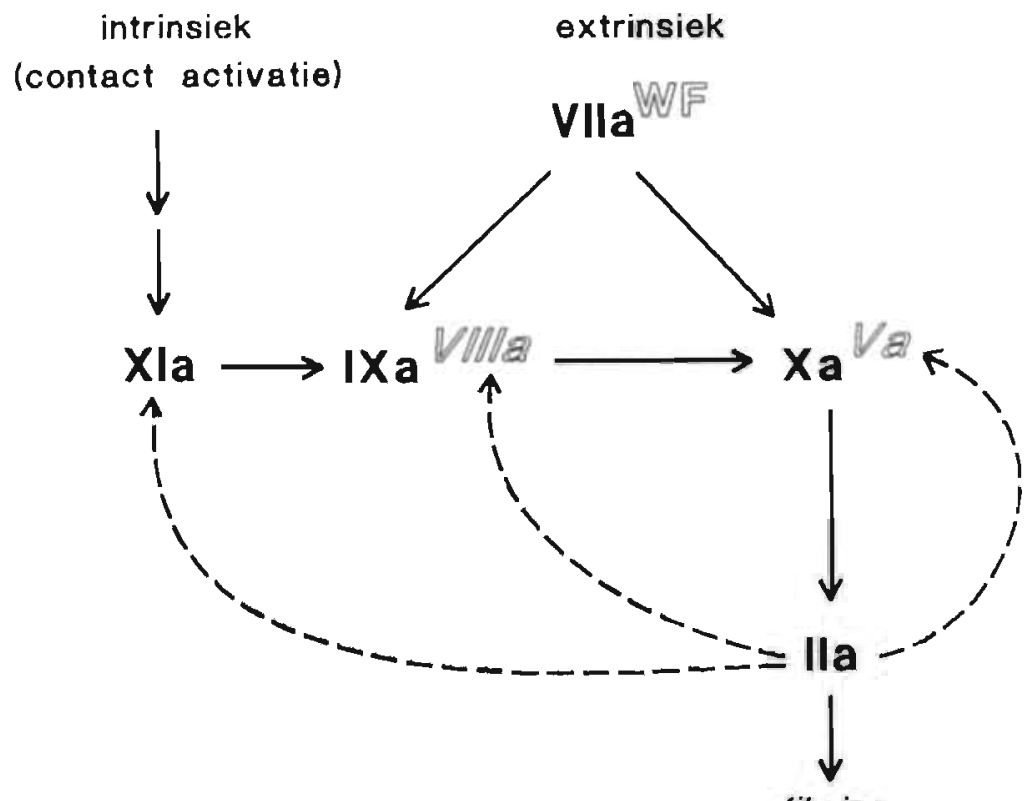

fibrine

Figuur 1. Een vereenvoudigd schema van de extrinsieke bloedstolling. Als bloed in contact komt met weefselfactor (WF) bindt factor VII uit bloed hieraan, het pro-enzym factor VII wordt omgezet naar de actieve vorm, factor VIIa. Factor VIIa activeert de pro-enzymen factor IX en X. Factor IXaa activeert ook factor $\mathrm{X}$ en is daarmee een belangrijke verbinding tussen de extrinsieke en intrinsieke stolling. Factor $\mathrm{X}$ activeert protrombine (factor II) naar trombine (factor Ilia) die fibrinogeen in het onoplosbare fibrine omzet. Trombine activeert de cofactoren V en VIII en het pro-enzym factor XI. (figuur naar Hemker and Lindhout, 1984)

en extrinsieke stolling.

De extrinsieke stolling wordt gezien als belangrijk bij het starten van het stolproces (Davie et al., 1991). Het extrinsieke stollingsproces wordt gestart wanneer bloed in contact komt met weefselfactor (WF, Figuur 1). Weefsel direct achter de wand van een bloedvat hebben weefselfactor gebonden op het celoppervlak. Bloed komt dus in contact met weefselfactor als de binnenwand van 
een bloedvat beschadigd raakt. Weefselfactor bindt dan het pro-enzym factor VII uit bloed, dan wordt factor VII actief (factor VIIa-WF complex) en kan vervolgens de proenzymen factor X en factor IX activeren (Figuur 1). Factor $\mathrm{X}$ wordt niet alleen door het VIIa-WF complex geactiveerd, maar ook door factor IXa. Deze reactie vormt een versterkingslus in de activering van factor $\mathrm{X}$, waar extrinsieke en intrinsieke stolling bij elkaar komen. Factor Xa activeert dan protrombine (factor II) naar trombine (factor IIa). Trombine is het enzym dat uiteindelijk verantwoordelijk is voor de omzetting van het in oplossing zijnde fibrinogeen naar het onoplosbare fibrine, het uiteindelijke stolsel.

De intrinsieke stolling is vermoedelijk verantwoordelijk voor het gaande houden van de trombine vorming (Davie et al., 1991). Trombine activeert het proenzym factor XI dat weer factor IX kan activeren. De intrinsieke stolling kan ook op gang gebracht worden door contact met lichaamsvreemde oppervlakken, bijvoorbeeld glas. Bij de stolling zijn ook zogenaamde cofactoren betrokken. De factoren V en VIII (zie figuur 1) zijn beide cofactoren en circuleren in het bloed in een inactieve vorm. Beide cofactoren worden geactiveerd door trombine. Deze

Tabel 1. Kinetische eigenschappen van de protrombinase (Xa-Va) en tienase ((IXa-VIIIa) complex bestanddelen. In beide gevallen is het duidelijk dat aanwezigheid van fosfolipide membranen de $K_{\mathrm{m}}$ verlaagt en dat de cofactoren de $k_{\text {cat }}$ verhogen. (Gegevens afkomstig van Rosing et al, 1980; van Dicijen et al., 1981)

\begin{tabular}{lccc}
\hline $\begin{array}{c}\text { Bestanddeel } \\
\text { Protrombinase }\end{array}$ & $\begin{array}{c}K_{\mathrm{m}} \\
(\mu \mathrm{M})\end{array}$ & $\begin{array}{c}V_{\max } \\
\mathrm{mol} \mathrm{Ila} \cdot \mathrm{s}^{-1} \cdot \mathrm{mol} \mathrm{Xa}^{-1}\end{array}$ & $\begin{array}{c}\text { Relatieve katalytische } \\
\text { Efficiëntie }\end{array}$ \\
\hline $\mathrm{Xa}$ & 84 & 0.011 & 1 \\
$\mathrm{Xa}, \mathrm{Va}$ & 34 & 6.22 & 1,400 \\
$\mathrm{Xa}$, membraan & 0.06 & 0.038 & 4,800 \\
$\mathrm{Xa}, \mathrm{Va}$, membraan & 0.21 & 32.0 & $1,130,00$ \\
\hline
\end{tabular}

\begin{tabular}{lccc}
\hline $\begin{array}{l}\text { Bestanddeel } \\
\text { Tienase }\end{array}$ & $\begin{array}{c}K_{\mathrm{m}} \\
(\mu \mathrm{M})\end{array}$ & $\begin{array}{c}V_{\max } \\
\mathrm{mol} \mathrm{Xa}^{-1} \cdot \mathrm{mol} \mathrm{IXa}^{-1}\end{array}$ & $\begin{array}{c}\text { Relatieve Katalytische } \\
\text { Efficiéntie }\end{array}$ \\
\hline IXa & 181 & $1.8 \cdot 10^{-4}$ & 1 \\
IXa, membraan & 0.058 & $4.1 \cdot 10^{-5}$ & 730 \\
IXa, VIIIa, membraan & 0.063 & 8.3 & $140,000,000$ \\
\hline
\end{tabular}


geactiveerde cofactoren, factor VIIIa en Va, hebben zelf geen enzymatische activiteit maar versterken de enzymwerking van de enzymatische stollingsfactor, respectievelijk factor $\mathrm{LXa}$ en factor $\mathrm{Xa}$, warmee ze een complex vormen (Tabel 2). De geactiveerde cofactoren binden dan met één deel van het eiwit aan een geschikt membraanoppervlak en een ander deel van het eiwit bindt dan aan een geactiveerd pro-enzym.

Het effect van de cofactor op de reactie kan beschouwd worden als het resultaat van drie effecten:

1) Een verhoging van de omzettingssnelheid $\left(k_{\mathrm{cat}}\right)$ van de reactie.

2) Het lokaliseren van het enzym-cofactor complex aan membraan oppervlakken.

3) Bevorderen van de substraatbinding aan het enzym-cofactor complex. Door de laatste twee genoemde eigenschappen kan een cofactor beschouwd worden als een membraan receptor voor zowel enzym als substraat.

Een belangrijke eigenschap van de bloedstollingsreacties is, dat ze beperkt zijn tot membraanoppervlakken. Deze membranen moeten aan bepaalde eisen voldoen, willen ze geactiveerde bloedstollingsfactoren kunnen binden. Dit soort voor de bloedstolling geschikte oppervlakken worden geleverd door geactiveerde bloedplaatjes en door beschadigde oppervlakken van cellen in de wand van het bloedvat. De aanwezigheid van membranen veranderen de kinetische eigenschappen van de activering en inactivering van stollingsfactoren (zie tabel 1 en Hoofdstuk 3). De affiniteit voor het substraat wordt aanzienlijk verhoogd door de aanwezigheid van fosfolipide membranen $\left(K_{\mathrm{m}}\right.$ gaat omhoog). De cofactoren factor Va en factor VIla hebben een relatief hoge bindingsaffiniteit voor fosfolipide membranen. Deze cofactoren kunnen worden beschouwd als 'receptor' voor de respectivelijke stollingsfactoren $\mathrm{Xa}$ en IXa op het membraanoppervlak. Een bijkomend voordeel van de lokalisatie op membraanoppervlakken is daardoor dat de reactiecomponenten in het stollingsproces elkaar gemakkelijker vinden.

Ongecontroleerde bloedstolling zou dodelijk zijn, daarom zijn er mechanismen aanwezig die de bloedstolling controleren en beperken tot de plaats van vaatwand beschadiging. Een van de controlesystemen is de aanwezigheid van enzymremmende stoffen in het bloed. Deze remmers zijn specifiek voor een bepaald enzym en leggen de activiteit van het enzym stil. Ze werken traag, waardoor er tijd zit tussen de start van de bloedstolling en de remming daarvan met als effect dat de stolling eerst goed op gang kan komen en daarna langzaam weer uitdooft. 
Het andere systeem is de protein $\mathrm{C}$ route. De protein $\mathrm{C}$ route remt de bloedstolling sterk door selectieve inactivering van de cofactoren $\mathrm{Va}$ en VIIIa (Esmon, 1984). De protein C route omvat het pro-enzym protein $\mathrm{C}$ en de cofactor protein $\mathrm{S}$. Het pro-enzym protein $\mathrm{C}$ moet net als de andere pro-enzymen eerst geactiveerd worden alvorens zijn functie uit te kunnen oefenen. Protein $\mathrm{C}$ wordt geactiveerd door trombine, zodat deze route pas geactiveerd wordt, als de bloedstolling goed op gang is gekomen en er voldoende trombine gevormd is. De cofactor protein $\mathrm{S}$ hoeft niet geactiveerd te worden.

Het doel van het onderzoek beschreven in dit proefschrift is om meer inzicht te krijgen in enkele van de mechanismen via welke de trombine vorming wordt gecontroleerd tijdens de hemostase en in het bijzonder door de plasma eiwitten factor $V(V a)$, geactiveerd protrein $C$ en protein $S$.

Het eerste hoofdstuk geeft een overzicht van het mechanisme van de bloedstolling en een literatuur overzicht van de huidige inzichten met betrekking tot het werkingsmechanisme van deze eiwitten in de regulatie van protrombineactivering.

Zuivering van factor $\mathrm{V}$ uit menselijk (humaan) plasma is beschreven in hoofdstuk 2. Factor $\mathrm{V}$ circuleert in plasma in een concentratie van ongeveer 8 $\mu \mathrm{g} / \mathrm{ml}$ ( $25 \mathrm{nM}$ ). Vanwege de labiliteit van factor $\mathrm{V}$ is complete remming van proteases gedurende de isolatie procedure essentieel. De gehanteerde isolatie procedure voor factor $\mathrm{V}$ is ten dele gebaseend op de procedure ontwikkeld door Dahlbāck (1980) en Suzuki et al. (1982). Wijzigingen die, wij hebben aangebracht in de procedure resulteerden in een verminderde isolatietijd, hogere opbrengst, hogere concentratie factor $\mathrm{V}$ en minder verontreiniging in het eind preparaat. Gel filtratie (methode orn eiwitten op grootte te scheiden) wordt nu uitgevoerd met een Superdex-200 kolom gekoppeld aan een Pharmacia FPLC systeem. Een laatste ionuitwisselings chromatografie (eiwitten worden op lading gescheiden) stap met een MonoS kolom op het FPLC systeem werd toegevoegd aan de procedure om de laatste onzuiverheden te verwijderen. Dit verbeterde onze factor $\mathrm{V}$ zuivering aanzienlijk in termen van snelheid, hoeveelheid en kwaliteit vergeleken met preparaten verkregen op lagedruk chromatografie materialen. Met behulp van deze procedure werd factor $\mathrm{V}$ meer dan 4000 maal gezuiverd uit plasma met een opbrengst van $20 \%$ in 55 uur.

Protein $\mathrm{C}$ is in geactiveerde vorm een belangrijke regulator van factor Va 
(zie Hoofdstuk 4) en VIIIa activiteit. Activering van protein $\mathrm{C}$ door niet fysiologische activatoren is van belang omdat deze activatoren gebruikt kunnen worden als gereedschap bij het bestuderen van structuur-functierelaties van protein $\mathrm{C}$, bij het maken van geactiveerd protein $\mathrm{C}$ (APC) uit protein $\mathrm{C}$, en bij het ontwikkelen van functioneel protein $C$ analyse bepalingen. Huidige kwantitatieve protein $\mathrm{C}$ bepalings methoden gebruiken een protein $\mathrm{C}$ activator geisoleerd uit het gif van de slang Agkistrodon contortrix contortrix. Deze reactie wordt sterk geremd door calcium ionen en (althans in het geval van menselijk protein $\mathrm{C}$ ) door natriumchloride ( $\mathrm{NaCl}$; keukenzout). Dit verschijnsel is in het bijzonder van belang voor het gebruik van deze activator in kwantitaieve protein $\mathrm{C}$ test systemen waardoor, door deze gevoeligheid, goed gedefinieerde reactie condities nodig zijn voor wat betreft ionsterkte en vrije calcium concentraties.

Hoofdstuk 3 beschrijft de zuivering en karakterisering van een protein $\mathrm{C}$ activator uit het slangegif van Agkistrodon halys halys. De protein $\mathrm{C}$ activator uit het Agkistrodon halys halys gif werd 533 voudig gezuiverd doormiddel van ionuitwisselingschromatografie op QAE-Sephadex A-50, affiniteitschromatografie op aprotinin-Sepharose (eiwitten worden gescheiden op grond van de specifieke bindingsaffiniteit voor het kolommateriaal, in dit geval aprotinine)en ionuitwisselingschromatografie op een MonoQ kolom in een FPLC systeem. Het gezuiverde enzym is een eiwit bestaande uit een enkele keten met een moleculair gewicht van 36.000 Dalton. Activering van protein $\mathrm{C}$ is het gevolg van een specifieke splitsing in de zware keten van het molekuul. In het geval van protein C activering door zijn fysiologische activator thrombine, is deze splitsing geidentificeerd als de verwijdering van een klein fragment van 1.400 Dalton van de aminoterminale zijde van de zware keten (Kisiel, 1979). De protein C activator gezuiverd uit Agkistrodon halys halys gif activeert protein $\mathrm{C}$ hoogst waarschijnlijk via hetzelfde mechanisme. De protein $\mathrm{C}$ activator vertoont een hoge amidolytische activiteit voor de chromogene substraten S2302 en S2238. De activiteit van de activator wordt niet beinvloed door thiolprotease of metalloprotease remmers. Aanzienlijke remming is daarentegen gemeten wanneer de protein $\mathrm{C}$ activator werd geincubeerd met de (serine) protease remmer benzamidine en soybean trypsin inhibitor (een trypsine remmer geisoleerd uit de soja boon), en vrijwel complete remming met de actieve centrum titrant pNPGB en de remmer PPACK. Dit is een indicatie dat de protein $\mathrm{C}$ activator van Agkistrodon halys halys een serine en een. histidine residu in het actieve centrum bevat hetgeen het enzym als een serine protease klassificeerd. De gezuiverde protease kan zowel menselijk als runder 
protein $\mathrm{C}$ activeren. Activering van menselijk protein $\mathrm{C}$ met een redelijke snelheid gebeurt alleen in een calcium vrij reactie medium bij een lage ionische sterkte (weinig 'zout' aanwezig). Calcium ionen remmen de activering van menselijk protein $\mathrm{C}$ met een schijnbare $K_{\mathrm{i}}$ van $0.8 \mathrm{mM}$. Natriumchloride (keukenzout) remt ook sterk de activering van menselijk protein C (met een $K_{\mathrm{i}}$ schijnbaar van $20 \mathrm{mM}$ $\mathrm{NaCl}$ ). Hiermee in tegenstelling wordt de activatie van runder protein $\mathrm{C}$ nauwelijks beinvloed door variaties in calcium of zout (natriumchloride) concentraties in het reactie medium. De schijnbare $K_{\mathrm{i}}$ 's voor calcium ion and zout (natriumchloride) remming van runder protein $C$ activering zijn respectievelijk $>10 \mathrm{mM}$ and $220 \mathrm{mM}$. Kinetische analyse van menselijk protein $\mathrm{C}$ activering door de slangegif activator (in een calcium vrij medium en bij lage zout concentratie (ionsterkte)) onthulde een schijnbare $K_{\mathrm{m}}$ voor protein $\mathrm{C}$ van $0.52 \mu \mathrm{M}$ en een omzettingssnelheid $\left(k_{\text {cat }}\right)$ van ruim 10 moleculen protein $C$ per minuut $\left(0.17 \mathrm{~s}^{-1}\right)$. De gevonden catalytische efficiëntie $\left(k_{\mathrm{cat}} / K_{\mathrm{m}}\right)$ is $3.3 * 10^{5} \mathrm{M}^{-1} \mathrm{~s}^{-1}$. Bij hogere ionsterkte wordt de activerings snelheid van menselijk protein $C$ lineair met de protein $C$ concentratie hetgeen duidt op een sterke stijging van de $K_{\mathrm{m}}$ met stijgende ionsterkte. Runder protein C wordt geactiveerd met een $K_{\mathrm{m}}$ van $0.056 \mu \mathrm{M}$ en een omzettings snelheid van 14 moleculen protein $C$ per minuut $\left(k_{\text {cat }}\right.$ is $\left.0.24 \mathrm{~s}^{-1}\right)$. De catalytische efficiëntie van runder protein $C$ activering $\left(k_{\mathrm{cat}} / K_{\mathrm{m}}=4.3 * 10^{6} \mathrm{M}^{-1} \mathrm{~s}^{-1}\right)$ is 13 mal beter dan van menselijk protein $\mathrm{C}$ activering. De reden daarvoor is een lagere $K_{\mathrm{m}}$ van de gif activator voor runder protein $\mathrm{C}$. Deze cijfers zijn een indicatie voor een grote conformatie en/of een structuurverschil tussen menselijk en runder protein $\mathrm{C}$ bij fysiologische zout sterkte. Het lijkt er bovendien op dat in tegenstelling tot nunder protein $\mathrm{C}$, de conformatie van menselijk protein $\mathrm{C}$ aanzienlijk verandert met veranderende ionsterkte. Protein $\mathrm{C}$ activering door trombine wordt ook geremd door calcium ionen, maar als thrombomoduline aanwezig is, heeft deze reactie juist calcium nodig.

Factor Va cofactor activiteit in vivo (in levende organismen), wordt afgebroken door geactiveerd protein C (APC) in samenwerking met protein S. In hoofdstuk 4 hebben we het effect van calcium, phospholipiden (kunstmatige nabootsing van cel oppervlakken) en protein $\mathrm{S}$ op de kinetische parameters van APC-gekatalyseerde factor $\mathrm{Va}$ geanalyseerd. Hierbij gebruikmakend van gezuiverde menselijke eiwitten. In overeenstemming met eerdere publicaties vonden wij dat factor $\mathrm{Va}$ inactivering door APC niet afhankelijk is van de aanwezigheid van fosfolipiden en protein S. De reactie, in afwezigheid van fosfolipiden, vereist de aanwezigheid van calcium. Bij de optimale calcium 
concentratie ( $2 \mathrm{mM}$ ) verloopt de reactie met een tweede orde reactie constante van $6.1 \times 10^{5} \mathrm{M}^{-1} \mathrm{~s}^{-1}$. De inactiveringsreactie in een fosfolipide vrij reactie medium heeft een hoge $K_{\mathrm{m}}$ voor factor $\mathrm{Va}(>78 \mathrm{nM})$. APC-gekatalyseerde factor Va inactivering wordt aanzienlijk versneld door negatief geladen membraan oppervlakken. De mate waarin de fosfolipiden de reactie stimuieren is afhankelijk van de fosfolipide concentratie en samenstelling. Optimale snelheden van factor $\mathrm{Va}$ inactivering worden verkregen in aanwezigheid van $10 \mu \mathrm{M}$ fosfolipide vesicles met een hoog percentage anionische (negatief geladen) fosfolipiden. Onder deze reactie condities werd de APC gekatalyseerde factor $\mathrm{Va}$ inactivering gekarakteriseerd door een schijnbare tweede orde constante van $1.4 \times 10^{8} \mathrm{M}^{-1} \mathrm{~s}^{-1}$. Dit is 230 maal hoger dan de reactiesnelheid in afwezigheid van fosfolipiden in het reactie medium. Het stimulerend effect van fosfolipiden op APC gekatalyseerde factor Va inactivering vertoont een duidelijk optimum voor fosfolipid concentratie en fosfolipid (DOPS/DOPC) compositie. Membranen die enkel zijn opgebouwd uit het neutrale fosfolipide fosfatidylcholine zijn niet in staat de APC gekatalyseerde factor $\mathrm{Va}$ inactivering te versnellen. Dus om factor $\mathrm{Va}$ inactivering te stimuleren moeten membranen negatief geladen (anionische) fosfolipiden bevatten. Het vermogen om factor Va inactivering te stimuleren is niet beperkt tot fosfatidylserine (een negatief geladen fosfolipide)bevattende membranen aangezien membranen met andere negatief geladen fosfolipiden ook de factor $\mathrm{Va}$ inactivering aanzienlijk stimuleren. Het vermogen van verschillende fosfolipiden om de factor $\mathrm{Va}$ inactivering te stimuleren neemt toe met de volgorde phosphatidylethanolamine $<$ olie zuur < fosfatidyl zuur $<$ fosfatidylglycerol $<$ fosfatidylmethanol $<$ fosfatidylserine. Versnelling van de APC gekatalyseerde factor $\mathrm{Va}$ inactivering door negatief geladen membranen is waarschijnlijk een gevolg van het feit dat APC en factor $\mathrm{Va}$ allebei binden aan dergelijke membranen. Dit makt de inactivering van membraan gebonden factor Va dooi membraan gebonden APC mogelijk. De schijnbare $K_{\mathrm{m}}$ voor factor $\mathrm{Va}$ is aanzienlijk verlaagd in aanwezigheid van fosfolipide membranen in het reactiemedium. Als de concentratie fosfolipiden wordt verhoogd is er een parralelle verhoging van de $K_{\mathrm{m}}$. Ook de maximale reactie snelheid $\left(V_{\max }\right)$ van A.PC gekatalyseerde inactivering van factor $\mathrm{Va}$ blijkt een functie te zijn van de fosfolipide concentratie. De $V_{\max }$ neemt toe met de concentratie fosfolipide aanwezig in het reactie medium en bereikt een plateau bij $10 \mu \mathrm{M}$ fosfolipide.

Dit suggereert duidelijk, dat in aanwezigheid van fosfolipide (membraan)oppervlak gebonden factor Va geinactiveerd wordt door oppervlak gebonden APC. Bovendien geven de experimenten beschreven in Hoofdstuk 4 
duidelijk aan dat bevordering van protein $\mathrm{S}$ voor het binden van APC aan membranen van geringe betekenis is in het gezuiverde menselijke systeem.

In een model waarin protein $\mathrm{S}$ de binding van $\mathrm{APC}$ aan fosfatidylserine bevattende membranen bevordert zou men verwachten dat protein $\mathrm{S}$ het stimulerend effect bij voorkeur zou laten zien bij lage fosfolipide concentraties en op membranen met weinig fosfatidylserine, met andere woorden onder die condities waarbij de snelheid van factor $\mathrm{Va}$ inactivering wordt beperkt door de binding van APC aan het membraan. De afwezigheid van stimulatie onder beperkende condities mag beschouwd worden als een ondersteuning van de alternatieve hypothese dat protein $\mathrm{S}$ het vermogen van factor $\mathrm{Xa}$ om factor $\mathrm{Va}$ te beschermen tegen inactivering door APC opheft, of dat andere eiwitten (bijvoorbeeld een plasma protein $\mathrm{S}$ bindend eiwit) nodig zijn voor het tot volle expressie brengen van de antistollings activiteit van protein S (Walker, 1986). Bovendien is het mogelijk dat protein S andere antistollings eigenschappen bezit, zoals de recentelijk beschreven APC onafhankelijke interactie van protein S met factor Va (Heeb et al., 1993). Het is duidelijk dat het werkings mechanisme van protein $\mathrm{S}$ als antistollings eiwit nog niet vastgesteld is.

Proteolytische enzymen uit slangegif blijken uitstekend gebruikt te kunnen worden als gereedschap bij het bestuderen van structuur en functie relaties in stollingsfactoren. Een proteolytisch enzym instaat tot het inactiveren van factor Va is eerder geisoleerd uit het gif van de slang Naja naja oxiana (NO) (Gerads et al., 1992). Het enzym uit Naja naja oxiana gif verandert factor Va in een molecuul met sterk verminderde cofactor activiteit (factor $\mathrm{Va}_{(N O)}$ ). Incuberen van factor $\mathrm{Va}$ met het gif protease resulteert in een tijds afhankelijk verlies van factor $\mathrm{Va}$ activiteit met een stabiele overblijvende activiteit van $10-15 \%$.

In Hoofdstuk 5 beschrijven we de structurele veranderingen in factor $\mathrm{Va}$ als gevolg van incubatie met het Naja naja oxiana enzym. De ontstane verandering in cofactor activiteit van factor $\mathrm{Va}_{(N O)}$ werd daama geanalyseerd. SDS-PAGE heeft aan het licht gebracht dat de moleculaire massa van de zware keten veranderde van $105 \mathrm{kD}$ naar ongeveer $100 \mathrm{kD}$ na incubatie met het gif protease. De lichte keten verandert niet na incubatie van factor Va met de $N O$ protease. Binding studies aan vlakke fosfolipide dubbellagen in een ellipsometer lieten zien dat factor Va and factor $\mathrm{Va}_{(N O)}$ met gelijkwaardige affiniteit binden aan het fosfolipide oppervlak ( $K_{\mathrm{d}}$ 's van respectievelijk 4.2 en $2.8 \mathrm{nM}$ ). Uit dit experiment concluderen we dat de verlaagde cofactor activiteit van factor $\mathrm{Va}_{(N O)}$ in de protrombine activering niet veroorzaakt wordt door verlaagde bindingsaffiniteit van factor $\mathrm{Va}_{(N O)}$ aan 
fosfolipide membranen. N-terminale aminozuur sequentieanalyse onthulde dat de factor $\mathrm{Va}_{(N O)}$ preparaten naast de bekende termini van de zware en lichte keten van factor Va een nieuwe terminus was gevormd met de aminozuur volgorde Asp-ArgLeu-Glu-Pro-Glu. Vergelijking van de nieuw gevormde $\mathrm{N}$-terminus in factor $\mathrm{Va}_{(\mathrm{NO})}$ met de uit de literatuur bekende complete aminozuur volgorde van factor $\mathrm{V}$ laten zien dat het slangegif enzym de zware keten splitst tussen His ${ }^{682}-\mathrm{Asp}^{683}$. Hierdoor wordt een stuk van 27 aminozuren afgesplitst van de carboxyterminale zijde van de zware keten. De cofactor activiteiten van factor $\mathrm{Va}$ en factor $\mathrm{Va}(\mathrm{NO})$ zijn met elkaar vergeleken door het meten van het vermogen om factor Xa gekatalyseerde protrombine activering te ondersteunen in aanwezigheid van membranen (fosfolipiden) en calcium. Factor $\mathrm{Va}$ and $\mathrm{Va}_{(N O)}$ allebei stimuleren de binding van factor $\mathrm{Xa}$ aan negatief geladen membraan oppervlakken. De hoeveelheden van factor $\mathrm{Va}$ en $\mathrm{Va}_{(N O)}$ die nodig zijn voor half maximale vorming van het protrombinase complex verschilt aanzienlijk $(0.7 \mathrm{nM}$ factor Va versus $9.42 \mathrm{nM}$ factor $\left.\mathrm{Va}_{(N O)}\right)$. Verdere kinetische analyses tonen dat verzadigende hoeveelheden van beide vormen van factor $\mathrm{Va}$ in een zelfde $k_{\text {cat }}$ voor protrombin activering resulteerde. De $K_{\mathrm{m}}$ voor protrombine bepaald bij verzadigende concentraties van factor $\mathrm{Va}_{(N O)}$ is ongeveer 3 maal hoger dan in het geval dat een verzadigende concentratie factor Va werd gebruikt $(0.87 \mu \mathrm{M}$ versus $0.24 \mu \mathrm{M})$. Deze gegevens geven aan dat factor $\mathrm{Va}_{(\mathrm{NO})}$ sterk verzwakt is in zijn mogelijkheid om met factor $\mathrm{Xa}$ een interactie aan te gaan en dit geld in mindere mate voor de interactie met protrombine. In combinatie met de kinetische gegevens geeft dit aan dat het kleine carboxyterminale fragment van de zware keten van factor Va nodig is voor een optimale interactie van factor Va met protrombine en factor Xa.

Het is al lange tijd bekend dat gezuiverd factor Va op PA-gels (een methode om eiwitten op grootte te scheiden en door kleuring zichtbaar te maken; zie b.v. hoofdstuk 2, figuur 1) een zware keten van $105 \mathrm{kD}$ en twee enigszins verschillende lichte ketens van respectivelijk 74 en $71 \mathrm{kD}$ laat zien. Omdat factor Va bestaat uit een complex met een zware en een lichte keten, moeten er twee verschillende vormen van factor Va bestaan. Dit stelde ons voor de volgende vragen !) Zijn deze twee vormen van factor $\mathrm{Va}$ functioneel identiek en 2) Zijn ze afkomstig van twee vormen in bloed circulerend factor $\mathrm{V}$ of worden ze gegenereerd tijdens activatie door trombine.

In Hoofdstuk 6 richten we ons op deze vragen en beschrijven we de scheiding en kinetische analyse van de twee factor Va vormen. We scheiden gezuiverd factor Va op een MonoS kolom, factor Va bond aan de kolom en liet los 
in gescheiden pieken in een lineair zout (ammoniumchloride; $\mathrm{NH}_{4} \mathrm{Cl}$ ) gradient.

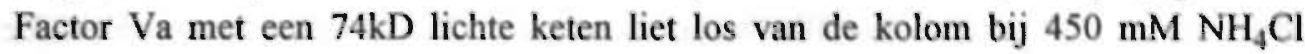
$\left(\right.$ factor $\mathrm{Va}_{1}$ ) factor $\mathrm{Va}$ met de $71 \mathrm{kD}$ lichte keten spoelde daarentegen van de kolom bij $750 \mathrm{mM} \mathrm{NH} 4 \mathrm{Cl}$ (factor $\mathrm{Va}_{2}$ ). Dit geeft aan dat de twee factor $\mathrm{Va}$ vormen aanzienlijk in lading verschillen. Ongeveer $1 / 3$ van de factor $\mathrm{Va}$ elueerde als factor $\mathrm{Va}_{1}$ en $2 / 3$ als factor $\mathrm{Va}_{2}$. De twee factor $\mathrm{Va}$ vormen vertonen verschillende cofactor activiteiten in het protrombinase complex als ze getest worden onder suboptimale omstandigheden voor wat betreft de factor $\mathrm{Xa}$ en fosfolipide concentraties. Gebruikmakend van de snelheid van protrombine activering als een maat voor de hoeveelheid factor Xa-Va complexen gevormd, werd een schijnbare $K_{\mathrm{d}}\left(K_{1 / 2 \mathrm{Va}}\right)$ voor Xa-Va complex vorming van $5.9 \mathrm{nM}$ voor factor $\mathrm{Va}_{1}$ en $0.45 \mathrm{nM}$ voor factor $\mathrm{Va}_{2}$ gevonden. Deze resultaten werden verkregen met membranen waarin een laag percentage negatief geladen fosfolipide aanwezig was (DOPS/DOPC; $5 / 95 ; \mathrm{M} / \mathrm{M} ; 2 \mu \mathrm{M}$ ). Wanneer het percentage van de negatief geladen fosfolipide werd verhoogd (tot $20 \mathrm{~mole} \% \mathrm{PS}$ ) verdween het verschil in de factor Xa-Va complex vorming ( $K_{\mathrm{d} \text { schijnbaar }} 0.047 \mathrm{nM}$ factor $V a_{1}$ versus $0.044 \mathrm{nM}$ factor $\mathrm{Va}_{2}$ ). Maar zelfs bij deze membranen kan een verschil tussen factor $\mathrm{Va}_{1}$ en factor $\mathrm{Va}_{2}$ gevonden worden als de concentratie fosfolipiden maar laag genoeg wordt. Bij een 20 maal lagere fosfolipide concentratie $(0.1 \mu \mathrm{M})$ is de $\mathrm{K}_{\mathrm{d}}$ schijnbaar voor factor Xa-Va complex vorming is respectivelijk 0.4 versus $0.044 \mathrm{nM}$ for factor $\mathrm{Va}_{1}$ and factor $\mathrm{Va}$.

Dit betekent dat de verschillende efficienties waarmee de factoren $\mathrm{Va}_{1}$ and - $\mathrm{Va}_{2}$ in het protrombinase complex incorporeren bij hogere fosfolipideconcentraties, gecompenseerd worden door een verhoogd aantal bindingsplaatsen. Bij verzadigende factor Va concentraties zijn de snelheden van protrombine activering voor al deze experimenten gelijk. Dit wijst er op dat de twee factor Va vormen dezelfde catalytische activiteit hebben in protrombine activering maar verschillen in de mogelijkheid om Xa-Va complexen te vormen op een fosfolipidle oppervlak. Directe bindingsexperimenten aan vlakke fosfolipide dubbellagen in een ellipsometer lieten zien dat factor $\mathrm{Va}_{2}$ bond met hoge affiniteit $\left(K_{\mathrm{d}}=0.53 \mathrm{nM}\right)$ terwijl de bindingsaffiniteit van factor $V a_{1}$ vrij laag was $\left(K_{\mathrm{d}}=24 \mathrm{nM}\right)$. Deze resultaten geven duidelijk aan dat factor $\mathrm{Va}_{1}$ and $\mathrm{Va}_{2}$ niet identiek zijn maar verschillen in de mogelijkheid om te assembleren in een Xa-Va complex op een fosfolipide membraan en dat dit verschil veroorzaakt wordt door een verschil in membraan bindings eigenschappen. Gezuiverd factor $\mathrm{V}$ bind ook aan MonopS en spoelt in een zout gradient van de kolom in twee: (overlappende) pieken. $\mathrm{Na}$ 
activering van de factor $\mathrm{V}$ bevattende fracties met trombine bleek de factor $\mathrm{V}$ die het eerste van de kolom spoelde factor $\mathrm{Va}$ met een $74 \mathrm{kD}$ lichte keten opleverde terwijl de bij meer zout eluerende factor $V$ resulteerde in een factor $V a$ met een 71 $\mathrm{kD}$ licht chain. Hieruit werd geconcludeerd dat de basis voor de twee factor $\mathrm{Va}$ vormen reeds aanwezig is in het factor $\mathrm{V}$ molecuul. Als trombine geactiveerde bloedplaatjes op een MonoS kolom gebracht wordt blijkt dat factor Va activiteit van de kolom elueert bij respectievelijk 450 and $750 \mathrm{mM}$ zout $\left(\mathrm{NH}_{4} \mathrm{Cl}\right)$. Dit geeft an dat bloedplaatjes factor $\mathrm{V}$ ook heterogeen is.

De conclusie uit de experimenten beschreven in Hoofdstuk 6 is dat factor V aanwezig in plasma en bloedplaatjes in twee vormen voorkomt die verschillen in het carboxyterminale domein van factor $\mathrm{V}$ (Dat is het domein waaruit de lichte keten gevormd wordt). Na activering verschillen de twee factor Va vormen niet in de interactie met protrombine of in de capaciteit om de catalytische activiteit van factor Xa te bevorderen, maar ze verschillen wel aanzienlijk in de mogelijkheid om te assembleren in een membraan gebonden factor Xa-Va complex veroorzaakt door verschil in bindingsaffiniteit voor membranen. Deze heterogeniteit in het factor $\mathrm{V}$ molecuul zou geïntroduceerd kunnen zijn tijdens post-ribosomale behandeling van factor $\mathrm{V}$.

Recentelijk heeft Ortel en zijn medewerkers laten zien dat de structurele basis van de twee lichte ketenvormen op het $\mathrm{C} 2$ domein ligt. Hij liet verder zien dat op dit $\mathrm{C} 2$ domein van factor Va een fosfatidylserine specifieke bindingsplaats is gelocaliseerd (Ortel et al., 1992). Het is aannemelijk dat deze fosfatidylserine bindingsplaats beter beschikbaar is in factor $\mathrm{Va}_{2}$, gepaard gaande met een relatief verhoogde positieve lading van de lichte keten.

Nadere experimenten zijn nodig om de vraag op te lossen wat het structurele verschil is tussen de twee factor Va vormen. Verschillen aan de carboxyterminale zijde van factor $\mathrm{V}$ zouden zichtbaar gemaakt kunnen worden met de recent ontwikkelde C-terminale aminozuur volgorde bepalingstechnieken. Verschillen in de koolhydraat ketens aan de lichte keten kunnen ook de oorzaak zijn van de factor $\mathrm{V}$ heterogeniteit. Een interessante vraag is of er een verschil is in activering van de twee factor $\mathrm{V}$ vormen. Verder is het interessant om te zien of op geactiveerde bloedplaatjes factor $\mathrm{Xa}-\mathrm{Va}$ complex vorming voor beide factor Va vormen verschillend is.

In de literatuur is gerapporteerd dat de lichte keten van factor $\mathrm{Va}$ betrokken is bij de binding van geactiveerd protein $\mathrm{C}$ (APC) aan factor Va. Zowel in factor Va en factor VIIla lichte keten is een bindingsplaats geidentificeerd. Deze APC 
bindingsplaats ligt op het A3 domein van factor Va en VIIIa (Krishnaswamy et al., 1986; Fay and Walker, 1989; Walker et al., 1990). Het is mogelijk dat de twee factor Va vormen verschillende bindingsaffiniteit hebben voor APC. Dit heeft tot gevolg dat er verschillende inactiverings snelheden zijn voor de twee vormen van factor Va. Een ander fenomeen is het effect van de lichte keten van factor Va op de activering van protein C. Salem en medewerkers (1984) lieten zien dat de factor Va lichte keten de activering van protein $\mathrm{C}$ door trombine versneld. Ook hier is het (nog) niet duidelijk of beide factor Va vormen in gelijke mate deze reactie versnellen. De effecten van beide factor $\mathrm{Va}$ vormen in de protein $\mathrm{C}$ route, zoals hierboven beschreven, moeten nog onderzocht worden. Verondersteld mag worden dat in de vroege fase van de bloedstolling kleine hoeveelheden geschikte membraan oppervlakken voor factor $\mathrm{Va}$ binding worden gevormd. In dat geval zal factor $\mathrm{Va}_{2}$ (de hoge affiniteit fractie) als eerste zal binden aan het membraan waar het een receptor vormt voor factor Xa. Als er meer geschikte membraan oppervlakken worden gegenereerd (geactiveerde bloedplaatjes) zal ook factor $\mathrm{Va}_{1}$ binden. Het is mogelijk dat factor $\mathrm{Va}_{1}$ een belangrijke rol speelt in de protein $\mathrm{C}$ route. In dit licht is het aannemelijk dat in patienten met lichte bloedings of trombose neigingen de verhouding van de twee factor Va vormen mogelijk is veranderd. De functie van de twee verschillende factor $V$ (en factor Va vormen) moet nog opgehelderd worden. 



\section{REFERENCES}

Amphlett GW, Kisiel W, and Castellino FJ (1981) Interaction of calcium with bovine plasma protein C. Biochemistry 20,2156-2161

Andree HAM (1992) Phospholipid binding and anticoagulant action of annexin V. Thesis University of Limburg, Maastricht, The Netherlands.

Annamalai AE, Rao AK, Chui HC, Wang D, Dutta-Roy AK, walsh PN, and Colman RW (1987) Epitope mapping of functional domains of human factor $\mathrm{Va}$ with human and murine monoclonal antibodies. Evidence for the interaction of the heavy chain with factor $\mathrm{Xa}$ and calcium. Blood 70, $139-146$

Böttcher CJF, van Gent, CM, and Pries, C (1961) Anal Chim Acta 24, 203-207

Berg OG, and von Hippel PH (1985) Diffusion-controled macromolecular interactions. Ann Rev Biophys Chem 14, 131-160

Bloom JW, Nesheim ME, and Mann KG (1979) Phospholipid-binding properties of bovine factor V and factor Va. Biochemistry 18, 4419-4425

Bock PE, Craig PA, Olson ST, and Singh P (1989) Isolation of human blood coagulation alphafactor $\mathrm{Xa}$ by soybean trypsin inhibitor-sepharose chromatography and its active site titration with fluorescein mono-p-guanidinobenzoate. Arch Biochem Biophys 273, 375-388

Bolhuis PA, Hakvoort TBM, Breederveld K, Mochtar LA, Ten Cate JW (1979) Isolation and partial characterization of human factor Va. Biochim Biophys Acta 578, 23-30

Borowski W, Furie BC, Bauminger S, and Furie B (1986) Prothrombin requires two sequential metal-dependent conformational transitions to bind phospholipid. J Biol Chem 261, 14969-14975

Branson HE, Katz J, Marble R, and Griffin JH (1983) Inherited protein C deficiency and coumarineresponsive chronic relapsing purpura fulminans in a new born infant. Lancet 8360, 1165-1168

Briēt E, Broekmans AW, and Engesser L (1988) Hereditary protein S deficiency. From: Protein C and related proteins. Biochemical and clinical aspects. Ed RM Bertina. Churchill Livingstone NY pp. 203-212.

Broze GJ, Leykam JE, Schwartz BD, and Miletich (1985) Purification of human tissue factor. $J$ Biol Chem 260, 10917-10921

Broze GJ, Warren LA, Girard. JJ, and Miletich JP (1987) Isolation of the lipoprotein associated coagulation inhibitor produced by HepG2 (human hepatoma) cells using bovine factor Xa affinity chromatography. Thromb Res 48, 253-259

Broze GJ, Girard TJ, and Novotny WF (1990) Regulation of coagulation by a multivalent Kunitztype inhibitor. Biochemistry 29, 7539-7546 
Cerveny TJ, Fass DN, and Mann KG (1984) Synthesis of coagulation factor V by cultured aortic endothelium. Blood 63, 1467-1472

Chase T, and Shaw E (1969) Comparison of the esterase activities of trypsin, plasmin, and thrombin on guanidinobenzoate esters. Titration of the enzymes. Biochemistry 8, 2212-2224

Chippaux J-P, Williams V, and White J (1991) Snake venom variability: Methods of study, results and interpretation. Toxicon 29, 1279-1304

Church WR, Jernigan RL, Toole J, Hewick RM, Knopf J, Knutson GJ, Nesheim ME, Mann KG, and Fass DN (1984) Coagulation factors V and VIII and ceruloplasmin constitute a family of structurally related proteins. Proc Natl Acad Sci USA 81, 6934-6937

Comfurius P, and Zwaal RFA (1977) The enzymatic synthesis of phosphatidylserine and purification by CM-cellulose column chromatography. Biochim Biophys Acta $\mathbf{4 8 8 , 3 6 - 4 2}$

Comp PC, Nixon RR, and Esmon CT (1984) Determination of functional levels of protein C, an antithrombotic protein, using thrombin-thrombomodulin complex. Blood 63, 15-21

Comp PC, Nixon RR, Cooper MR, and Esmon CT (1984) Familial protein S deficiency is associated with recurrent thrombosis. J Clin Invest 74, 2082-208

Comp PC, and Esmon CT (1981) Generation of fibrinolytic activity by infusion of activated protein $\mathrm{C}$ into dogs. J Clin Invest $68,1221-1228$

Cripe LD, Moore KD, and Kane WH (1992) Structure of the gene for human coagulation factor V. Biochemistry 31, 3777-3785

Cuypers PA, Corsel JW, Janssen MP, Kop JMM, Hermens WT, and Hemker HC (1983) The adsorption of prothrombin to phosphatidylserine multilayers quantitated by ellipsometry, $J$ Biol Chem 258, 2426-2431

Dahlbăck B, Carlsson M, and Svensson PJ (1993) Familial thrombophilia due to a previously. unrecognized mechanism characterized by poor anticoagulant response to activated protein $\mathbf{C}$ : Prediction of a cofactor to activated protein C. Proc Natl Acad Sci USA. 90, 1004-1008

Dahlbăck B (1980) Human coagulation factor V purification and thrombin-catalyzed activation. $J$ Clin Invest 66, 583-591

Dahlbäck B (1983) Purification of human vitamin K-dependent protein S and its limited proteolysis of thrombin. Biochem J 209, 837-846

Dahlbăck B (1986) Bovine coagulation factor V visualized with electron microscopy. Ultrastructure of the isolated activated forms and of the activation. fragments. J Biol Chem 261, 9495-9501 
Davie EW, Fujikawa K, and Kisiel W (1991) The coagulation cascade: initiation, maintenance, and regulation. Biochemistry 30, 10363-10370

de Kruijff B, Cullis PR, and Radda GK (1975) Differential scanning calorimetry and ${ }^{31}$ P NMR studies on sonicated and unsonicated phosphatidylcholine liposomes. Biochim Biophys Acta 406, 620

DiScipio RG, Hermodson MA, Yates SG, and Davie EW (1977) A comparison of human prothrombin, factor IX (Christmas factor), factor X (Stuart factor), and protein S. Biochemistry 16, 698-706

Eisenthal R, and Cornish-Bowden A (1974) The direct linear plot. A new graphical procedure for estimating enzyme kinetic parameters. Biochem $J$ 139, 715-720

Esmon CT, and Owen WG (1981) Identification of an endothelial cell cofactor for thrombincatalyzed activation of protein C. Proc Natl Acad Sci USA 78, 2249-2252

Esmon CT, and Owen WG (1981) Identification of an endothelial cell cofactor for thrombincatalyzed activation of protein C. Proc Nall Acad Sci USA 78, 2249-2252

Esmon CT (1979) The subunit structure of thrombin-activated factor V. Isolation of activated factor $\mathrm{V}$, seperation of subunits, and reconstitution of biological activity. J Biol Chem 254, 964-973

Esmon CT (1983) Protein C: Biochemistry, physiology, and clinical implications. Blood 62, 11551158

Esmon CT (1989) The roles of protein $C$ and thrombomodulin in the regulation of blood coagulation. J Biol Chem 264, 4743-4746

Esmon NL, Owen WG, van Esmon CT (1982) Isolation of a membrane-bound cofactor for thrombincatalyzed activation of protein C. J Biol Chem $257,859-864$

Esmon NL, DeBault LE, and Esmon CT (1983) Proteolytic formation and properties of $y$ carboxyglutamic acid-domainless protein C. J Biol Chem 259, 5548-5553

Exner T, and Vaasjoki R (1988) Characterisation and some properties of the protein C activator from Agkistrodon contortrix contoririx venom. Thromb and Haemostas 59, 40-44

Fair DS, and Marlar RA (1986) Biosynthesis and secretion of factor VII, protein C, protein S, and the protein $\mathrm{C}$ inhibitor from a human hepatoma cell line. Blood $67,64-70$

Fay PJ, Chavin SI, Schroeder D, Yuong FE, and Marder VJ (1982) Purification and characterization of a highly purified human factor VIII consisting of a single type of polypeptide chain. Proc Nanl Acad Sci USA 79, 7200-7204 
Foster DC, and Davie EW (1984) Characterization of a cDNA coding for human protein C. Proc Natl Acad Sci USA 81, 4766-4770

Foster DC, Yoshitake S, and Davie EW (1985) The nucleotide sequence of the gene for human protein C. Proc Natl Acad Sci USA 82, 4673-4677

Fujikawa K, Legaz, ME, and Davie EW (1972) Bovine factor $X_{1}$ (Stuart factor). Mechanism of activation by protein from Russell's viper venom. Biochemistry 11, 4892-4899

Fulcher CA, Gardiner JE, Griffin JH, and Zimmerman TS (1984) Proteolytic inactivation of human. factor VIII procoagulant protein by activated human protein $\mathrm{C}$ and its analogy with factor V. Blood 63, 486-489

Furie B, and Furie BC (1988) The molecular basis of blood coagulation. Cell 53, 505-518

Furie BMD, and Furie BC (1993) Molecular and cellular biology of blood coagulation. $J$ Med 1992 , 800-806

Gerads I, Tans G, Yukelson LY, Zwaal RFA, and Rosing J (1992) Activation of bovine factor V by an activator purified from the venom of Naja oxiana. Toxicon 30, 1065-1079

Giesen PLA (1992) Production of thrombin at macroscopic surfaces. Thesis University of Limburg, Maastricht, The Netherlands.

Griffin, JH (1988) Protein C and protein S defects in thromboembolic disease. in Current Advances in Vitamin K. Research (Suttie JW, Ed.) pp 97-100 Elsevier Publ Comp Inc, USA, New York

Griffin JH, Evatt B, Zimmerman TS, Kleiss AJ, and Wideman C (1981) Deficiency of protein C in congenital thrombotic disease. J Clin Invest' 68, 1370-1373

Griffin JH, Mosher DF, Zimmerman TS, and Kleiss AJ (1982) Protein C, an antithrombotic protein, is reduced in hospitalized patients with intravascular coagulation. Blood 60, 261-264

Griffith MJ, Reisner HM, Lundblad RL, and Roberts HR (1982) Measurement of human factor IXa activity in an isolated factor $\mathrm{X}$ activation system. Thromb Res 27, 289-301

Gruber A, Griffin JH, Harker LA, and Hanson SR (1989) Inhibition of platelet-dependent thrombus formation by human activated protein $\mathrm{C}$ in a primate model. Blood $73,639-642$

Guha A, Bach R, Koningsberg W, and Nemerson Y (1986) Affinity purification of human tissue factor: Interaction of factor VII and tissue factor in detergent micelles. Proc Natl Acad Sci USA 83. 299-305

Guinto ER, and Esmon CT (1982) Formation of a calcium-binding site on bovine activated factor $V$ following recombination of the isolated subunits. J Biol Chem 257, 10038-10043 
Guinto ER, and Esmon CT (1984) Loss of prothrombin and of factor Xa-factor Va interactions upon inactivation of factor Va by activated protein C. J Biol Chem 259, 13986-13992

Guinto ER, Esmon CT, Mann KG, and MacGillivray RTA (1992) The complete cDNA sequence of bovine coagulation factor V. J Biol Chem 267, 2971-2978

Hackeng TM, Hessing, van 't Veer C, Meijer-Huizinga F, Meijers JCM, de Groot PG, van Mourik JA, and Bouma BN (1993) Protein S binding to human endothelial cells is rtequired for expression of cofactor activity for activated protein C. J Biol Chem 268, 3993-4000

Hanahan DJ, Rolfs MR, and Day WC (1972) Biochim Biophys Acta 286, 205-211

Harris KW, and Esmon CT (1985) Protein S is required for bovine platelets to suppont activated protein $C$ binding and activity. $J$ Biol Chem 260, 2007-2010

Heeb MJ, and Griffin JH (1988) Physiologic inhibition of human activated protein C by $\alpha$. Iantitrypsin. J Biol Chem 263, 11613-11616

Heeb MJ,and Griffin JH (1988) The biochemistry of protein S. From Protein C and related proteins. Ed RM Bertina. Churchill Livingstone NY pp 55-70

Heeb MJ, España F, and Griffin JH (1989) Inhibition and complexation of activated protein C by two major inhibitors in plasma. Blood 73, 446-454

Heeb MJ, Mesters RM, Tans G, Rosing, and Griffin JH (1993) Binding of protein $S$ to factor Va: associated with inhibition of prothrombinase that is independent of activated protein $\mathrm{C}$. $J$ Biol Chem! 268, 2872-2877

Hemker HC, Esnouf MP, Hemker PW, Swart ACW, and Macfarlane RG (1967) Formation of prothrombin converting activity. Nature 215, 248-25.1

Hemker HC, and Kahn MJP (1967) Reaction sequence of blood coagulation. Nature 215, 1201-1202

Hemker HC, and Lindhout T (1984) A clotting scheme for 1984. Nouv Rev Fr Hematol 26, 227-231

Hemker HC (1983) Handbook of synthetic substrates for the coagulation and fibrinolytic system. Boston: Martinus Nijhoff p. 31

Henschen A, and McDonagh J (1986) Fibrinogen, fibrin and factor XIII. in Blood coagulation, (Zwaal RFA and Hemker HC, Eds), Elsevier, Amsterdam, pp. 171-241

Higgins DL, and Mann KG (1983) The interaction of bovine factor V and factor V-derived peptides with phospholipid vesicles. $J$ Biol Chem 258, 6503-6508 
Hill KA, Kroon LM, and Castellino FJ (1987) The effect of divalent cations on the amidolytic activity of bovine plasma activated protein $\mathrm{C}$ and des-1-41-light chain activated protein $\mathrm{C}$. $J$ Biol Chem 262, 9581-9586

Holmsen H, and Weiss HJ (1979) Secratable storage pools in platelets. Ann Rev Med 30, 119-134

Hoskins J, Norman DK, Beckmann RJ, and Long GL (1987) Cloning and characterization of human liver cDNA encoding a protein S precursor. Proc Natl Acad Sci USA 84, 349-353

Hoyer LW (1981) The factor VIII complex: Structure and function. Blood 58, 1-13

Ikeda K, and Stenflo J (1985) A radioimmunoassay for protein C. Thromb Res 39, 297-306

Jackson CM, and Nemerson Y (1980) Blood coagulation. Ann Rev Biochem 49, 765-811

Jane SM, Hau L, and Salem HH (1991) Regulation of activated protein C by factor Xa. Blood Coagulation Fibrinolysis 2, 723-729

Jenny RJ, Pittman DD, Toole JJ, Kriz RW, Aldape RA, Hewich RM, Kaufman RJ, and Mann KG (1987) Complete cDNA and derived amino acid sequence of human factor V. Proc Natl Acad Sci USA 84, 4846-4850

Johnson AE, Esmon NL, Laue TM, and Esmon CT (1983) Structural changes required for activation of protein $\mathrm{C}$ are induced by $\mathrm{Ca}$ binding to a high affinity site that does not contain $\gamma$-carboxyglutamic acid $J$ Biol Chem 258,5554-5560

Josso F, and Prou-Wartelle O (1965) Interaction of tissue factor and factor VII at the earliest phase of coagulation. Thromb Diath Haemorrh Suppl 17, 35-44

Kahn MJP, and Hemker HC (1972) Studies on blood coagulation factor V. V. Changes of molecular weght accompanying activation of factor $\mathrm{V}$ by thrombin and the procoagulant protein of Russell's viper venom. Thromb Diath Haemorrh 27, 25-32

Kalafatis M, Jenny RJ, and Mann KG (1990) Identification and characterization of a phospholipidbinding site of bovine factor Va. J Biol Chem 265, 21580-21589

Kane $\mathrm{WH}_{3}$ and Majerus PW (1981) Purification and characterization of human coagulation factor V. $\checkmark$ Biol Chem 256, 1002-1007

Kane WH, and Davie EW (1986) Cloning of a cDNA coding for human factor V, a blood coagulation factor homologous to factor VIII and ceruloplasmin. Proc Natl Acad Sci USA 83, 68006804

Kane WH, Ichinose A, Hagen FS, and Davie EW (1987) Cloning of cDNAs coding for the heavy chain region and conecting region of human factor $\mathrm{V}$, a blood coagulation factor with four types of internal repeats. Biochemistry 26, 6508-6514 
Katzmann JA, Nesheim ME, Hibbard LS, and Mann KG (1981) Isolation of functional human coagulation factor V by using a hybridoma antibody. Proc Natl Acad Sci USA 78, 162-166

Kisiel W, Canfield WM, Ericsson LH, and Davie EW (1977) Anticoagulant properties of bovine plasma protein $\mathrm{C}$ following activation by thrombin. Biochemistry 16, 5824-5831

Kisiel W, Ericsson LH, and Davie EW (1976) Proteolytic activation of protein C from bovine plasma. Biochemistry 16, 4893-4900

Kisiel W, Choi E, and Kondo S (1987a) Isolation of a protein C activator from southern copperhead venom. Biochem Biophys Res Comm 143, 917-922

Kisiel W, Kondo S, Smith KJ, McMullen BA, and Smith LF (1987b) Characterization of a protein C activator from Agkistrodon contortrix contortrix venom. J Biol Chem 262, 12607-12613

Kisiel W (1979) Human plasma protein C. Isolation, characterization and mechanism of activation by $\alpha$-thrombin. $J$ Clin Invest $64,761-769$

Kisiel W (1979)) Molecular properties of the factor V activating enzyme from Russell's Viper Venom. $J$ Biol Chem 254, 12230-12234

Klein JD, and Walker FJ (1986) Purification of a protein C activator from the venom of the southern copperhead snake (Agkistrodon contortrix contortrix). Biochemistry 25, 4175-4179

Koedam JA, Meijers JCM, Sixma JJ, and Bouma BN (1988) Inactivation of human factor VIII by activated protein $\mathrm{C}$. Cofactor activity of protein $\mathrm{S}$ and protective effect of von Willebrand factor. $J$ Clin Invest 82, 1236-1243

Kop JMM, Willems GM, and Hermens WT (1989) Binding of coagulation factor $\mathrm{V}$ to planar phospholipid double layers. J Colloid Interface Sci 133, 369-376

Krieg UC, Isaacs BS, Yemul SS, Esmon CT, Bailey H, and Johnson AE (1987) Interaction of blood coagulation factor $\mathrm{Va}$ with phospholipid vesicles examined by using lipophilic photoreagents. Biochemistry 26, 103-109

Krishnaswamy S, and Mann K.G (1988) The binding of factor Va to phospholipid vesicles. J Biol Chem 263, 5714-5723

Krishnaswamy S, Jones KC, and Mann KG (1988) Prothrombinase complex assembly. Kinetic mechanism of enzyme assembly on phospholipid vesicles. $J$ Biol Chem 263, 3823-3834

Laemmli UK (1970) Cleavage of the structural proteins of the head of the bacteriophage T4. Nature 227, 680-685 
Lecompte MF, Krishnaswamy S, Mann KG, Nesheim ME, and Gitler C (1987) Membrane penetration of bovine factor $\mathrm{V}$ and $\mathrm{Va}$ detected by labelling with 5 -iodonaphtalene-1-azide. $J$ Biol Chem 262, 1935-1937

Liebman HA, Furie BC, and Furie B (1987) The factor IX-phospholipid binding site is required for calcium-dependent activation of factor IX by factor XIa. I Biol Chem 262, 7605-7612

Lindhout T, Govers-Riemșlag JWP, van de Waart P, Hemker HC, and Rosing J (1982) Factor Vafactor $\mathrm{Xa}$ interactions. Effects of phospholipid vesicles of varying composition. Biochemistry 21, 5494-5502

Lowry OH, Rosenbrough NJ, Farr AL, and Randall RJ (1951).J Biol Chem 193, 265-275

Lundwall A, Dackowski W, Cohen E, Shaffer M, Mahr A, Dahlbăck B, Stenflo J, and Wydro R (1986) Isolation and sequence of the cDNA for human protein S, a regulator of blood coagulation. Proc Nall Acad Sci USA 83, 6716-6720

Malm J, Persson U, and Dahlbăck B (1987) Inhibition of human vitamin-K-dependent protein-Scofactor activity by a monoclonal antibody specific for $\mathrm{Ca}^{2+}$-dependent epitope Eur $J$ Biochem $\mathbf{1 6 5}$, $39-45$

Mammen EF, Thomas WR, and Seegers WH (1960) Activation of purified prothrombin to autoprothrombin I or autoprothrombin II (platelet cofactor II or autoprothrombin II-A). Thromb Diath 5, 218-249

Mann KG, Nesheim ME, Church WR, Haley P, and Krishnaswamy S (1990) Surface-dependent reactions of the vitamin K-dependent enzyme complexes. Blood 76, 1-16

Marciniak. E (1970) Coagulation inhibitor elicited by thrombin. Science 170, 452-453

Marlar RA, and Griffin JH (1980) Deficiency of protein C inhibitor in combined factor V/VIII deficiency desease. $J$ Clin Invest 66, 1186-1189

Marlar RA, Kleis AJ, and Griffin JH (1982) Mechanism of action of human Activated Protein C, a thrombin-dependent anticoagulant enzyme. Blood 59, 1067-1072

Martinoli JL, and Stocker K (1986) Fast functional protein C assay using Protac, a novel protein C activator. Thromb Res 43, 253-246

MeMullen BA, Fujikawa K, and Kisiel W (1989) Primary structure of a protein C activator from Agkistrodon contortrix contortrix venom. Biochemistry 28, 674-679

Meier J, Adler C, and Stocker K (1988). The isoelectric focusing of Protac, the protein C activator from copperhead (Agkistrodon contortrix contortrix) venom: a note on experimental problems. Toxicon 26, 218-221 
Mesters R, Houghton R, and Griffin JH (1991) Identification of a sequence of human activated protein C (residues 390-404) essential for its anticoagulant activity. J Biol Chem 266, 24514-24519

Mitchell CA, Kelemen SM, and Salem HH (1988) The anticoagulant properties of a modified form of protein S. Thrombosis and Haemostasis 60, 298-304

Mitchell CA, Jane SM, and Salem HH (1988) Inhibition of the anticoagulant activity of protein S by prothrombin. J Clin Invest 82, 2142-2147

Monkovic DD, and Tracy PB (1990) Activation of human factor V by factor Xa and thrombin. Biochemistry 29, 1118- 1128

Nakagaki T, Foster DC, Berkner KL, and Kisiel W (1991) Initiation of the extrinsic pathway of blood coagulation: Evidence for the tissue factor dependent atoactivation of human coagulation factor VIl. Biochemistry 30, 10819-10824

Nakagaki T, Kazim AL, and Kisiel W (1990) Isolation and characterization of a protein C activator form tropical moccasin venom. Thromb Res 58, 593-602

Nelsestuen GL, and Broderius $\mathrm{M}$ (1977) Interaction of prothrombin and blood-clotting factor $\mathrm{X}$ with membranes of varying composition. Biochemistry 16, 4172-4177.

Nelsestuen GL, Kisiel W, and DiScipio RG (1978) Interaction of vitamin K-dependent proteins with membranes. Biochemistry 17, 2134-2138

Nelsestuen GL (1976) Role of $\gamma$-carboxyglutamic acid. An unusual transition required for calciumdependent binding of prothrombin to phospholipid. J Biol Chem 251, 5648-5656

Nesheim, ME, Foster WB, Heywick R, and Mann KG (1984) Characterization of factor V activation intermediates. $J$ Biol Chem 259, 3187-3196.

Nesheim ME, Canfield WM, Kisiel W, and Mann KG (1982) Studies of the capacity of factor Xa to protect factor Va from inactivation by activated protein C. J Biol Chem 257, 1443-1447

Nesheim ME, Taswell JB, and Mann KG (1979) The contribution of bovine factor $\mathrm{V}$ and factor Va to the activity of prothrombinase. $J$ Biol Chem 254, 10952-10962.

Nesheim ME, Myrmel KH, Hibbard L, and Mann KG (1979) Isolation and characterization of single chain bovine factor V.J Biol Chem 254, 508-517

Nesheim ME, and Mann KG (1979) Thrombin-catalyzed activation of single chain bovine factor V. J Biol Chem 254, 1326-1334

Novotny WF, Girard TJ, Miletich JP, and Broze GJ (1989) Purification and characterization of the lipoprotein-associated coagulation inhibitor from human plasma. J Biol Chem 264, 18832-18837 
Odegaard B, and Mann KG (1987) Proteolysis of factor Va by factor Xa and activated protein C. I Biol Chem 262, 11233-11238

Ortel TL, Devore-Carter D, Quin-Allen MA, and Kane WH (1992) Deletion analysis of recombinant human factor V. Evidence for a phosphatidylserine binding site in the second C-type domain. J Biol Chem 267, 4189-4198

Orthner C, Bhattacharya P, and Strickland DK (1988) Characterization of a protein C activator from the venom of Agkistrodon contortrix contortrix. Biochemistry 27, 2558-2564

Owen WG, Esmon CT, and Jackson CM (1974) The conversion of prothrombin to thrombin. I. Characterization of the reaction products formed during the activation of bovine prothrombin. $J$ Biol Chem 249, 594-605

Pieters J, Hemker HC, and Lindhout T (1989) In situ generated thrombin is the only enzyme that effectively activates factor VIII and factor V in thromboplastin-activated plasma. Blood 74, 10211024

Pletcher CH, and Nelsestuen GL (1982) The rate-determining step of the heparin-catalyzed antithrombin/thrombin reaction is independent of thrombin. J Biol Chem 257, 5342-5345

Poort SR, Deutz-Terlouw PP, van Wijngaarden A, and Bertina RM (1988) Immunoradiometric assays for the $\mathrm{Ca}(\mathrm{II})$-dependent and $\mathrm{Ca}(\mathrm{II})$-independent conformation of human protein $\mathrm{C}$. Thrombosis Res 52, 87-100

Prendergast FG, and Mann KG (1977) Differentiation of metal ion-induced transition of prothrombin fragment 1. J Biol Chem 252, 840-850

Pusey ML, Mayer LD, Wei GJ, Bloomfield VA, and Nelsestuen GL (1982) Kinetic and hydrodynamic analysis of blood clotting factor V-membrane binding. Biochemistry 21, 5262-5269

Pusey ML, and Nelsestuen GL (1984) Membrane binding properties of blood coagulation factor $\mathrm{V}$ and derived peptides. Biochemistry 23, 6202-6210

Rao LVM, and Rapaport SI (1987) Studies of a mechanism inhibiting the initiation of the extrinsic pathway of coagulation. Blood $69,645-651$

Rapaport SI (1991) The extrinsic pathway inhibitor: A regulator of tissue factor-dependent blood coagulation. Thromb Haemost 66, 6-15

Resnick RM, and Nelsestuen GL (1980) Prothrombin-membrane interaction. Effects of ionic strength, $\mathrm{pH}$, and temperature. Biochemistry 19, 3028-3033

Rosing J, Tans G, Govers-Riemslag JWP, Zwaal RFA, and Hemker HC (1980) The role of phospholipids and factor $\mathrm{Va}$ in the prothrombinase complex. J Biol Chem 255, 274-283 
Rosing J, and Tans G (1988) Meizothrombin, a major product of factor Xa-catalyzed prothrombin activation. Thromb Haemost 60, 355-360

Rosing J, Speijer H, and Zwaal RFA (1988) Prothrombin activation on phospholipid membranes with positive electrostatic potential. Biochemistry 27, 8-11

Rosing J, and Tans G (1988) in Coagulation \& Lipids, (Zwaal RFA, Ed) pp. 159-187, USA, CRC Press Inc, Boca Raton, Florida

Rosing J, Bakker HM, Thomassen MCLGD, Hemker HC, and Tans G (1993) Characterization of two forms of human factor Va with different cofactor activities. I Biol Chem 268, 21130-2.1136

Sadykov ES, Barabantshykova NA, Shuvalova I, and Yukelson LY (1985) The venom of snake Tchitomordnic Agkistrodon halys halys. V. Components with anticoagulant activity. Chim Prirodn Soed (Chem Nat Prod) 6 851:852

Sala N, Owen WG, and Collen D (1984) A functional assay of protein C in human plasma. Blood $63,671-675$

Schägger H, and von Jagow G (1987) Tricine-sodium dodecyl sulfate-polyacrylamide gel electrophoresis for the separation of proteins in the range from 1 to $100 \mathrm{kDa}$. Anal Biochem 166, 368-379

Schiffman S, Theodor I, and Rapaport SI (1969) Separation from Russell's viper venom of one fraction reacting with factor $\mathrm{X}$ and another reacting, with factor $\mathrm{V}$. Biochemistry 8, 1397-1405

Schwarz HP, Fischer M, Hopmeier P, Batard MA, and Griffin JH (1984) Plasma protein S deficiency in familial thrombotic disease. Blood 64, 1297-1300

Seegers WH, Novoa E, Henry RL, and Hassouna HI (1976) Relationship of 'new' vitamin Kdependent protein $\mathrm{C}$ and 'old' autoprothrombin II-A. Thromb Res 8, 543-552

Seligsohn U, Berger A, Abend M, Rubin L, Attias D, Zivelin A, and Rapaport SI (1984) Homozygous protein $\mathrm{C}$ deficiency manifested bymassive venous thrombosis in the newborn. New Eng! JMed 310, 559-562

Smith RL (1973) Titration of activated bovine factor X. J'Biol Chem 248, 2418-2423

Solymoss S, Tucker MM, and Tracy PB (1988) Kinetics of inactivation of membrane-bound factor $\mathrm{Va}$ by activated protein C. Protein $\mathrm{S}$ modulates factor Xa protection. J Biol Chem 263, 14884-14890

Steiner SA, Amphlett GW, and Castellino FJ (1980) Stimulation of the amidase and esterase activity of activated bovine plasma Protein C by monovalent cations. Biochem Biophys Res Comm 94, 340347 
Steiner SA, and Castellino FJ (1982) Kinetic studies of the role of monovalent cations in the amidolytic activity of activated bovine plasma protein C. Biochemistry 21, 4609-4614

Steiner SA, and Castellino FJ (1985) Effect of monovalent cations on the pre-steady-state kinetic parameters of the plasma protease bovine activated protein C. Biochemistry 24, 1136-1141

Stenflo J, and Suttie (1977) Vitamin K-dependent formation of $\gamma$-carboxy glutamic acid. Ann Rev Biochem 46, 157-172

Stenflo J (1976) A new vitamin K-dependent protein. Purification from bovine plasma and preliminary characterization. $J$ Biol Chem 251, 355-363

Stern D, Brett J, Harris K, and Nawroth P (1986) Participation of endothelial cells in the protein C Protein S anticoagulant Pathway: The synthesis and release of protein S. J Cell Biol 102, 1971-1978

Stocker K, Fischer H, Meier J, Brogli M, and Svendsen L (1987) Characterization of the protein C activator from the venom of the southern copperhead (Agkistrodon contortrix contortrix) snake. Toxicon 25, 239-252

Strukova SM, Koan AE, Tara A, and Aaviksaar A (1989) Anticoagulant effect of the protease from. Agkistrodon venom mediated by protein $\mathrm{C}$ activation in rats. Thromb Res 55, 149-153

Suttie JW (1985) Vitamin K-dependent carboxylase. Ann Rev Bioch 54, 459-477

Suzuki K, Stenflo J, Dahlbăck B, and Teodorsson B (1983) Inactivation of human coagulation factor $\mathrm{V}$ by activated protein C. J Biol Chem 258, 1914-1920

Suzuki K, Dahibäck B, and Stenflo J (1982) Thrombin-catalyzed activation of human coagulation factor V. J Biol Chem 257, 6556-6564

Tans G, Janssen-Claessen T, Hemker HC, Zwaal RFA, and Rosing J (1991) Meizothrombin formation during factor Xa-catalyzed prothrombin activation. Formation in a purified system and in plasma. J Biol Chem 266, 21864-21873

Tans G, Rosing J, Thomassen MCLGD, Heeb MJ, Zwaal RFA, and Griffin JH (1991) Comparison of anticoagulant and procoagulant activities of stimulated platelets and platelet-derived microparticles, Blood 77, 2641-2648

Tans G, Janssen-Claessen T, and Rosing J (1989) Amidolytic detection of prothrombin activation products after SDS-gel electrophoresis. Thromb Haemostas 61, 386-391.

Tokunaga F, Nagasawa K, Tamura S, Miyata T, Iwanaga S, and Kisiel W (1988) The factor Vactivating enzyme (RVV-V) from Russell's viper venom. Identification of isoproteins $R V V-V \alpha,-V \beta$, and $-\mathrm{V} \gamma$ and their complete aminoacid sequences. J. Biol Chem 263, 17471-17481 
Tollefsen DM, Majerus DW, and Blank MK (1982) Heparin cofactor II. Purification and properties of a heparin-dependent inhibitor of thrombin in human plasma. J Biol Chem 257, 2162-2169

Toole JJ, Knopf JL, Wozney JM, Saltzman LA, Buecker JL, Pitman DD, Kaufman RJ, Brown E, Shoemaker C, Orr EC, Amphlett GW, Foster WB, Coe ML, Knutson GJ, Fass DN, and Hewick (1984) Molecular cloning of a cDNA encoding human antihaemophilic factor. Nature 312, 342-347

Tracy PB, Eide LL, Bowie EJW, and Mann KG (1982) Radioimmunoassay of factor V in human plasma and platelets. Blood 60, 59-63

Travis J, and Salvesen GS (1983) Human plasma protease inhibitors. Ann Rev Biochem 52, 655-709

Tucker MM, Foster WB, Katzmann JA, and Mann KG (1983) A monoclonal antibody which inhibits the factor Va:factor Xa interaction. J Biol Chem 258, 1210-1214

Tulinsky A, Park CH, and Skrzypaczak-Jakun E (1988) Structure of prothrombin fragment I. Refined at $2.8 \AA$ resolution. JMol Biol 202, 885-901

van de Waart P, Bruls H, Hemker HC, and Lindhout T (1983) Interaction of bovine blood clotting factor Va and its subunits with phospholipid vesicles. Biochemistry 22, 2427-2432

van de Waart P, Bruls H, Hemker HC, and Lindhout T (1984) Functional properties of factor Va subunits after proteolytic alterations by activated protein C. Biochim Biophys Acta 799, 38-44

van Dieijen G, Tans G, Rosing J, and Hemker HC (1981) The role of phospholipid and factor VIIla in the activation of bovine factor X. J Biol Chem 256, 3433-3442

van Dieijen G, van Rijn JLML, Govers-Riemslag JWP, Hemker HC, and Rosing J (1985) Assembly of the intrinsic factor $\mathrm{X}$ activating complex - Interactions between factor IXa, factor VIIII and phospholipid. Thromb Haemost 53, 396-400

van Rijn JML, Govers-Riemslag JWP, Zwaal RFA, and Rosing J (1984) Kinetic studies of prothrombin activation: Effect of factor $\mathrm{Va}$ and phospholipids on the formation of the enzymesubstrate complex. Biochemistry 23, 4557-4564

Vehar GA, and Davie EW (1980) Preparation and properties of bovine factor VIII (antihemophilic factor). Biochemistry 19, 401-410

Vehar GA, Keyt B, Eaton D, Rodriquez H, O'Brien DP, Rotblat F, Oppermann H, Keck R, Wood WI, Harkins RN, Tuddenham EGD, Lawn RM, and Capon DJ (1984) Structure of human factor VIII. Nature 312, 337-342

Wakabayashi K, Sakata Y, and Aoki N (1986) Conformation-specific monoclonal antibodies to the calcium-induced structure of protein C, J Biol Chem 261, 11097-11105 
Walker FJ, Sexon PW, and Esmon CT (1979) The inhibition of blood coagulation by activated protein $\mathrm{C}$ through the selective inactivation of activated factor V. Biochim Biophys Acta 571, 333342

Walker FJ, Chavin SI, and Fay PJ (1987) Inactivation of factor VIII by activated protein C and protein S. Arch Biochem Biophys 252, 322-328

Walker FJ, Scandella D, and Fay PJ (1990) Identification of the binding site for activated protein C on the light chain of factors V and VIII. $J$ Biol Chem 265, 1484-1489I

Walker FJ (1980) Regulation of activated Protein C by a new protein: A possible function for bovine protein S.J Biol Chem 255, 5521-5524

Walker FJ (1981) Regulation of activated protein C by protein $\mathrm{S}$ : The role of phospholipid in factor Va inactivation. I Biol Chem 256, 11128-11131

Walker FJ (1986) Identification of a new protein involved in the regulation of the anticoagulant activity of activated protein C. J Biol Chem 261, 10941-10944

Walker FJ (1992) Protein S and thrombotic disease. Proc Soc Exp Biol Med 200, 285-295

Wilson DB, Salem HH, Mruk JS, Maruyama I, and Majerus PW (1983) Biosynthesis of coagulation factor $\mathrm{V}$ by a human hepatocellular carcinoma cell line. $J$ Clin Invest 73, 654-658

Yamamoto M, Nakagaki T, and Kisiel W (1992) Tissue Factor-dependent autoactivation of human blood coagulation factor VII. J Biol Chem 267, 19089-19094

Yukelson LYa, Tans G, Thomassen MCLGD, Hemker HC, and Rosing, J (1991) Procoagulant activities in venoms from central asian snakes. Toxicon 29, 491-502 


\section{ABBREVIATIONS and GLOSSARY}

APC

Apparent value

BSA

Chromozym-TH

DEAE

(DO)PC

(DO)PS

EDTA

FPLC

HEPES

I-258 I

$k_{\text {cat }}$

$k_{\mathrm{cat}} / K_{\mathrm{m}}$

$K_{\mathrm{d}}$

$K_{\mathrm{i}}$

$K_{\mathrm{m}}$

$\mathrm{M}_{\mathrm{T}}$

PMSF

$\mathrm{p}-\mathrm{NPGB}$

PPACK

QAE

RVV-V

RVV-X

S2222

Activated Protein C.

Quantity that is constant only while specified concentrations are held constant. bovine serum albumin

$\mathrm{N}$-Tosyl-L-glycyl-L-prolyl-L-arginine-p-nitroanilide

diethylaminoethyl: Chemical group used in anion-exchange chromatography

(1,2-dioleoyl)-sn-glycero-3-phosphocholine

(1,2-Dioleoyl)-sn-glycero-3-phosphoserine

ethylenediaminetetraacetic acid

fast liquid protein chromatography

hydroxyethylpiperazineethanesulfonic acid: Good buffer, $\mathrm{p} K_{\mathrm{a}}=7.5$.

$\mathrm{N}^{\alpha}$-dansyl-(p-guanidino)-phenylalanine-piperidinc hydrochloride: Reversible inhibitor of thrombin.

Catalytic constant: limiting rate divided by total enzyme concentration: also turnover number.

Catalytic efficiency: The $k_{\mathrm{cat}} / K_{\mathrm{m}}$ determines the specificity for competing substrates, and sets a lower limit on the rate constant for the association of enzyme and substrate.

Dissociation constant: the free concentration of a substance which result in half maximal binding

Inhibitor constant: inhibitor concentration at which the rate of an enzyme catalyzed reaction is half of the rate without inhibitor.

Michaelis constant: substrate concentration at which the rate of an enzyme catalyzed reaction is half of the limiting rate.

Relative molecular weight

Phenylmethanesulfonyl fluoride

p-nitrophenyl-p'-guanidino-benzoate hydrochloride: Suicide substrate used for active site titration of trypsin-like enzymes.

D-phenylalanyl-L-prolyl-L-arginine chloromethyl ketone: Irreversible inhibitor of serine proteases with high affinity for thrombin $\left(K_{\mathrm{i}}^{\text {thrombin }}=2.5 \mathrm{nM}\right)$.

Chloromethylketones alkylate the active site histidine of the catalytic triad Ser-HisAsp.

Quaternary aminoethyl: Chemical group used in anion-exchange chromatography purified factor V activator from Russell's viper venom (Schiffiman et al', 1969; Tokunaga et al'., 1988)

purified factor $X$ activator from Russell's viper venom (Schiffman et al', 1969)

H-D-isoleucyl-L-glutamyl-L-glycyl-L-arginine-p-nitroanilide dihydrochloride 
$\$ 2238$

$\mathrm{S} 2251$

$\mathrm{S} 2288$

\$2302

$\$ 2337$

\$2366

\$2765

SDS

SDS-PAGE

Tris

$V_{\max }$
H-D-phenylalanyl-L-pipecolyl-L-arginine-p-nitroanilide dihydrochloride: Chromogenic substrate used for thrombin.

H-D-valinyl-L-leucyl-L-lysine-p-nitroanilide dihydrochloride H-D-isoleucyl-L-prolyl-L-arginine-p-nitroanilide dihydrochloride H-D-Prolyl-L-phenylalanyl-L-arginine-p-nitroanilide dihydrochloride: Chromogenic substrate used for kallikrein and factor XIIa.

$\mathrm{N}$-benzoyl-L-isoleucyl-L-glutamyl-piperidyl-glycyl-L-arginine-p-nitoanilide hydrochloride: Chromogenic substrate used for factor $\mathrm{X}_{\mathrm{a}}$.

L-pyroglutamyl-L-prolyl-L-arginine-p-nitroanilide hydrochloride: Chromogenic substrate used for activated protein $C$ (APC).

$\mathrm{N}^{\alpha}$-Benzylcarbonyl-D-arginyl-L-glycyl-L-arginine-p-nitroanilide hydrochloride sodium dodecyl sulfate

polyacrylamide gel electrophoresis in the presence of SDS

Tris(hydroxymethyl)amino-methane: $B$ uffer $\mathrm{p} K_{\mathrm{a}}=8.3$.

Limiting rate: rate approached by an enzyme-catalyzed reaction when the substrate concentrations become very large. 


\section{Dankwoord}

Dit proefschrift is tot stand gekomen met behulp van een groot aantal mensen. Ik wil dan ook mijn erkentelijkheid uitspreken voor een ieder die, direct of indirect, heeft bijgedragen.

Guido en Jan ben ik zeer erkentelijk voor de manier waarop zij het onderzoek hebben begeleid en voor de hulp bij het schrijven van dit proefschrift.

Ik wil mijn promotor Prof. Coen Hemker bedanken voor de gelegenheid die hij mij heeft gegeven om in zijn laboratorium dit onderzoek te verrichten.

Truus wil ik in het bijzonder bedanken, samen hebben we heel wat uren achter de waterbaden doorgebracht. Jouw inbreng in het onderzoek is cruciaal geweest. Ook wil ik Stella bedanken die het laatste jaar mijn rechterhand was en ook als paranimf mij terzijde wil staan.

De andere labgenoten Rita, José, Jo, Ron, Pieter en Theo hebben voor de prettige werksfeer in het lab gezorgd. Ook Simone, Marion, Cecile, Khaled, Marjo Birgit, Jos en Ana wil ik bedanken voor de gezelligheid binnen en buiten het lab. Harry, Han en Peter waren prettige collega's waarvan ik, naast de geneugten des levens. eten drinken en stappen, vooral ook veel van de stolling heb geleerd.

Of course I like to thank Hu Kai for the pleasant times we had together and for the delicious dishes you made for us.

Op het labje van Chris was ik (bijna) altijd welkom om van de FPLC gebruik te maken. Door Cecile werd ik ingewijd in de geheimen van het apparaat.

Ik zou bijna de bevrouwing van het (de) sekretaria(a)t(en) vergeten, op Mariet. Gertie en Trees kon altijd een beroep gedaan worden.

Prof. Geraedts, Prof Mannucci, Prof. Kuipers, Dr. van Mourik en Dr. Karly Hamulyak ben ik erkentelijk voor de bereidwilligheid om in de beoordelingscommissie plaats te nemen.

Verder ben ik Jan-Willem. Niek en Alie dankbaar voor hun waardevolle bijdrage aan het tot stand komen van dit proefschrift. Peter bedankt dat je als paranimf bij mijn promotie wilt optreden.

Als laatste bedank ik mijn ouders, grootouders en schoonouders die altijd zeer veel belangstelling toonden voor mijn studie en promotie onderzoek. Helaas hebben mijn schoonvader, opa en oma dit niet meer mee kunnen maken. Marijke bedankt!

Ik heb een plezierige tijd in Maasticht doorgebracht, bepaalde aspecten zal ik zeker missen. Maastricht en z'n prachtige omgeving zullen we dan ook regelmatig aandoen.

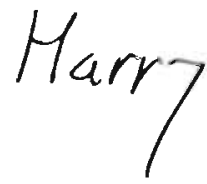




\section{Curriculum vitae}

Harty Bakker werd geboren op 26 februari 1958 te Krimpen aan den IJssel. Hij behaalde het MAVO diploma in 1975 aan de 'Willem van Oranje' MAVO te Hengelo. In hetzelfde jaar begon hij de analisten opleiding aan de School voor Laboratorium Personeel in Hengelo, die in 1979 werd afgesloten met het HBO-A diploma Klinische Chemie. In dat jaar startte hij zijn studie Biologie aan de Rijksuniversiteit Groningen. In 1987 werd het doctoraal diploma met als specialisatie Moleculaire Genetica behaald. Zijn twee doctoraalvakken waren Moleculaire Genetica en Fysiologische Chemie. Tot december 1988 was hij werkzaam bij de vakgroep Fysiologische Chemie van de Rijksuniversiteit Groningen. Daarna trad hij in dienst als Assistent in Opleiding bij de vakgroep Biochemie van de Rijksuniversiteit Limburg, alwaar hij het onderzoek verrichtte dat heeft geleid tot dit proefschrift. 
